\title{
Baker Cave, Val Verde County, Texas: The 1976 Excavations
}

\section{Mary Frances Chadderon}

Center for Archaeological Research

Follow this and additional works at: https://scholarworks.sfasu.edu/ita

Part of the American Material Culture Commons, Archaeological Anthropology Commons, Environmental Studies Commons, Other American Studies Commons, Other Arts and Humanities Commons, Other History of Art, Architecture, and Archaeology Commons, and the United States History Commons

Tell us how this article helped you.

This Article is brought to you for free and open access by the Center for Regional Heritage Research at SFA ScholarWorks. It has been accepted for inclusion in Index of Texas Archaeology: Open Access Gray Literature from the Lone Star State by an authorized editor of SFA ScholarWorks. For more information, please contact cdsscholarworks@sfasu.edu. 


\section{Baker Cave, Val Verde County, Texas: The 1976 Excavations}

Creative Commons License

(c) (i) (8)

This work is licensed under a Creative Commons Attribution-NonCommercial 4.0 International License 

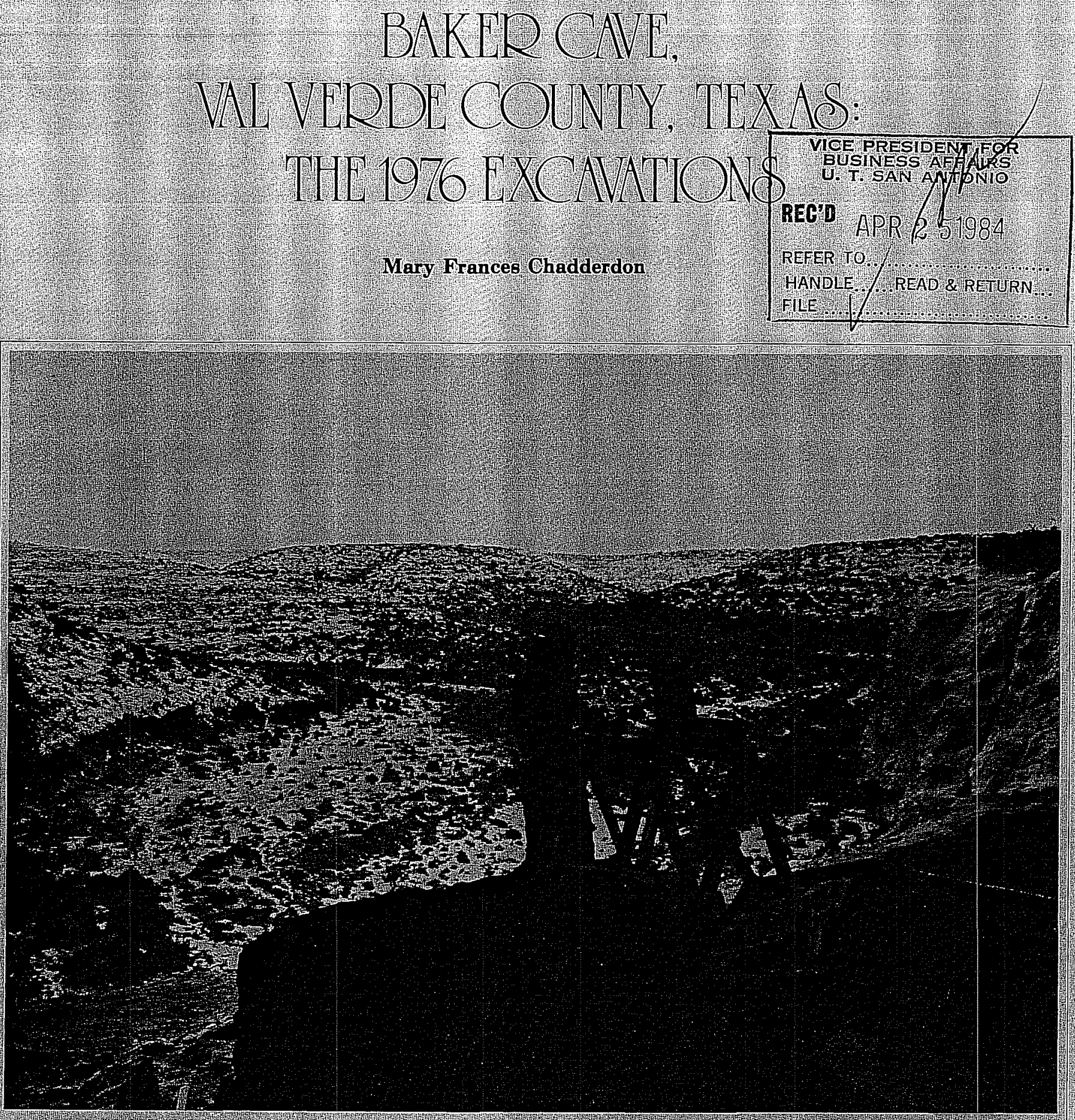

Center for Archaeological Research

The University of lexas at San Antonio

Special Report No 18 


\title{
Center for Archaeological Research
}

\section{The University of Texas at San Antonio}

\section{5}

\author{
Thomas R. Hester, Director
}

\section{Special Reports}

Publications dealing with the archaeology of Texas and Mesoamerica.

No. 1 (1975) Some Aspects of Late Prehistoric and Protohistoric Archaeology in Southern Texas. By Thomas R. Hester and T. C. Hill, Jr. Photocopy reprints available. $\$ 7.00+.39$ tax for Texas residents.

No. 2 (1976) The Texas Archaic: A Symposium. Edited by Thomas R. Hester. Photocopy reprints available. $\$ 7.50+.41$ tax for Texas residents.

No. 3 (1976) Papers on Paleo-Indian Archaeology in Texas. Papers by T. R. Hester and W. W. Birmingham. Photocopy reprints available. $\$ 7.00+.39$ tax for Texas residents.

No. 4

(1976) Maya Lithic Studies: Papers from the 1976 Belize Field Symposium. Edited by T. R. Hester and Norman Hammond. Reprinted 1982. $\$ 9.00+.50$ tax for Texas residents.

No. 5 (1977) Hop Hi11: Culture and Climatic Change in Central Texas. By Joel Gunn and Royce Mahula. Photocopy reprints available. $\$ 18.00+.99$ tax for Texas residents.

No. 6

(1978) Volume 1: Studies in the Archaeology of Chaparrosa Ranch. Background to the Archaeology of Chaparrosa Ranch. By Thomas $R$. Hester. Photocopy reprints available. $\$ 4.00+.22$ tax for Texas residents.

Volume 2: Studies in the Archaeology of Chaparrosa Ranch. The Mariposa Site: A Late Prehistoric Site on the Rio Grande Plain of Texas. By John Montgomery. $\$ 8.00+.44$ tax for Texas residents.

No. 7

The Study of Biosilica: Reconstructing the Paleoenvironment of the Central Coastal Plain of Texas. By Ralph L. Robinson. Not available at this time.

No. 8

(1979) The Lithic Artifacts of Indians at the Spanish Colonial Missions, San Antonio, Texas. By Daniel E. Fox. $\$ 5.00+.28$ tax for Texas residents.

No. 9

(1980) Papers on the Prehistory of Northeastern Mexico and Texas. Edited by Jeremiah F. Epstein, Thomas R. Hester, and Carol Graves, $\$ 8.00+.44$ tax for Texas residents.

No. 10

(1980) Excavations at the Alamo Shrine (San Antonio de Valero), 1977. By Jack 0 . Eaton. $\$ 7.00+.39$ tax for Texas residents.

No. 11

(1980) Papers on the Archaeology of the Texas Coast. Edited by Lymn Highley and Thomas R. Hester. $\$ 7.00+.39$ tax for Texas residents.

No. 12

(1982) Eagle Hi11: A Late Quaternary Upland Site in Western Louisiana. By Joel Gunn and David 0. Brown. Write to the Center for information:

No, 13 (1983) Volume 1: 1976 Baker Cave Project. Baker Cave, Val Verde County, Texas: The 1976 Excavations. By Mary Frances Chadderdon. $\$ 12.00+.66$ for Texas residents. 
BAKER CAVE, VAL VERDE COUNTY, TEXAS:

THE 1976 EXCAVATIONS

Mary Frances Chadderdon

Center for Archaeological Research ${ }^{\circledR}$ The University of Texas at San Antonio Special Report, No. 13 
for Tom

sine qua non

Volume 1: 1976 Baker Cave Project 
LIST OF FIGURES ................... . . . . . . . . .

LIST OF TABLES ......................... . . . . . . .

FOREWORD (Thomas R. Hester) .............. iv

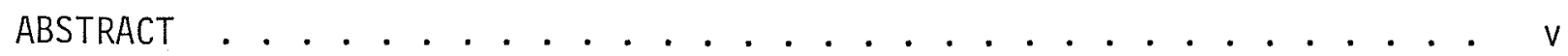

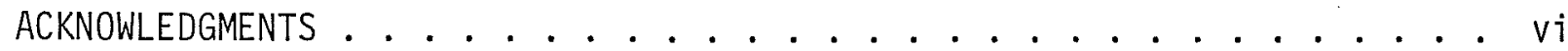

SPECIAL ACKNOWLEDGMENT ....................... vi

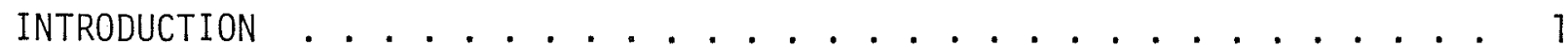

DISCUSSION OF THE REGION ................ 3

Climate and Topography .............. 3

Vegetation .................. 5

Fauna ................... 6

Previous Archaeological Research . . . . . . . . . . . 8

DESCRIPTION OF THE SITE . . . . . . . . . . . . . . 9

Physical Characteristics . . . . . . . . . . . . 9 9

Prior Excavations at the Site . . . . . . . . . . . 9

Extent of Sampling . . . . . . . . . . . . . . . 14

RESEARCH DESIGN ........................ 14

Background ................... . . 14

objectives .................. . . 17

METHODOLOGY FOR THE 1976 EXCAVATIONS ............. 18

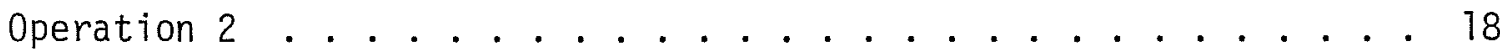

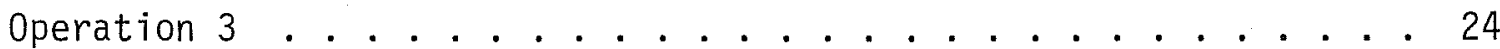

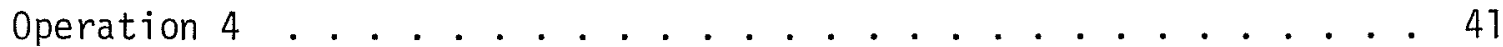

Extent of Sampling . . . . . . . . . . . . . 41

DESCRIPTION OF THE ARTIFACTS .................. 45

Lithic Artifacts... . . . . . . . . . . . . . 45

Wood Artifacts .................. . . 61

Hide Artifacts . . . . . . . . . . . . . . . . . 62

Bone Artifacts . . . . . . . . . . . . . . . . 65

Fiber Artifacts .................. . 68

ANALYSIS OF PLANT REMAINS . . . . . . . . . . . . . 77

ANALYSIS OF ANIMAL REMAINS . . . . . . . . . . . . . 79

SUMMARY AND CONCLUSIONS . . . . . . . . . . . . . . . 89

REFERENCES CITED . . . . . . . . . . . . . . . . . 94 


\section{LIST OF FIGURES}

1. View of Baker Cave Looking West . . . . . . . . . . . . . 2

2. Biotic Provinces in the Study Area (as defined by Blair) and Pertinent Geographic Features . . . . . . . . . . . 4

3. Location of Selected Sites Within the Lower Pecos-Rio Grande Drainage and the Devil's River-Dolan Creek Study Area . . . . . 7

4. Plan Map of Baker Cave and Areas Tested by Word and Greer . . . . . 10

5. Calculation of Surface Area of Baker Cave . . . . . . . . . . 11

6. Profile of East Wa11, Word's Excavations at Baker Cave . . . . 13

7. Plan Map of 1976 Excavations in Relation to Prior Excavations, Baker Cave ................. 19

8. Grid and Surface, 1976 Excavations, Baker Cave . . . . . . . 20

9. North Profile of Hearth in Golondrina Zone, Operation 2, Zones 17-23, Leve1 7, Baker Cave, 1976 Excavations . . . . . . . 23

10. Profile of North Wa17, Operation 2, Baker Cave, 1976 Excavations . . 25

11. Grid and Surface, Operation 3, Baker Cave . . . . . . . . 27

12. Excavated Areas of Zone 2, Operation 3, Baker Cave . . . . . . 29

13. Excavated Areas of Zone 3, Operation 3, Baker Cave ........ 30

14. Excavated Areas of Zone 4, Operation 3, Baker Cave ....... 31

15. Excavated Areas of Zone 5, Operation 3, Baker Cave . . . . . . 32

16. Excavated Areas of Zone 6, Operation 3, Baker Cave ...... 34

17. Excavated Areas of Zone 7, Operation 3, Baker Cave ...... 35

18. Excavated Areas of Zone 8, Operation 3, Baker Cave ....... 36

19. Profile of West Wa11, Operation 3, Baker Cave, 1976 Excavations . . 38

20. Reconstructed Cross Section of Rows 8, 9, and 10, Operation 3, Baker Cave ................ . . 39

21. Work in Progress at Baker Cave, 1976 . . . . . . . . . 44

22. Projectile Points ................... . 46

23. Preforms, Bifaces, and Fragments ............ 51 
24. Clear Fork Tool and Scrapers ................. 55

25. Wood Artifacts .................... 63

26. Deer Skin Pouch or Garment ................. 64

27. Bone, Hide, and Fiber Artifacts .............. 67

28. Fiber Artifacts .................... 69

29. Plaited Basketry ..................... 71

\section{LIST OF TABLES}

1. Calculation of Area and Volume Sampled Within Baker Cave

by James H. Word and John W. Greer . . . . . . . . . . 15

2. Frequency and Distribution of Artifacts, Operation 2, Baker Cave . . 26

3. Frequency and Distribution of Artifacts, Operation 3, Baker Cave . . . 37

4. Calculation of 1976 Sample, Baker Cave . . . . . . . . . 42

5. Area and Volume of Baker Cave Sample to Date . . . . . . . . 43

6. Identification of Plant Remains from the Golondrina Complex Hearth Fill .................. 78

7. Identification of Plant Remains from Operation 2, Exclusive of the Golondrina Complex Hearth Fill . . . . . . . . 80

8. Identification of Faunal Remains from the Golondrina Complex Hearth Fill ................... 82

9. Identification of Faunal Remains from Culturally Sterile Basal Zone ................... . . . 84

10. Identification of Faunal Remains from Operation 2 (Exclusive of Golondrina Complex Hearth Fi11 and Basal Zone) and Operation 3.... 
FOREWORD

In this volume, Mary Frances Chadderdon has compiled and analyzed the data resulting from the 1976 excavations at the site of Baker Cave, Val Verde County, Texas. I have published some earlier summaries of these investigations through the Center for Archaeological Research (1977) and in papers in Archaeology magazine (1979) and the Bulletin of the Texas Archeological Society (1983). However, it is with the publication here of Chadderdon's research that we present many of the important details on which a number of conclusions have been based.

A second volume of papers stemming from the work of the 1976 Baker Cave project has been assembled and will soon go to press. These include detailed studies of the archaeological fauna, the paleobotanical remains, pollen, basketry technology, and a report on the excavation of an open campsite on the Baker Ranch.

Thomas R. Hester October 1983 


\section{ABSTRACT}

Excavations, in summer 1976, have provided new data on the ancient human occupations at Baker Cave, Val Verde County, Texas. One objective of the research program was to obtain further information on habitation at the site during Late Paleo-Indian times. Radiocarbon dates of 7000 B.C. can be linked to this period and are attributed to the Golondrina complex. This cultural pattern is represented by a deposit containing chipped stone artifacts and other cultural materials. The most important discovery was a cooking pit that yielded an abundance of faunal and floral remains. Interpretation of the paleoenvironmental data suggests a climatic regime somewhat more moist than that of today.

Overlying the Golondrina complex materials were strata ranging in age from 6000-3000 B.C. Chipped stone projectile points included triangular and stemmed forms distinctive of the early phases of the lower Pecos River Archaic. Paleoenvironmental data indicate a drying of the climate and the appearance of typical desert plants of the region. These deposits were capped by an occupation zone with Pandale points, diagnostic of the Early Archaic in the region.

A second objective of the 1976 investigations involved horizontal stripping of an area with stratified Middle Archaic to Late Prehistoric occupations. These excavations provided data on the spatial distribution of activity areas and on the procurement and processing of plants used for raw materials and for food. 


\section{ACKNOWLEDGMENTS}

The planning and execution of the 1976 excavations at Baker Cave were the work of Thomas R. Hester and Robert F. Heizer, Co-Directors of the project. The extraordinary success in meeting the objectives of this brief season's work is due in large measure to their expertly conceived research design and to their supervision of a crew composed of students, amateurs, and volunteers. Their field staff of graduate students consisted of Thomas C. Kelly, Harvey P. Smith, Jr., Janet Stock, Fred Valdez, Jr., Margarita Vazquez Dusek, and the author, some of whom did double duty as cooks and bottle washers. Joe and Wanda Kaufman and Anna Maria Ferraro, also students, came for several days to lend a hand. Jim and Dot Word visited from Floydada on two occasions and pitched in with enthusiastic hard labor. Bob Burnett of the Texas Parks and Wildlife Department assisted with surveying for the site grid layout.

The EARTHWATCH participants endured without complaint the extremes of drenching rainstorms and powdery limestone dust clouds, and deserve special praise. They were Susan Boyle, Audrey Brainard, George, Gypsy, and Kate Graves, Helen Gumpert, Helen Leven, Robert Mintz, Charles Nuckol1s, Marcia Romberg, Frank Spingola, Karen Wende11, and Jerry Wilbur. Brian Rosborough, president of EARTHWATCH, stopped by to greet us and to bring Fortune magazine writer Marityn Wellemeyer and photographer Michael Mauney, and stayed on many days to work. To all of them we are most grateful.

The preparation of this report has been greatly facilitated by Dr. Hester's distribution of the faunal and floral remains to specialists throughout the country, and by the flotation recovery of some of these remains done by his students at the University of California, Berkeley, when he was Visiting Associate Professor there in 1976. Summaries by him of the season's work have already appeared in three publications and a fourth is in process (Hester 1978, 1979, 1980, 1981). His suggestions and advice as my Thesis Director, as we11, have made his assistance invaluable. I am grateful, also, to the other two members of my Thes is Committee, Dr. R. E. W. Adams and Dr. Joel D. Gunn, for their guidance and constructive comments.

We are most appreciative of the time and effort expended by Harold $G$. Wooldridge, Melissa Winans, and Kenneth J. Lord, all of The University of Texas at Austin; Thomas Van Devender, Arizona Natural Heritage Program, Tucson; Amadeo M. Rea, Museum of Natural History, San Diego; and Michael L. Smith, University of Michigan, Ann Arbor, all of whom assisted in the identification of animal remains. We thank Ed Luther, Department of Paleontology, University of California, Berkeley, for his preliminary pollen scan; Phil Dering, Texas A\&M University, for identification of plant remains; and Liz Porter, also of Texas A\&M University, for the identification of wood species. The project is grateful to James M. Adovasio and R. L. Andrews, University of Pittsburgh, for their analys is of basketry samples. A publication now in preparation will include their reports. Thanks are also expressed to Harry J. Shafer, Texas A\&M University, who advised on the identification of some plant remains, and to Ernest L. Lundelius, The University of Texas at Austin, for his assistance in the identification of some animal remains. We appreciate, too, the expert assistance of Kathy Roemer and Augustine Frkuska in the final rendering of illustrations. 


\section{SPECIAL ACKNOWLEDGMENT}

The Baker Cave project extends its deepest gratitude to the Jim Baker family, on whose property the site is located. The Baker family recognized long ago the archaeological importance of the rockshelter and has resolutely protected it from looters and relic collectors. This perception of the vulnerability of our cultural resources is rare, and we are greatly in debt to the Bakers for preserving the site and for giving us permission to investigate it. The project members also extend their gratitude to Mary Baker Hughey, our host at the ranch during 1976. Her help and cooperation were vital to the success of the project. 


\section{INTRODUCTION}

In July 1976, a team directed by Thomas R. Hester, Professor of Anthropology and Director, Center for Archaeological Research, The University at Texas at San Antonio (CAR-UTSA), and the late Robert F. Heizer, then Professor of Anthropology and Coordinator, Archaeological Research Facility, University of California, Berkeley, undertook an 18-day investigation at Baker Cave (41 VV 213), a rockshelter in Val Verde County, Texas, on the property of Mrs. Mary Baker Hughey. Funding was secured through the Center for Field Research, an agency of EARTHWATCH, Belmont, MA, and from the Texas Archaeological Foundation. Logistical support was provided by the Center for Archaeological Research, UTSA, and the crew consisted of six staff members from the CAR and 13 EARTHWATCH participants.

The site is located in a remote section of the Baker ranch, about 45 minutes from the ranch house over a modestly developed ranch road. Because of the total lack of facilities at the site, Mrs. Hughey graciously allowed us to set up a tent camp not far from her ranch headquarters, where water and electricity were available. Most of our tents proved unequal to the downpour which intermittently assaulted us during the first five days of the season, and we were invited to move into a vacant barn on the property, which had formerly served to house livestock. A certain amount of shoveling and erecting of partitions followed, and Baker Barn continued to function as dormitory, mess hall, and laboratory for the remainder of our stay.

Even during periods of no precipitation, the extraordinarily fine soil (graphically described by local ranchers as "sugar sand") encountered in the soaked upland plateau, prevented our reaching the site for several days. On only a very few days of the season were we able to make the round trip without the use of a winch by which one of the three four-wheel drive vehicles hauled the Chevrolet Suburban out of one slippery bog after another. On one occasion, the big van had to extricate a jeep mired in mud to its fender tops and, on another, winched itself out with the aid of muscle power aft and a sturdy mesquite bush forward. At one time, Tom Kelly and four others spent the night in the rockshelter to avoid the time-consuming round trip.

For the first five days, however, even efforts such as these failed and forced our return, so that, when the skies permitted, forays in the vicinity of the camp were undertaken on foot. There was no lack of evidence of prehistoric occupation. Artifacts were collected and recorded from the vicinity of the barn (4l VV 536), and an occupation site was located only a short walk away. The site (41 VV 537), near the power lines of the Rural Electrification Administration, was given the field designation of the REA site and was investigated by controlled surface collection as well as by test excavation. Two sma11 rockshelters (41 VV 538), exposed in a bluff within sight of the REA locality, were examined and recorded. An extensive burned rock midden was located on an alluvial terrace of the Devil's River, between the REA site and the small shelters, and was recorded as 41 VV 539. These operations are reported separately (Stock 1977).

A July climate at last prevailed, however, and, through the ingenuity, determination, and unfailing good humor of the group, we put in 10 days of extremely productive work in the rockshelter itself (Fig. 1). 


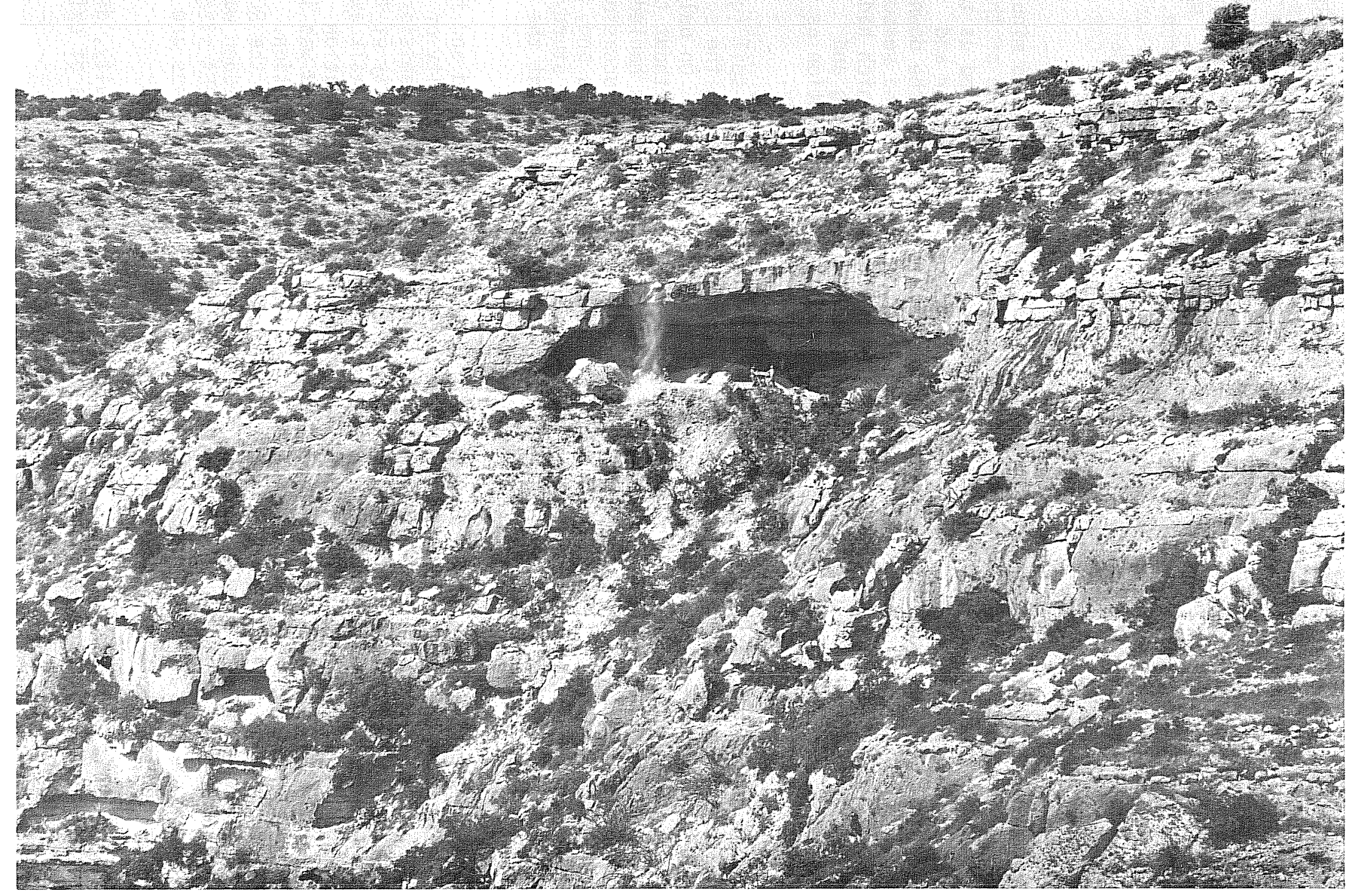

Figure 1. View of Baker Cave Looking west. Column of dust is from screening activity (photograph by George K. Graves III). 


\section{DISCUSSION OF THE REGION}

\section{Climate and Topography}

In general, the climate of the lower Pecos-Rio Grande area is described as semiarid, with an average annual rainfall of 18 inches, most of which occurs as showers in the summer months or heavy downpours during thunderstorms. Meteorological data from Del Rio, Texas, records temperature extremes of $11^{\circ} \mathrm{F}$ in February and $111^{\circ} \mathrm{F}$ in July, with a mean average temperature range from $51.6^{\circ} \mathrm{F}$ in January to $85.3^{\circ} \mathrm{F}$ in August. Winds average 10.6 miles per hour (Graham and Davis 1958:3).

The highly varied topography of Texas and Mexico, however, results in considerable differences in temperature and moisture content within very closely spaced areas. There is a shift from mesic to xeric conditions as moisture is carried from east to west from its principal source, the Gulf of Mexico. Air moving westward over the coastal plain and encountering the Balcones Escarpment, then the Edwards and Stockton Plateaus broken by the canyons of the Devil's and Pecos Rivers, is methodically "sapped" of moisture as atmospheric pressure decreases with rises in topography (Carr 1967:2). Within and between these river canyons themselves, moisture content varies subtly with elevation and distance from the Gulf of Mexico. The "influx of dry Mexican air and a change in the direction of the prevailing wind to more southerly - not directly from the Gulf of Mexico" is evident in the decreased rainfall of the Stockton Plateau, the Pecos Valley, and southern New Mexico (Carr 1967:24). These variations in temperature, rainfa11, and humidity are manifested in concomitant variations in vegetation and animal life. L. R. Dice (1943), in defining "biotic provinces" for North America, recognized this disparity when he established three such provinces for south and southwest Texas and Mexico: the Chihuahuan, the Balconian, and the Tamaulipan. These have been further refined in a regional study by W. F. BTair (1950:93-116; Fig. 2).

The Devil's River, which drains the canyon in which Baker Cave is located, flows southward from the far southwestern portion of the Edwards Plateau, crossing the boundary of the Balconian Biotic Province into the Tamaulipan. Thirty air miles west, the Pecos River forms the eastern boundary of the Chihuahuan Biotic Province. Lying as it does at a point of convergence of the three provinces, the Devil's River has long been recognized as an ecotone, or transitional area, between mesic or moist lands to the east and desert to the west (Dering 1977). Productivity and diversity are naturally increased by the "edge effect" produced by ecotones, and prehistoric populations appear to have concentrated in these ecotones (Rea 1979:12). In these zones, advantages of both sun and moisture are utilized, and extremes of both may be ameliorated.

The Devil's River is spring-fed throughout its course, and is heavily augmented where the waters of Dolan Springs and others join it, some 20 miles south of the Baker homestead. Only in the drought of the early 1950s has the river gone dry above these springs (Smith 1975:1). The other streams and tributaries in the drainage, such as Dolan Creek, Dry Devil's, and Phillips Creek (below Baker (ave) are intermittent, flowing only after heavy rains. The barren, overgrazed countryside is particularly susceptible to flash flooding and sudden, extreme rises. 


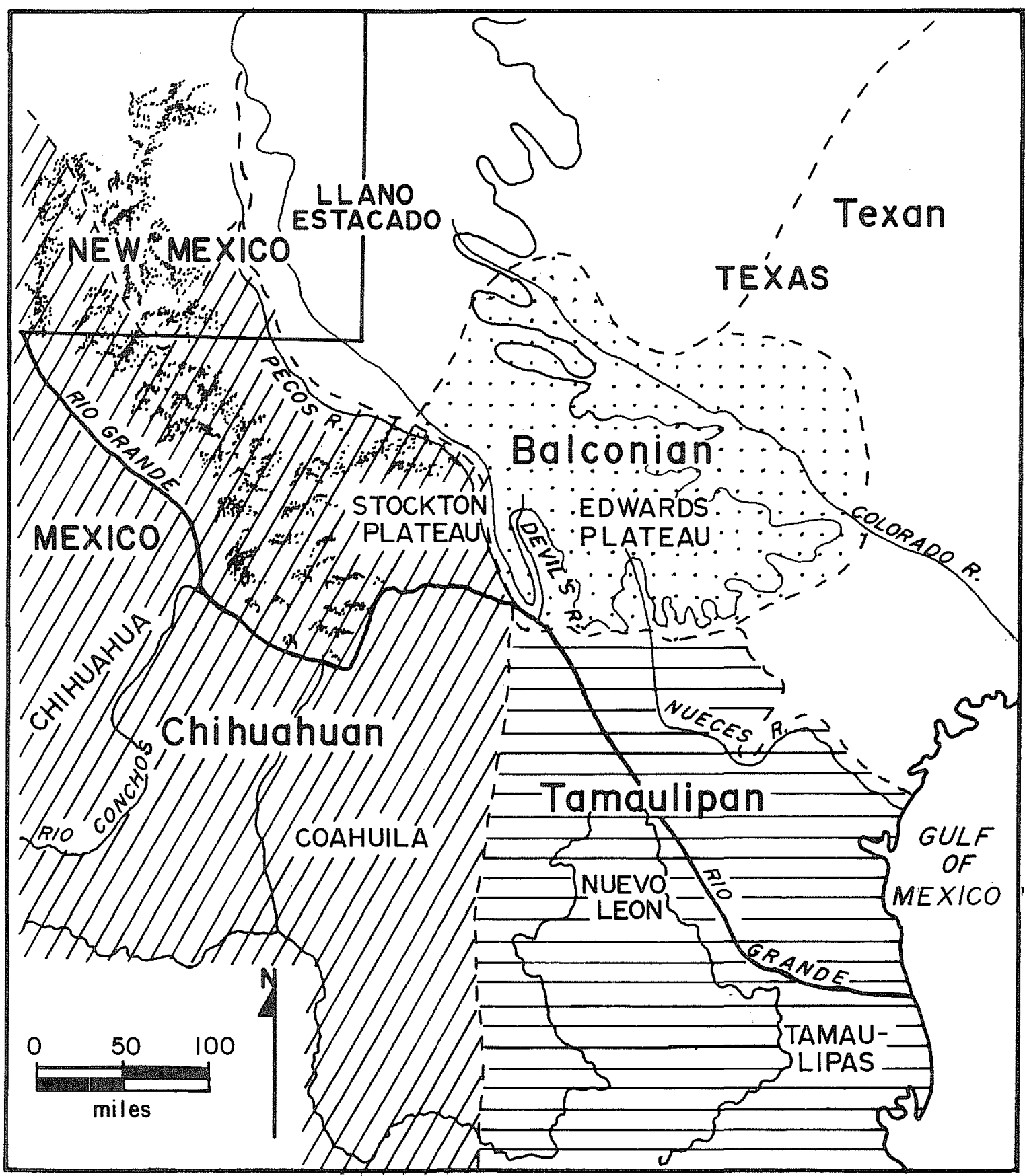

Figure 2. Biotic Provinces in the Study Area (as defined by Blair) and Pertinent Geographic Features. Adapted from a map by Vaughn M. Bryant, Jr. 
Vegetation

In a survey of the vegetational resources of the Devil's River, conducted by the Division of Natural Resources and Environment, The University of Texas at Austin, Smith and Butterwick (1975:36) describe the area as:

. . at the convergence of three major vegetational zones: the mesquite-chaparral of the South Texas Plains, the oak-cedar of the Edwards Plateau to the east, and the sotol-lechuguilla of the Trans-Pecos to the west . . . containing components of al1 three zones.

In this survey, noted as characteristic of the mesquite-chaparral vegetation, were thorny shrubs such as guaji110, mescat acacia, spiny hackberry, lotebush, brasil, and mesquite, as well as Mexican persimmon. Spanish oak, scrub live oak, shin oak, and Mexican juniper were described as typical of the oak-cedar association; cacti, catclaw mimosa, ocotillo, cenizo, sotol, and lechuguilla were defined as representative of the sotol-lechuguilla vegetation. All these zonal diagnostic varieties were found to be present in the lower Devil's River area. In addition, common on slopes and flats were agarita, Mexican buckeye, Texas mountain laurel, huisache, coyotillo, Spanish bayonet, prickly pear, tasajillo, and evergreen sumac. Ground cover was described as typical of a semidesert grassland, with Wright's three-awn grass, curly mesquite, slim tridens, blue three-awn, fall witchgrass, and six-weeks grama occurring most frequently. The study also reports that stream beds and scattered springs support mosses, fern, watercress, whorled pennywort, monkey flower, sycamore, desert willow, pecan, 1ittleleaf walnut, and Texas sugarberry. Various herbs and vines were found in profusion along springs and seeps in the lower elevations. One small stand of about 75 Mexican pinyon trees was observed 30 miles north of Del Rio. Once prevalent in Val Verde County (Bryant and Larsen 1968:64), the Mexican pinyons persist at low altitudes on the Edwards Plateau, but this single population near Devil's River showed root damage from erosion and bark girdling by porcupines, and contained only one young seedling. The Spanish oak, a zonal diagnostic of the Edwards Plateau, was observed in onty a few canyons leading into the Devil's River (Smith and Butterwick 1975:36-57).

David Flyr (1966:33-60), reporting on the vegetation of Val Verde County for the Amistad Reservoir project, found it to be unexpectedly diverse and suggested that this might be due to the high relief created by canyon dissection and the resultant variety of habitats, differing in availability of moisture. He observed that there is a general rise in elevation from southeast to northwest, and there is a "gradual diminution of the typical Edwards Plateau vegetation" (Flyr 1966:34). He notes that near the Devil's River the first specimens of ocotillo are seen and states that "this plant is definitely one of the distinct indications of the beginning of a true desert flora $1 \mathrm{ike}$ that of Trans-Pecos Texas" (Flyr 1966:37). The eastern boundary of lechuguilla appears to him to 7 ie near the Devil's River, and species of yucca, sacahuiste, and sotol begin to be prominent west of the Devil's River but east of the Pecos River.

Vegetation in the upland flats also expresses an east-west transition. South Texas species predominate here, such as mesquite, spiny hackberry, lotebush, Berlandier wolfberry, tasajillo, and shrubby blue sage. Creosote bush and 
tarbush, common in desert flatlands, are seen for the first time west of the Devil's River (Flyr 1966:38). Sotol, lechugilla, prickly pear, catclaw, Spanish bayonet, and mesquite were prevalent in the upland flats of the Baker Cave locality.

Fauna

Fifty-four species of mammals inhabit Val Verde County today (Word and Douglas 1970:143), including deer, bobcat, mountain lion, fox, badger, beaver, coyote, opossum, peccary (javelina), raccoon, porcupine, skunk, armadillo, mice, gophers, squirrels and other rodents, and several species of rabbit. Bison, bear, and pronghorn, remembered by grandparents of present residents (Word and Douglas 1970:3), are not found in the area today. Muskrat, represented by one lower jaw, was identified in the remains from Coontail Spin rockshelter and is now found in southeast Texas and in the western Big Bend region (Raun and Eck 1967:140). It is not thought to be present in the Devil's River area today, but other aquatic rodents, such as nutria and beaver, are known to occur at times along the lower Devil's River and near its confluence with Dolan Creek (Scudday and Hanselka 1975:74).

In the Devil's River-Dolan Creek area (Fig. 3), the mammalian fauna are mostly Chihuahuan, with some fairly common eastern species, such as the armadillo and opossum, seen along the Devil's River but seldom found west of the Pecos (Scudday and Hanselka 1975:58-75). The coyote and other large carnivores are rare in the area today, due to concentrated predator control by local sheep and goat ranchers, and the Botta pocket gopher is the only recorded gopher for the region. With only a few exceptions, however, all the mammals of Val Verde County are represented in the Devil's River drainage.

Amphibians include eight species of frogs and toads, one of which, the Gulf Coast toad, is not seen west of the Devil's River.

The reptilian fauna are exceptionally diverse, owing to the convergence of biotic provinces and to the variety of aquatic habitats which range from deep holes and shallow rapids to sandy, rocky creek beds. Turtles are common, with six varieties present, but the snake and lizard fauna illustrate best the transitional nature of the area. Seventeen species of lizard and 32 species of snakes are present today, eight of which are eastern forms present in their most southwestern distribution here or nearby. They are the Texas spring 1izard, ground skink, six-lined racerunner, alligator lizard, blue racer, rough green snake, flatheaded snake, and the coral snake. Four western forms, the graybanded king snake, the Trans-Pecos ratsnake, Baird's ratsnake, and the canyon lizard, reach their easternmost distribution here.

Twenty-nine species of fish have been identified in the Devil's River-Dolan Creek region today, including gar, catfish, bass, sunfish, drum, and perch. Habitat diversity and the kind of fish that can reach an area account for the variety, and they are divided into the categories of river fauna and a shallow creek and springs fauna. Variations in rainfall and spring seepage affect their appearance in the intermittent streams above Dolan Springs, but "shallow and semi-isolated springs have allowed the development of some species, particularly 


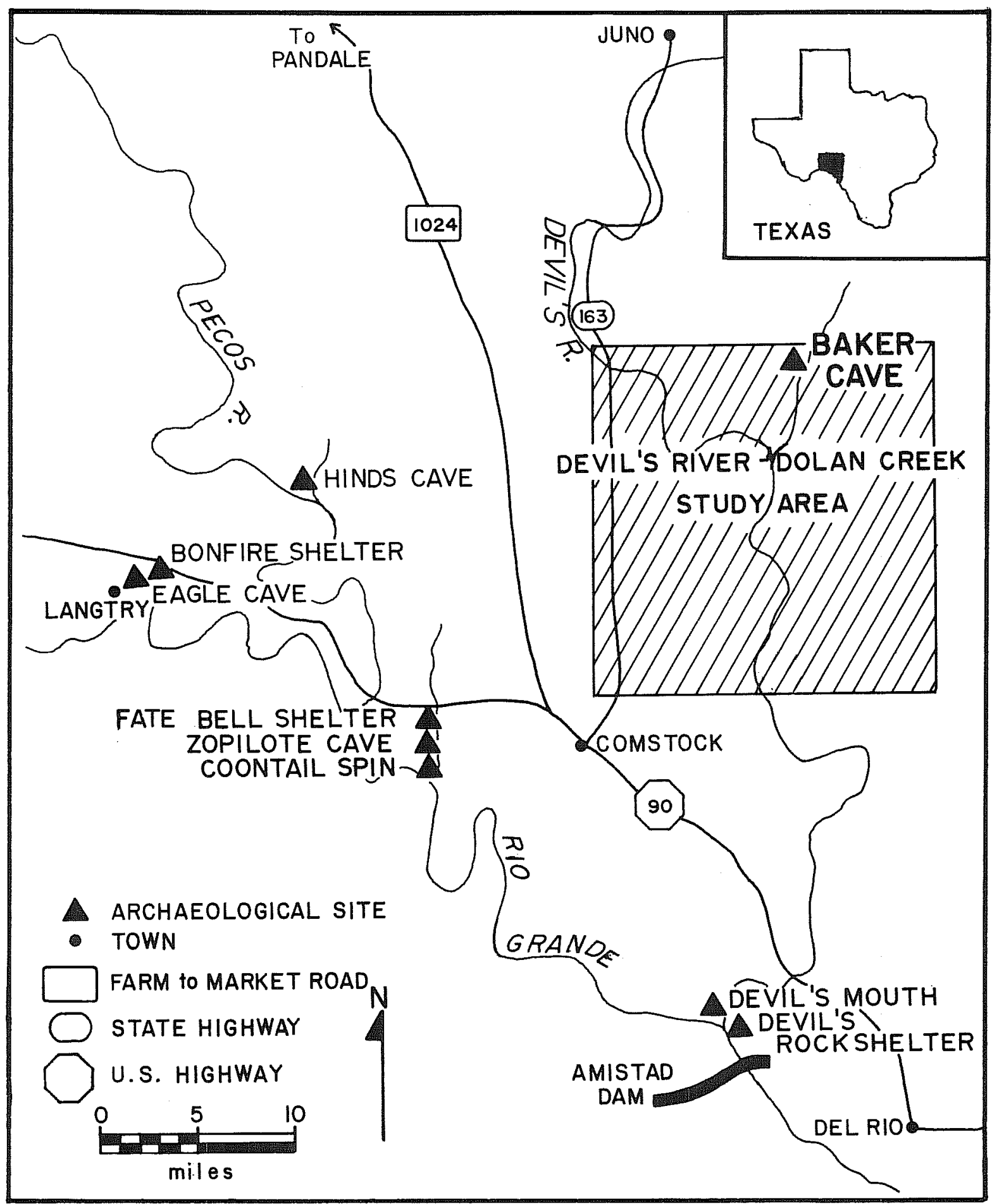

Figure 3. Location of Selected Sites Within the Lower Pecos-Rio Grande Drainage and the Devil's River-Dolan Creek Study Area. Adapted from Story and Bryant (1966). 
. . Gambusia, that probably could not exist if larger predaceous fish could get to them" (Scudday and Hanse1ka 1975:65).

Birds of the Devil's River-Dolan Creek area number 52 species, including the golden eagle, wild turkey, quail, bobwhite, vulture, doves, roadrunner, owls, hawks, heron, ducks, and a large variety of small birds. The avifauna of dry hills and slopes is primarily Chihuahuan, and the greatest diversity is seen along the stream beds in dense stands of trees and brush.

\section{Previous Archaeological Research}

As early as the 1930s archaeological work in the lower Pecos region was sponsored by The University of Texas (Pearce and Jackson 1933) and by the Witte Museum, San Antonio (Martin 1933; Davenport 1938; Schuetz 1956, 1961, 1963). Their primary interest at that time being the recovery of suitable museum specimens, these archaeologists gave little attention to systematic control and reporting of their work. Herbert C. Taylor (1949) attempted to construct a cultural sequence for the area, and a system of classification was proposed by Suhm, Krieger, and Jelks (1954).

Proposed construction of the Amistad International Dam and Reservoir on the Rio Grande, 12 miles upstream from the town of Del Rio, Texas, instigated a survey of the resources of the region (Graham and Davis 1958). This was followed by intensive investigation and excavation from 1958 until 1969 by the Texas Archeological Salvage Project, The University of Texas at Austin, prior to construction of the dam and creation of the reservoir, which is primarily contained within the deep canyons of the Rio Grande and the lower Pecos River. Over 300 sites were recorded within the flood pool on the United States side alone (Dibble and Lorrain 1968:10). Work at Centipede and Damp Caves was reported by Epstein (1963), and preliminary work at the Devil's Mouth site, an open occupational site, was reported by Johnson (1964). Preliminary work at three rockshelters, Coontail Spin, Mosquito Cave, and Zopilote Cave, as well as at the Doss site, a burned rock midden was reported by Nunley, Duffield, and Je1ks (1965). Additional excavation was recommended at several locations initially investigated in the 1930s, among which were Eagle Cave (Parsons 1965) and Fate Bell Shelter (Ross 1965). A third season at the Devil's Mouth site was described by Sorrow (1968). Bonfire Shelter, containing diagnostic projectile points among the remains of extinct mammals, was unique in the Amistad region in that it was the location of three separate bison kills resulting when the animals fell or were driven off the bluff overhead. Excavation of this shelter in 1963 and 1964 has been reported by Dibble (1965), Dibble and Lorrain (1968), and Dibble (1970).

Beginning in 1965, surveying and testing were done on a larger scale, and rockshelters examined during this time include Devil's Rockshelter (Prewitt 1966), Perpetual Care Shelter (Dibble and Prewitt 1967). Arenosa Shelter (Dibble 1967), the Perry Calk site and Techo Bajo Shelter (Collins 1969), Parida Cave (Alexander 1970), and Conejo Shelter (Alexander 1974). A study of the paleoecology of the region, based on seven sites within the reservoir area, was assembled by Story and Bryant (1966; Fig. 3). 
Hinds Cave, which, like Baker Cave, is one of many rockshelters not endangered by the reservoir (Fig. 3), was excavated in 1975 and 1976 by Harry J. Shafer and Vaughn M. Bryant, Jr., and has been reported with particular emphasis on the paleoecology of the region (Shafer and Bryant 1977; Wi11iams-Dean 1979; Dering 1979; Shafer 1981). Fiber artifacts from Hinds Cave have been analyzed by Andrews and Adovasio (1980).

\section{DESCRIPTION OF THE SITE}

Physical Characteristics

Baker Cave is located on a high bluff in Val Verde County, in the lower Pecos region of southwest Texas. It is at an elevation of 1800 feet $(558 \mathrm{~m}$ ) above mean sea level (msl) and overlooks Phillips Creek, a dry tributary of the Devil's River (Fig. 3). The remnant of a solution cavity in Cretaceous limestone of the Comanche Series, the cavity has been dissected by the steep canyon cut by river action and is now a semicircular opening in the canyon wall, with an arching overhang of bedded limestone, subject to periodic collapse. The opening, about $27 \mathrm{~m}$ long, faces northeast, and the shelter enjoys a steady breeze entering from the north, although the interior remains quite dry even during heavy rainfall.

The floor of the shelter is roughly crescentic in shape, but broader in the southern portion where wind erosion has widened the outside of the natural bend at the back of the curved cavity (Fig. 4). According to Word's (Word and Douglas 1970:4) measurements, maximum interior length of the shelter is about 120 feet $(37 \mathrm{~m})$, and maximum width is 56 feet $(15 \mathrm{~m})$. Based on these figures, the total surface area is calculated at approximately 4356.25 square feet $\left(451.5 \mathrm{~m}^{2}\right.$; Fig. 5). The present floor surface is of decomposed 1 imestone with a liberal mixture of sheep dung. It is littered with chunks of roof spall, ranging in size from pebbles to very large boulders. The fill of Baker Cave varies in depth from 2.5 to $3.5 \mathrm{~m}$ and consists of deposits of 1 imestone spall and dust, alternating with layers of plant parts and fiber of the native vegetation. It is dry to a depth of about $1.5 \mathrm{~m}$. At present the ceiling is about six meters above the surface of the mouth of the shelter, curving gradually downward to a height of less than one meter at the back. Accumulated deposits follow a slope of about $25^{\circ}$ from back to front (west to east). A talus slope of fallen rock and midden debris has formed at the mouth of the shelter, dropping off steeply to the floor of the canyon some $85 \mathrm{~m}$ below. The only practical present-day approach to the shelter is a descent from the upland plateau overhead, by means of nearby sma11, connecting ravines in the cliff face. There is no visible source of water other than the creek bed below.

\section{Prior Excavations at the Site}

The landowner families have steadfastly protected the site from relic collectors, and its deposits have not been significantly disturbed. This is not true of the majority of the shelters in the lower Pecos-Rio Grande drainage (Shafer and Bryant 1977:4). Most of these roofed cavities contain the debris of prehistoric occupation (Lehmer 1960), and the accumulation of weathered limestone has, in 


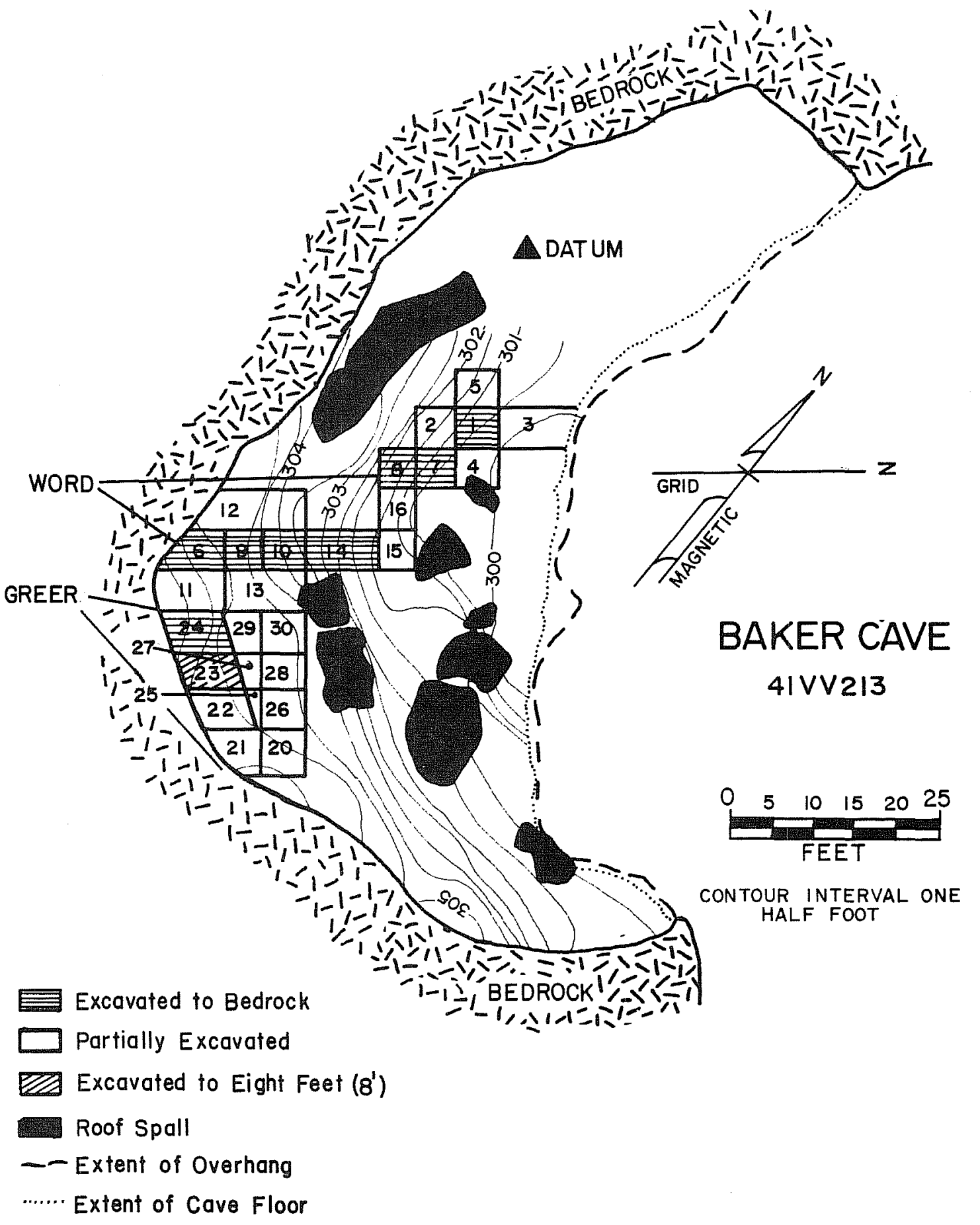

Figure 4. Plan Map of Baker Cave and Areas Tested by Word and Greer. Adapted from a map by James $H$. Word. 


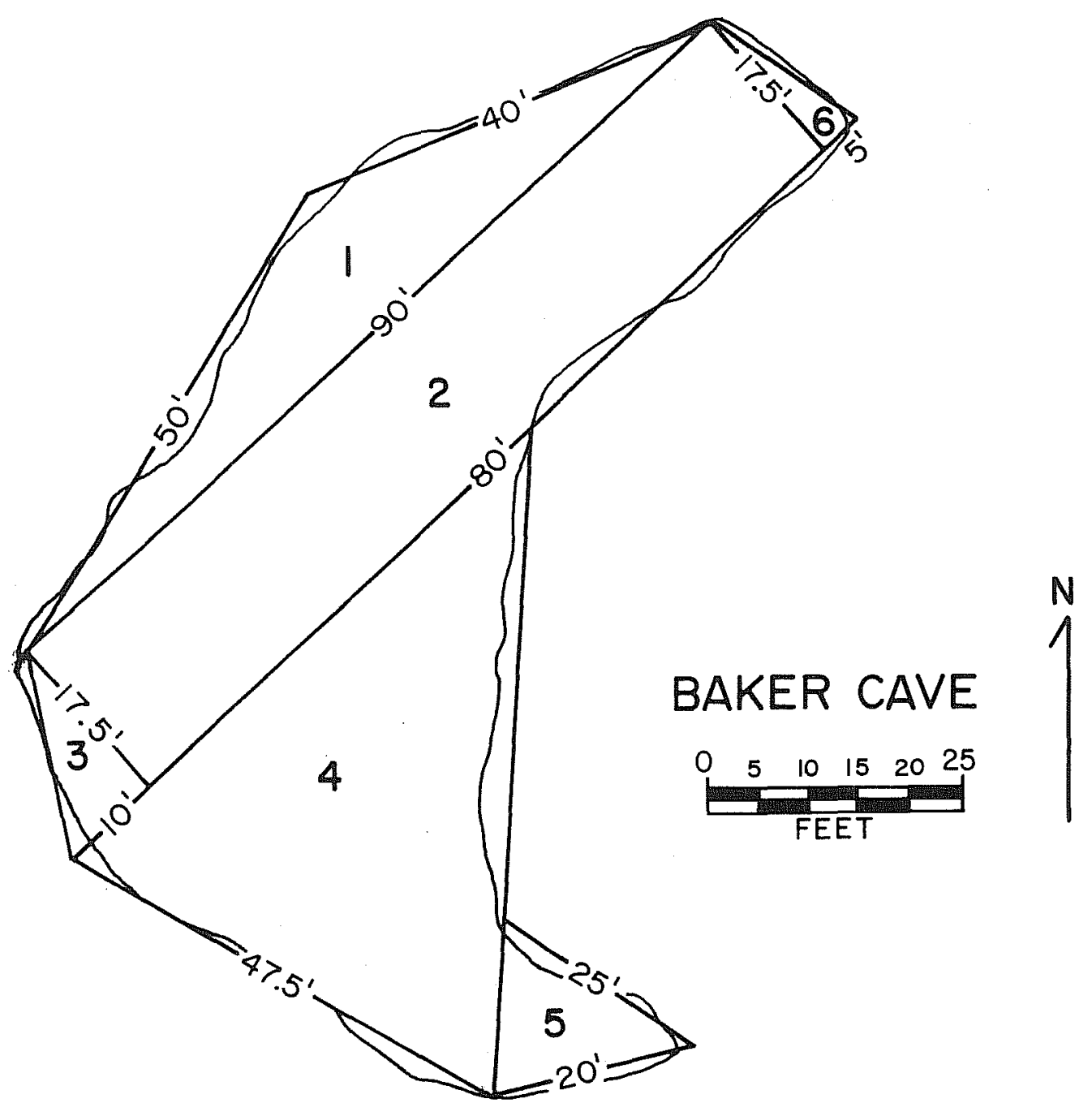

1. $40 \mathrm{ft} \times 50 \mathrm{ft}=\frac{2000}{2}=1000.00 \mathrm{ft}^{2}$

2. $17.5 \mathrm{ft} \times 90 \mathrm{ft}=1575.00 \mathrm{ft}^{2}$

3. $17.5 \mathrm{ft} \times 10 \mathrm{ft}=\frac{175}{2}=87.50 \mathrm{ft}^{2}$

4. $47.5 \mathrm{ft} \times 80 \mathrm{ft}=\frac{3800}{2}=1900.00 \mathrm{ft}^{2}$

5. $25 \mathrm{ft} \times 30 \mathrm{ft}=\frac{500}{2}=250.00 \mathrm{ft}^{2}$

6. $17.5 \mathrm{ft} \times 5 \mathrm{ft}-\frac{87.5}{2}=\frac{43.75 \mathrm{ft}^{2}}{4856.25 \mathrm{ft}^{2}} \times .093=451.63 \mathrm{~m}^{2}$

Figure 5. Calculation of Surface Area of Baker Cave. Adapted from a map by James $H$. Word. 
some cases, preserved articles of fiber, wood, bone, and hide which are perishable in open sites exposed to moisture and soil chemicals. These ancient artifacts have, understandably, long been of interest to both the merely curious and the wantoniy destructive.

In 1962, permission to excavate Baker Cave was given to James $H$. Word, a family friend of the Bakers, and an experienced avocational archaeologist, who carefully and methodically investigated a portion of the deposits over a period of four years. A11 references in this paper to his work are taken from the published account of his excavations (Word and Douglas 1970). Working from a grid of five-foot $(1.5 \mathrm{~m})$ squares, Word first excavated a test pit in the north central section, about 10 feet (three meters) west of the mouth of the shelter. He reached bedrock at a depth of about three meters and, to avoid wall collapse, then excavated each of the four adjacent squares to depths of about four feet $(1.2 \mathrm{~m})$. Two more $1.5 \mathrm{-m}$ squares to the west were excavated to bedrock, then two adjacent squares to the south were taken down to $1.2 \mathrm{~m}$. He was then at the approximate center of the shelter and proceeded to excavate to bedrock a 25 -foot $(7.3 \mathrm{~m})$ trench west to the back wa17. Trenches $1.5 \mathrm{~m}$ wide, on each side of the rear ma in trench, were taken down to a depth of about $1.2 \mathrm{~m}$, on the north a section 12.5 feet $(3.8 \mathrm{~m})$ long, and on the south, one of 18 feet (5.8 m; Fig. 4).

As a result of his excavations, Word established five vertical "zones, "representing major divisions of soil units based on color, content, and texture (Fig. 6). Strata of limestone dust were bel ieved to be sterile and were not numbered (Word and Douglas 1970:10). Evidence of human habitation in the form of cultural material or burned rock and fiber from fire pits was found in all zones. Of especial importance in the decision to examine further this particular site was his discovery in the lowest cultural stratum (Zone I) of six Late Paleo-Indian projectîle points of a type he classified as Plainview golondrina. One of these artifacts, on the basis of radiocarbon assays of two charcoal samples found in association with $i t$, has been assigned dates of $8910 \pm 140$ B.P. (6950 B.C.; Tx-128) and $9030 \pm 230$ B.P. (7080 B.C.; Tx-129). Projectile point types representing all of the seven prehistoric periods proposed by Story (Story and Bryant 1966:10-12) as a tentative chronology for the Amistad Reservoir area were recovered by Word, and a Baker Cave sequence of six periods was proposed by him (Word and Douglas 1970:98-101).

In 1968, John W. Greer, then a graduate student at The University of Texas at Austin, conducted a summer's work at the site, under the supervision of Dr. Dee Ann Story. References in this paper to Greer are taken from his manuscript and notes (Greer 1968a). Greer excavated portions of a roughly triangular block at the rear of the shelter, abutting the 5.8-m section removed by Word to the south of his main trench. Greer, too, operated from a grid of five-foot $(1.5 \mathrm{~m})$ squares, but was obliged to alter the grid toward the west, to conform to the curvature of the rear wall (Fig. 4). He excavated one unit measuring six feet $(1.85 \mathrm{~m})$ on each side to a depth of eight feet $(2.5 \mathrm{~m})$, another square of $1.85 \mathrm{~m}$ on a side to bedrock at 11 feet $(3.5 \mathrm{~m})$, and the remaining 205 square feet $\left(19.06 \mathrm{~m}^{2}\right)$ of the gridded area to an average depth of $1.5 \mathrm{~m}$, the depth of excavation gradually increasing from east to west. At this $1.5 \mathrm{~m}$ level, an increasing frequency of projectile points of the Pandale type, dated at about 2600 B.C.

IProjectile point typology in this paper follows that set forth by Suhm and Jelks (1962). 


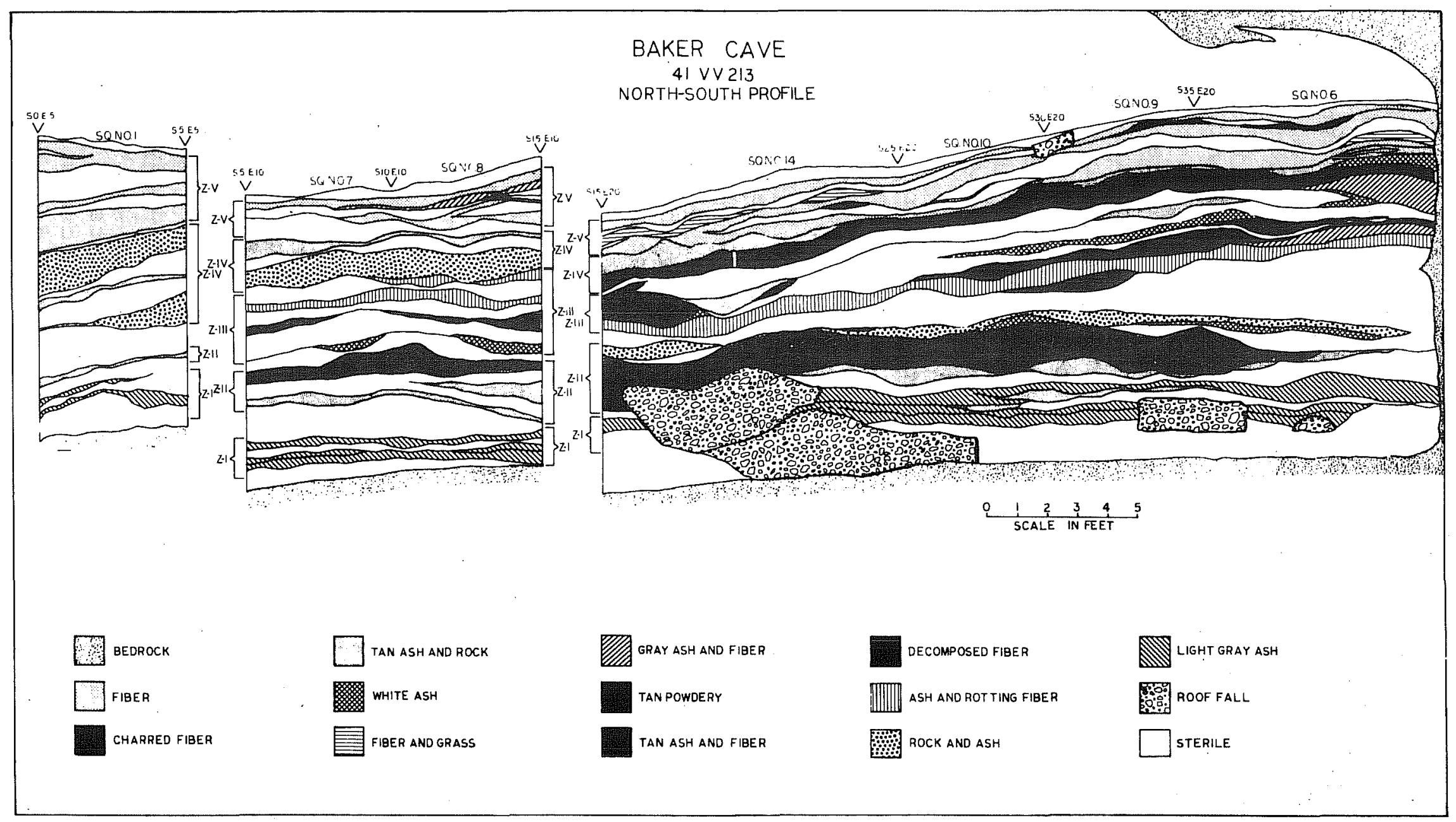

Figure 6. Profile of East Wall, Word's Excavations at Baker Cave. From Word and Douglas (1970, Fig. 5). Courtesy of Texas Memorial Museum. 
(Ross 1965:138), was noted as Greer terminated his excavations. This depth coincides approximately with the bottom of Word's Zone IV, and the vertical sequence of projectile point types found by Greer correlates well with that determined by Word. In the section taken to bedrock, the base of a projectile point classified by Greer as Plainview golondrina was found one foot $(0.3 \mathrm{~m})$ above the shelter floor.

\section{Extent of Sampling}

Since both Word and Greer surveyed and excavated in units of feet and inches, the area and volume of the shelter deposits have been computed in those units and converted to metric equivalents by means of the Universal English/SI (metric) Datalizer Slide Chart calculations: $1 \mathrm{ft}^{2} \times .093=1 \mathrm{~m}^{2} ; 1 \mathrm{ft}^{3} \times$ $.028+1 \mathrm{~m}^{3}$ (Fig. 5, Table 1). The average depth of the deposit is estimated at 10 feet (three meters), based on the measurements of both excavations. The fill in the northern section of the shelter is relatively level and well packed, and appears to have less depth than the deposits in the central and southern sections. This portion has not been tested, however, and its condition may be the result of its use as an access route by the various teams of excavators. The surface grade of about $25^{\circ}$ from back to front has not been taken into account, partly because the extended profile of Word's excavation indicates a corresponding slope (although of a lesser angle) of the bedrock floor, and partly because of the evident compaction of the fill resulting from continued use of the areas where it is possible to stand erect. The fill toward the center rear of the shelter has risen so high on the ceiling arch that it is unusable by any but small creatures and has suffered less compression. The figure used for depth is, admittedly, an arbitrary one, but it is a fair approximation. On this basis, an estimate of the extent of sampling by Word and Greer is presented in Table 1. For a calculation of total sampling of Baker Cave to date, see Table 5 .

\section{RESEARCH DESIGN}

\section{Background}

The Paleo-Indian period of Late Pleistocene occupation in south and southwest Texas is not well documented. Clovis points, dated at 9200 B.C., are widely accepted as the oldest projectile points in North America (Haynes 1964). They have been discovered in this region, but usually as isolated surface finds and not in clear association with extinct fauna or artifactual materials. The base of a Clovis point was found on the west bank of the Devil's River about 23 miles north of Comstock, Texas, adjacent to a midden circle site (Greer 1968b:184). The Folsom point, dated at about 8800 B.C. (Haynes 1964), has also been reported in scattered finds in south and southwest Texas and has been excavated in at least three subsurface depositional contexts. At 41 BX 52, an occupational site in northwest San Antonio, Folsom points, scrapers, and other stone tools representative of the Folsom complex were excavated in 1979 by the Archaeology Section of the Texas Department of Highways and Public Transportation (Hester 1980:134). A single Folsom point was excavated at the St. Mary's Hall site (41 BX 229) in San Antonio, but there was evidence of extensive erosion at the site in ancient times, and the specimen was not in situ. Near 
TABLE 1. CALCULATION OF AREA AND VOLUME SAMPLED WITHIN BAKER CAVE BY JAMES H. WORD AND JOHN W. GREER

\author{
SAMPLING OF AREA \\ Total Area $451.50 \mathrm{~m}^{2}$
}

$100.00 \%$

WORD

To $10 \mathrm{ft} \quad 206.00 \mathrm{ft}^{2}$

To $4 \mathrm{ft} \frac{317.50}{523.50 \mathrm{ft}^{2}}$
$\underline{x .093}=48.62 \mathrm{~m}^{2}$
$10.76 \%$

GREER

To $10 \mathrm{ft} \quad 42.00 \mathrm{ft}^{2}$

To $8 \mathrm{ft} \quad 36.00$

To $5 \mathrm{ft} \quad 205.00$

$$
\begin{aligned}
& 283.00 \mathrm{ft}^{2} \\
& \times .093=26.32 \mathrm{~m}^{2} \\
& \hline
\end{aligned}
$$

$74.94 \mathrm{~m}^{2}$

$5.80 \%$

$16.56 \%$

(Unsampled)

$\left(376.56 \mathrm{~m}^{2}\right)$

$(83.44 \%)$

SAMPLING OF VOLUME

Total Volume $1355.00 \mathrm{~m}^{3}$

$100.00 \%$

WORD

To $10 \mathrm{ft}$

$\left(206 \mathrm{ft}^{2}\right) \quad 2060.00 \mathrm{ft}^{3}$

To $4 \mathrm{ft}$

$\left(317.5 \mathrm{ft}^{2}\right) 1270.00$

$3333.00 \mathrm{ft}^{3}$

$\underline{x \quad .028}=93.32 \mathrm{~m}^{3}$

$6.88 \%$

GREER

To $10 \mathrm{ft}$

$\left(42 \mathrm{ft}^{2}\right) \quad 420.00 \mathrm{ft}^{3}$

To $8 \mathrm{ft}$

$\left(36 \mathrm{ft}^{2}\right) \quad 288.00$

To $5 \mathrm{ft}$

$\left(205 \mathrm{ft}^{2}\right) \quad 1025.00$

$1733.00 \mathrm{ft}^{3}$

$\times \quad .028=48.52 \mathrm{~m}^{3}$

$141.84 \mathrm{~m}^{3}$

$3.58 \%$

$10.46 \%$

(Unsampled)

$\left(1213.16 \mathrm{~m}^{3}\right)$

$(89.54 \%)$ 
Sabinal in Uvalde County, on the edge of the Edwards Plateau, excavations in 1947 at Kincaid Rockshelter exposed the remains of extinct bison in a deposit more than three meters in depth, and Folsom points were found nearby in the backdirt left by relic collectors (Sellards 1952). To the east, in Travis County, Levi Rockshelter yielded artifacts in apparent association with remains of extinct tapir and dire wolf, underlying.occupational remains dated at 8050 B.C. (Alexander 1963).

In the lower Pecos region, the earliest firm evidence of Paleo-Indian occupation comes from Bonfire Shelter, a bison-kill site in Val Verde County (41 VV 218), where a Folsom point was found in a stratified deposit of extinct bison remains dated at 8350 B.C. Plainview points from this site have been dated at 8200 B.C. (Dibble and Lorrain 1968; Dibble 1970). Mammoth (usually associated with the Clovis complex) was tentatively identified along with bison in Bone Bed 1, but this lowest deposit was not extensively tested. At $41 \mathrm{VV} 162 \mathrm{~A}$, a smal1 rockshelter near the Rio Grande, about two miles above the mouth of the Pecos River, radiocarbon dates older than those from Bonfire Shelter have been obtained on burned Pleistocene fauna, and unifacial stone tools may be associated with the deposit (Shafer 1981).

At this writing, the earliest dated occupation is in south Texas at the Berger Bluff site in Goliad County (41 GD 30A), where a radiocarbon date of 9600 B.C. has recently been obtained from an occupational zone (lacking Pleistocene fauna) at a depth of $7.8 \mathrm{~m}$ (Kenneth $M$. Brown, personal communication). It is clear that south and southwest Texas were occupied by man during the Late Pleistocene; it remains to discover the extent and character of that occupation.

From about 8000 B.C. to 6000 B.C., a diversity in projectile point types and cultural patterns is observed throughout North America. This period of intermittent warming as the ice sheets retreated relates to the end of the large Pleistocene mammals, and the diversity of point styles may indicate a trend toward the hunting of smaller game. It probably reflects, as well, an increased human population, spreading into ever more diverse environments and developing regional adaptations to the available resources. This Late PaleoIndian period is well represented in Texas by the projectile points typed as Plainview, Scottsblufo, Angostura, and others, but the cultural sequence of this 2000-year long period is not sufficiently understood. The recent identification of the Golondrina point as a separate type is a specific case.

The "golondrina" variant of the Plainview type was first recognized by LeRoy Johnson, Jr., (1964) as a result of work conducted at the Devil's Mouth site (41 VV 188). The Golondrina point is similar in size and lanceolate form to the Plainview point, but is differentiated by out-flaring basal corners and a deeper basal notch, giving it a somewhat "swallow-tail" appearance. Flaking on the Golondrina point is less precise and controlled than on the Plainview point, and basal thinning is customarily achieved by removal of one or more small flakes, rather than by the long, narrow flakes which are characteristic of the "classic" Plainview bases (Johnson 1964:49). Research by Johnson revealed that this "variant," usually grouped with Plainview specimens, had been reported from no less than 30 counties of central, southern, and western Texas, and was known to be present in northeastern Mexico (Johnson 1964:50). A radiocarbon date of 6830 B.C. was obtained on charcoal from the stratum in which two Plainview golondrina points were found during the third season's work at the Devil's Mouth site by Sorrow (1968:47). 
The gradual acceptance of the Golondrina points as representing a separate complex of somewhat later date than that of the Plainview points has been justified by a computer analysis of attributes done by Thomas C. Kel1y (1976), suggesting that the two types are, indeed, discrete.

Objectives

A primary objective set forth in the research design for this excavation was that of obtaining information regarding cultural resources and activities which would refine in some degree the current gross chronological sequence of Late Paleo-Indian groups in the region, with emphasis on the tentatively defined Golondrina complex. The "bench" resulting from Greer's work provided quick access to deposits laid down prior to 2600 B.C. and the opportunity to examine those deposits within the 1 imited time available. In addition, we wished to examine further the basal zone for evidence of an even earlier occupation.

The trenches created by Word's excavation had exposed stratigraphic profiles on two adjacent sides of a small block at the center rear of the shelter, revealing layers of fiber al ternating with deposits of limestone dust (Fig. 6). This presented an ideal situation in which to attempt a secondary objective, that of open-area excavation, or horizontal stripping away of these stratified deposits in an effort to expose an occupation surface. We hoped to be able to identify activity areas, learn the nature and purpose of the fiber deposits and, if, as Word (Word and Douglas 1970:10) believed, the 1imestone dust strata were sterile, discover if an occupational cycle could be determined. The size of the remnant block permitted a horizontal excavation of only $9 \mathrm{~m}^{2}$, but we were to be unobstructed by any balks or pit walls on three sides. A second experimental technique was proposed for recovery and handling of fiber deposits, in which segments within a one-meter square were to be cut free, lifited out intact, and transported without disturbance for later investigation in the laboratory. Previous attempts had been made by archaeologists to expose and examine fiber deposits in the shelters of this region. Collins (1969:46-50), while excavating Techo Bajo Shelter (41 VV 422), had exposed an area $3 \mathrm{~m} \times 4.5 \mathrm{~m}$ in order to study a thin fiber lens which overlay damp deposits. He reported that the lens appeared to represent a single, brief occupation by a sma11 group and that parts of it suggested intentional preparation. At Parida Cave (41 UV 187), Alexander (1970:17) attempted to excavate a $2.8 \mathrm{~m}^{2}$ unit by "peeling away thin lenses composed of vegetal detritus . . . following natural planes of separation," but the plan was abandoned after the removal of four such lenses when he encountered a damp, ashy deposit disturbed by rodents. Deposits were not deep at this site; a schematic profile indicates the depth of the operation described above as less than $0.3 \mathrm{~m}$ (Alexander 1970:16). Horizontal or openarea excavation has not generally been productive in this region. Many of the shelters in the lower Pecos area, such as the Perry Calk site, 41 VV 87 (Collins 1969); Fate Bell Shelter, 41 VV 74 (Graham and Davis 1958; Parsons 1965); Devil's Rockshelter, 41 VV 264 (Dibble and Prewitt 1967); and Eag7e Cave, 41 VV 167 (Graham and Davis 1958; Ross 1965) have been found to contain varying degrees of moisture below the uppermost strata. Parida Cave (41 VV 187) had a seep in the rear wall, rendering the surrounding midden quite damp (Alexander 1970:9). Intact recovery of perishable artifactual material from the older levels of these deposits was, perforce, limited. Word and Greer had described 
the Baker Cave deposits as dry to a depth of about $1.5 \mathrm{~m}$, and a significant number and variety of these perishable artifacts were recovered in good condition by them to that depth.

\section{METHODOLOGY FOR THE 1976 EXCAVATIONS}

A datum, representing an arbitrary elevation of $100 \mathrm{~m}$ above ms 1 , was established at a large nail driven into the rear wal1, corresponding to the vertical reference used by Greer. A grid of one meter squares was laid out over the areas to be examined, oriented to magnetic north instead of to the arbitrary north used by both Word and Greer (Fig. 7). Metal spikes one meter in length were used as corner stakes to provide greater support in the unstable matrix, and surface elevations were obtained at the southeast stake of each unit. Squares were numbered sequentially from south to north and from west to east, e.g., $\mathrm{N} 1 / \mathrm{El}, \mathrm{N} 2 / \mathrm{El}$ or $\mathrm{N1/E1}, \mathrm{N} 1 / \mathrm{E2}$. Some of the units were incomplete, sections of them having collapsed or been removed during the previous work. N2/El, because of its irregular and fragmentary conformation, was incorporated with its adjacent square into a one by two meter unit designated N2/E2.

The southernmost units, placed over Greer's bench where the deep excavation was planned, were designated Operation $2^{1}$ and included North Units 1 through 4. Those parts of the grid that would have been numbered N5, N6, and part of N7 had been removed by Word's trench. Operation 3, the section to be exposed horizontally, included North Units 7,8,9, and 10 (Fig. 8). The surface was mapped and artifacts collected. During excavation, artifacts were plotted in place where possible, and all loose material was screened through both 1/4-inch and 1/8-inch wire mesh. Fiber layers were removed as units, following natural contours, and were hand sorted for artifacts over the double screens. A sample of material caught by the 1/8-inch screen was preserved from each unit level. All work was done by hand, using trowel and brush.

\section{Operation 2}

Clearing of the surface level began at an average elevation of $93.6 \mathrm{~m}$ and correlation was established with Greer's Zone 12 at his maximum depth of $1.4 \mathrm{~m}$ in that area. Excavation was done by natural strata, following the slope of the fill from west to east, and incorporating (with some modification) Greer's numerical sequence as established in the deep excavation of his Unit 24 . Zone 12 was a discontinuous fiber layer containing cultural material including the burned base of a Pandale point, the base of a point classified by Word as Baker I, and a fragment of basketry. A round wooden stake, $2.3 \mathrm{~cm}$ in diameter, driven vertically into the matrix, was first observed at this level in N2/E2.

Zone 13, a thin deposit of brown dust and ash with scattered fiber, contained an unfinished Pandale and two triangular points. Zone 14, consisting mostly of spall and dust in the west, was a thick layer of fiber in the east, dropping off sharply with the slope. Cultural material was abundant in this zone.

\footnotetext{
1 The designation Operation 1 was given to artifacts collected during a preliminary visit to the site by Hester and Word.
} 


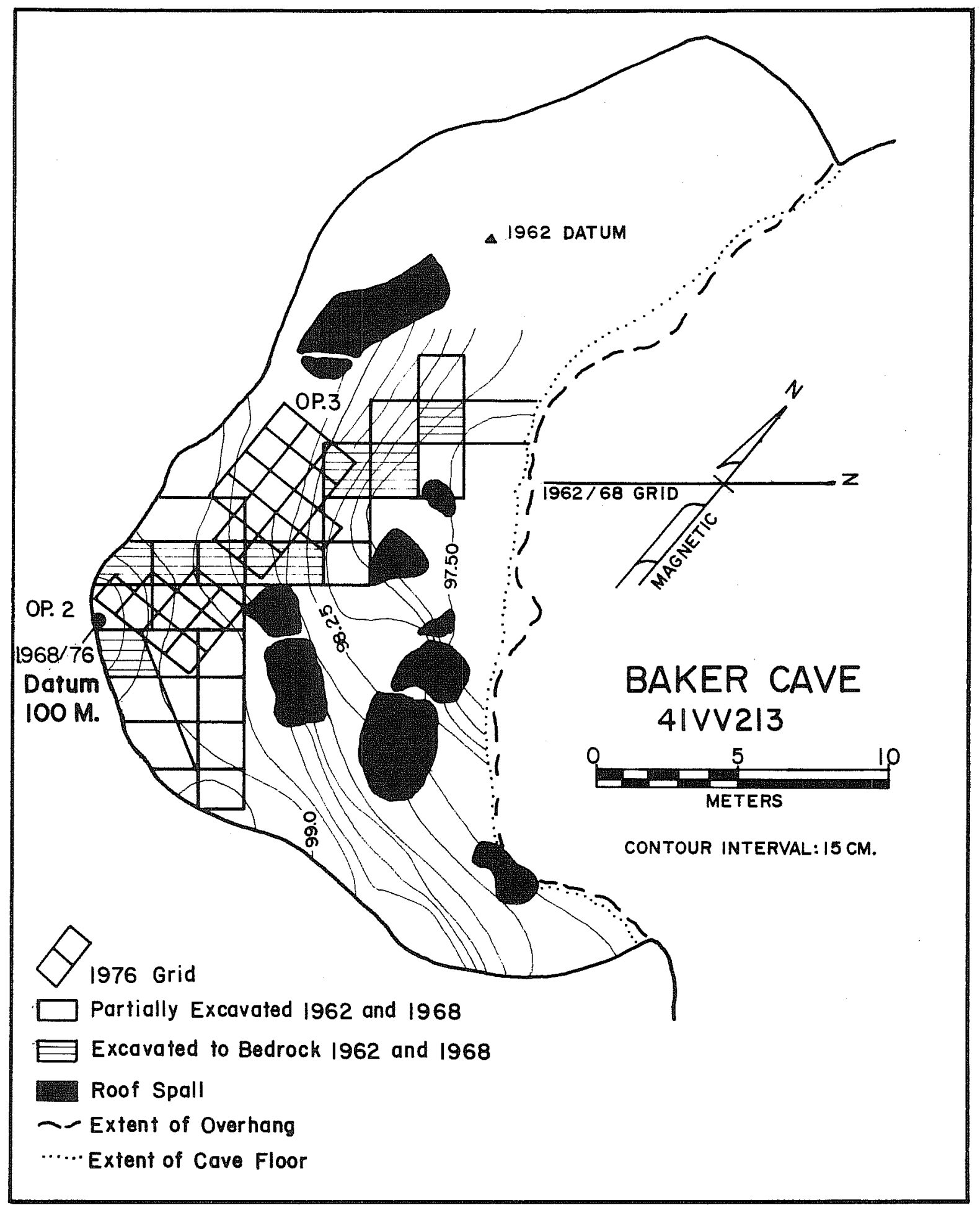

Figure 7. Plan Map of 1976 Excavations in Relation to Prior Excavations, Baker Cave. Adapted from a map by James H. Word. 


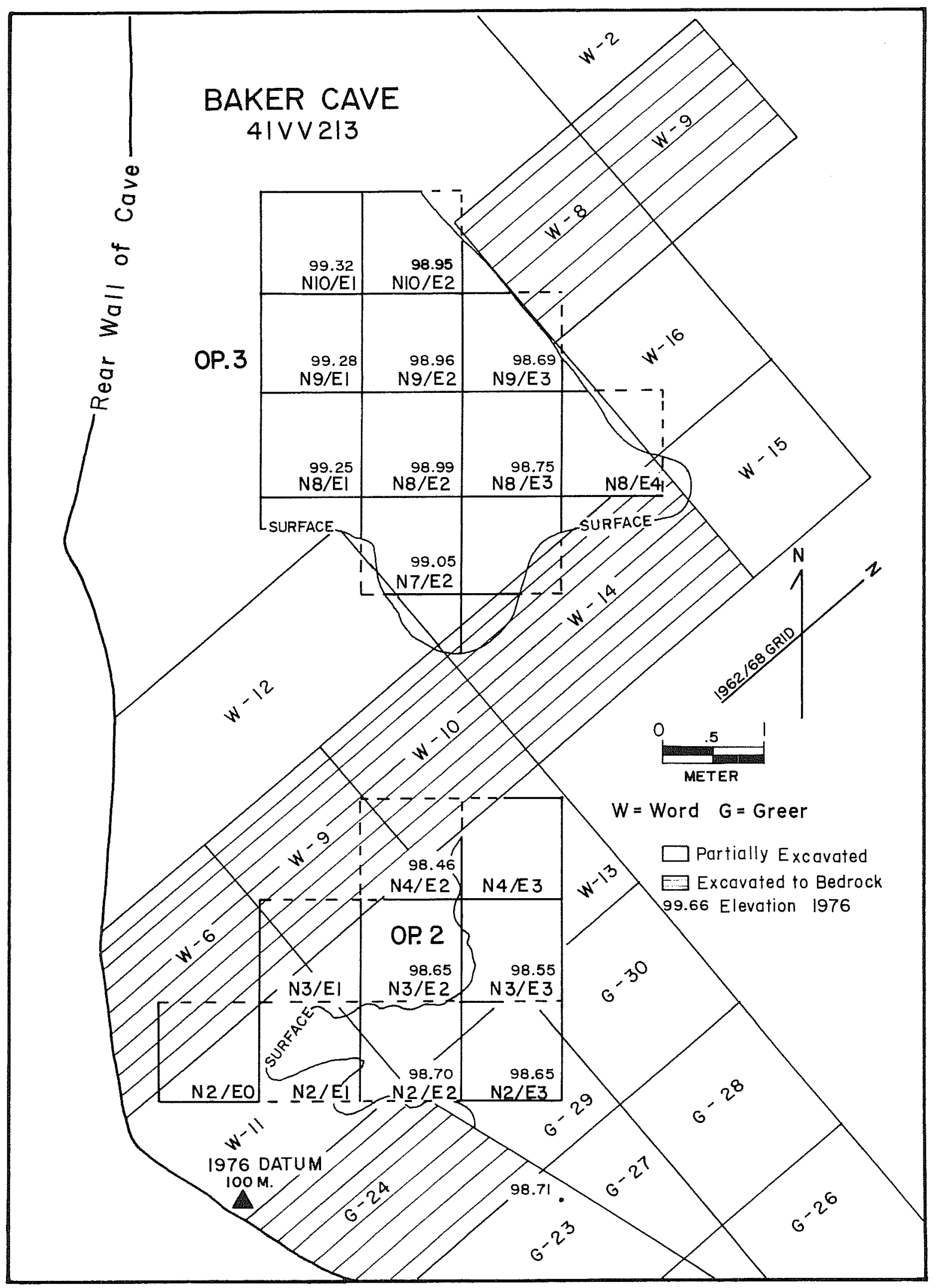

Figure 8. Grid and Surface, 1976 Excavations, Baker Cave. 
consisting of fiber artifacts in the form of sandals, basketry, knotted strands and cordage, a pit containing burned walnut shells, and a variety of lithic tools and debitage. Projectile point types were Langtry and Pandale. At an elevation of $98.42 \mathrm{~cm}$, a pit containing burned rock and cultural material was exposed in the northeast section of N3/E3, extending well into N4/E3. Clearing of this pit revealed that these units were on the edge of a trash midden containing burned rocks, ash, fiber, and Pandale points.

Zone 15 was a thin deposit of fine gray ash and spall overlying a thick layer of fiber designated Zone 15b by both Greer and Hester. The fiber of Zone 15b, up to $15 \mathrm{~cm}$ in thickness in some areas, dipped sharply downward toward the east. To the west, this zone was primarily dust and roof spal1, but cultural material was found throughout. The stake first observed in Zone 12 terminated at this level. Zone 16 was a densely packed fiber deposit extending westward for more than one meter, but terminating abruptly about midway of N2/E2, where rodent burrowing and prior excavation had caused sloughing. Chert tools and debitage were prominent in the artifact assemblage. $A$ second wood stake was noted in N2/E3 at this leve1, which terminated in Zone 17-23, Level 2 at an elevation of 97.86. As described by Greer, this fiber zone overlay a deposit of limestone dust and spal1, revealed in profile to be $15 \mathrm{~cm}$ to $18 \mathrm{~cm}$ thick. Thts zone, unnumbered by Greer, was designated 16b by Hester, and contained numerous flakes, seeds, and charcoal, as well as two Early Triangular points.

Zone 17 marked the appearance of a very 1oose, unconsolidated fil1, characterized by ash, charcoal, and loose fiber, and lacking clear stratification. Greer had reported difficulty in identifying zones in this deposit, and Hester began the excavation of Greer's Zones 17-23 in arbitrary levels of $15 \mathrm{~cm}$. The incidence of rodent burrows and wall collapse became increasingly frequent and, at Level 4, work was temporarily restricted to the one by two meter Unit N2/E2, and the arbitrary level depth was increased to $30 \mathrm{~cm}$. At Leve1 6, Unit N2/E2 was extended westward to include N2/EO and constituted a one by three meter unit, almost in contact with the rear wall.

This unconsolidated deposit was found to have an average thickness of about one meter, reaching $1.25 \mathrm{~m}$ in some areas. Fiber, mostly rotted and scattered, was found throughout, although a few occupational lenses of fiber were present and some partially preserved fragments of basketry. Faunal and floral remains were abundant, the frequency of bones increasing dramatically in Leve1s 4-6 (Wooldridge 1978). Two more round wooden stakes were observed in Level 3 and two stake fragments in Leve1 4. Two large concentrations of walnut she11s were recovered from Level 6. Lithics were present in great quantity, including hammerstones, cores, bifacial and unifacial scrapers, large numbers of secondary and interior flakes, and flake fragments. Early Corner-Notched points, classified by Word as Baker and Bandy types, were recovered from this deposit, as well as points classified as Early Triangular and some lanceolate and stemmed forms, as yet unidentified. An in situ sample of wood charcoal was taken from the profile at an elevation of $98.40 \mathrm{~m}$, near the upper 1 imits of the deposit, and has been radiocarbon dated at $4690 \pm 140$ B.P. . MASCA corrected to $3500 \pm$ 150 B.C. (RL-829). Charles S. Tucek of Radiocarbon Ltd., bases this corrected date on an analysis of tree ring dating made by the University of Pennsylvania Museum (personal communication). A second in situ sample of wood charcoal was taken at an elevation of $97.65 \mathrm{~m}$, near a partially preserved basketry fragment 
in the lower part of this deposit, and has yielded a radiocarbon date of $8080 \pm 80$ B.P., MASCA corrected to 6130 B.C. (TX-2931). In terms of chronological context and artifact assemblage, this deposit relates well to the "Pre-Archaic," as proposed by Hester (1971:119) and defined by Sol1berger and Hester (1972:326-344).

Immediately below the loose, Pre-Archaic fill at an elevation of $97.20 \mathrm{~m}$, a zone of 1 imestone spal1 and dust mixed with gray ash and charcoal was encountered. This gray stratum (designated Leve 7 ) correlates in stratigraphy and appearance with Word's Zone I. At an elevation of about $97.30 \mathrm{~m}$, a dome-shaped area of burned rock was exposed and, beneath it, a large, basin-shaped hearth or cooking pit. The unit was enlarged to include portions of N3/El and N3/E2, so that the entire hearth could be excavated.

The hearth, about $30 \mathrm{~cm}$ in depth, was a wide, irregular oval, lying in a northwest-southeast position, and measuring about $1.20 \mathrm{~m}$ at its greatest diameter. The hearth fill consisted primarily of ash and charcoal, containing great quantities of animal and plant remains (many of them charred), as we 11 as considerable lithic debitage. The fill was bagged in its entirety (about 200 pounds) and transported to the laboratory for intensive study. The bas in of the cooking pit was baked a pink red and, within the fill, discrete areas of ash of different colors suggest separate incidents of fire use over a period of time. At the top of the pit a concentration of large pieces of charcoal (some more than $10 \mathrm{~cm}$ in width) indicated that a fire had been smothered by the rocks which were found capping the hearth and effectively sealing it within this stratum (Fig. 9). Results of a preliminary pollen scan and identification of plant remains from the hearth fill are presented in Table 6 . Identification of animal remains is given in Table 8.

At the southwestern periphery of the hearth, the base of a Golondrina point was recovered at an elevation of $97.08 \mathrm{~m}$, and a sample of wood charcoal directly underlying it was taken. A radiocarbon assay on this charcoal has assigned it a date of $9020 \pm 150$ B.P. (7070 B.C.; Tx-2466). About $45 \mathrm{~cm}$ to the east and nearer to the hearth, an unfinished biface, which may be a Golondrina preform, was recovered at an elevation of $97.20 \mathrm{~m}$. A sample of wood charcoal taken near it, within the hearth, at an elevation of $97.02 \mathrm{~m}$ has been given a radiocarbon date of $9180 \pm 220$ B.P. (7230 B.C.; RL-828). Lying about $20 \mathrm{~cm}$ outside the eastern limits of the hearth, a triangular, bifacial tool of the Clear Fork type was found at an elevation of $97.13 \mathrm{~m}$. This association is the first firm, excavated evidence that this fairly common adzelike implement was a part of the Golondrina complex tool assemblage. A tool made on a blade, which may have served as a knife or scraper, and an unfinished biface were found in this stratum, in addition to a hammerstone, a core fragment, and numerous flakes.

After removal of the hearth and its contents, Level 7 was excavated to a depth of about $97 \mathrm{~m}$ elevation, and the unexcavated portion which had been left as a balk in N2/E2 was taken down to that level. The basal spall underlying this stratum was designated Leve1 8 and was excavated to bedrock in the one by three meter trench of N2/E2 and the adjacent fragmentary portions of N3/E1 and N3/E2. The maximum thickness of this level was $60 \mathrm{~cm}$, and the fill was primarily of limestone dust and spal1. A large rodent disturbance, containing many rodent bones, was exposed, and chert debitage, charcoal, and a turtle plastron were recovered. Several pieces of partially decomposed wood were 


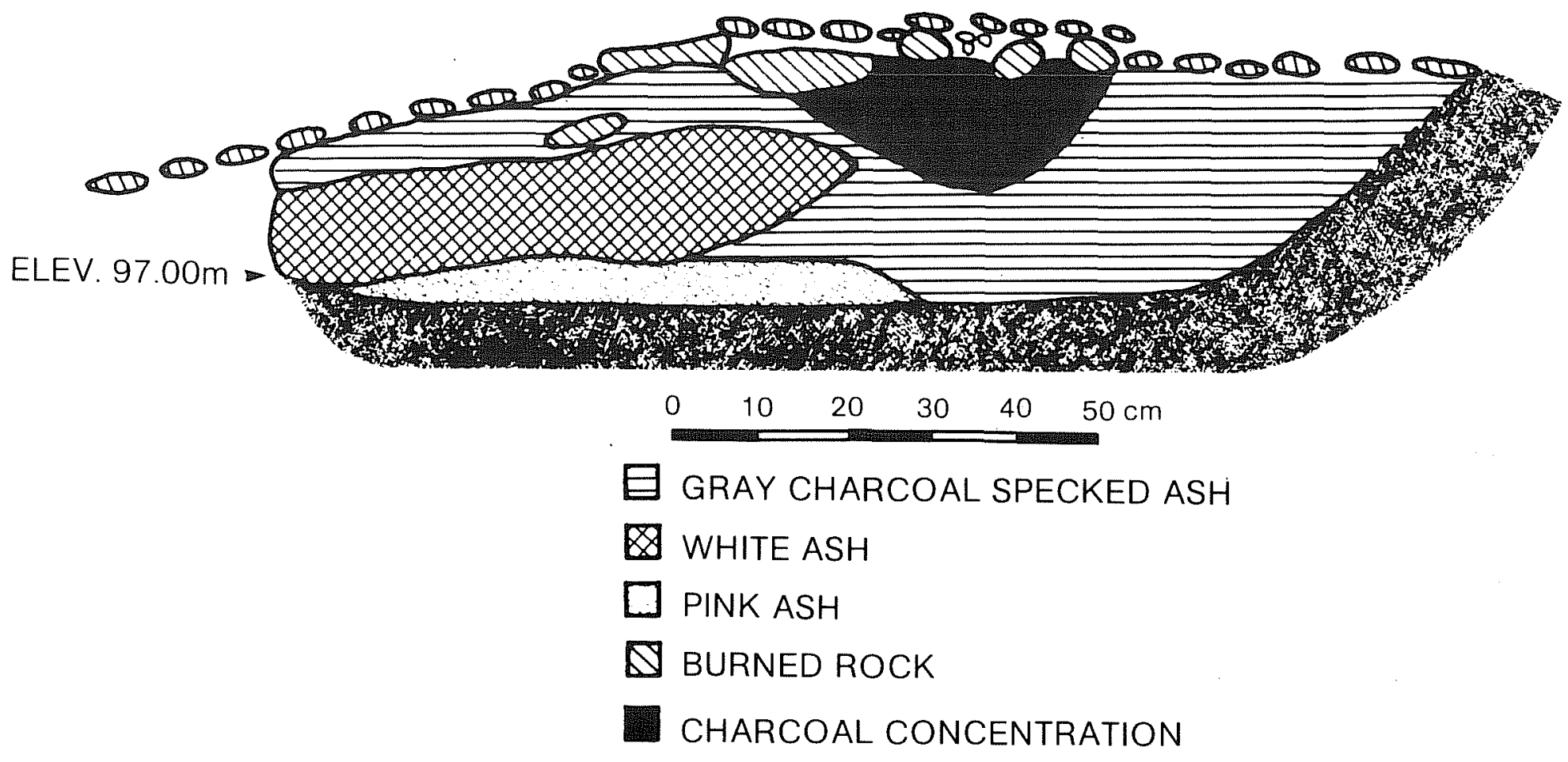

Figure 9. North Profile of Hearth in Golondrina Zone, Operation 2, Zones 17-23, Level 7, Baker Cave, 1976 Excavations. Courtesy of Thomas R. Hester. 
found in a concentration near the large rodent burrow and may represent the remains of a Pleistocene packrat house, although this is not verified. The feature rests on an irregular natural ledge which forms a shallow trough in the bedrock. A definite color change from white to light brown was noted in the matrix near the rodent disturbance, indicating possible decomposition of wood or fiber from moisture accumulation in the depression. One large piece and some fragments of wood were bagged and removed, and the remainder left in place, protected by a structure of boards and plastic.

No clear evidence of human occupation was found in Level 8, and it is believed that any cultural material from this portion of the basal zone is intrusive. The maximum depth reached in Level 8 was at an elevation of $96.30 \mathrm{~m}$ (Fig. 10). Frequency and distribution of artifacts from Operation are shown in Table 2.

\section{Operation 3}

The area selected for horizontal excavation is an irregularly shaped "peninsula" at the back of the shelter, bounded on the south and east by trenches from Word's excavations. Viewed in profile, these trenches reveal a stratigraphic pattern of fiber alternating with 1 imestone dust. The surface sloped from west to east (back to front) rather sharply at an angle of $25^{\circ}$, and gradually from north to south at a grade of $15^{\circ}$ to $20^{\circ}$. A grid of 10 one-meter squares was laid out in a north-south direction, corresponding in orientation and numerical sequence to that for Operation 2, which was directly to the south across the existing trench. Because of the irregular nature of the excavation area, large portions of some of the units were missing (Figs. 8 and 11).

Excavation was done by removal of natural strata as they occurred over the entire area. No balks were left between units but the deeply sunk corner stakes provided horizontal and vertical control. Excavation reached a maximum depth of $75 \mathrm{~cm}$ below surface, roughly equivalent in depth to Word's Zones IV and $V$. Strata were described as Zones 1-8, but this is an internal designation for this operation and bears no relationships to zone numbers used by either Word or Greer.

Because of the unstable nature of the matrix and the steep angle of west to east slope, it was found necessary to excavate from the highest point downward, resulting in some compaction of the lower squares before they could be examined. Since workers from previous excavations had also used this area as a walkway, it seems likely that the alternating layers of fiber and dust are today more compressed than when originally deposited. Indeed, the stratigraphy exposed in the east profile of the block resembles fine Danish pastry in its appearance, with the fiber strata separated only by slight lenses of dust.

For convenience of description, the term "Row 8 " is used to define the adjacent east-west squares N8/E1, N8/E2, and N8/E3. Similarly, "Row 9" refers to the

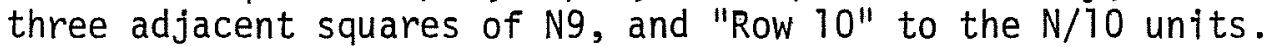

The surface deposit (Zone 1) of limestone dust, spa11, and sheep dung varied in thickness from $4 \mathrm{~cm}$ to $8 \mathrm{~cm}$, tapering off toward the east to a light powdering. The appearance of fiber in scattered or dense form indicated the beginning of 


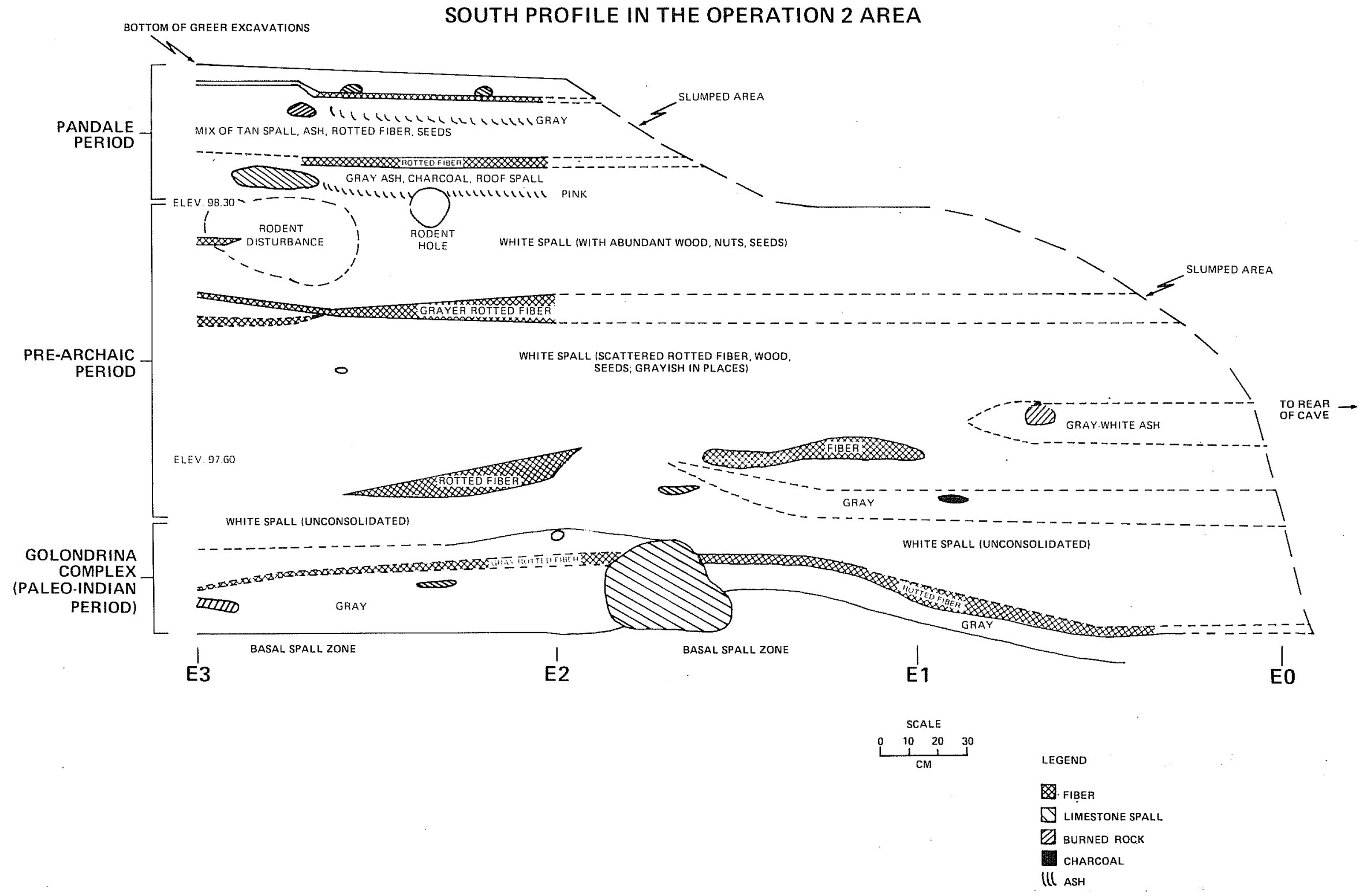

Figure 10. Profile of North Wall, Operation 2, Baker Cave, 1976 Excavations. Courtesy of Thomas R. Hester. 
TABLE 2. FREQUENCY AND DISTRIBUTION OF ARTIFACTS, OPERATION 2, BAKER CAVE

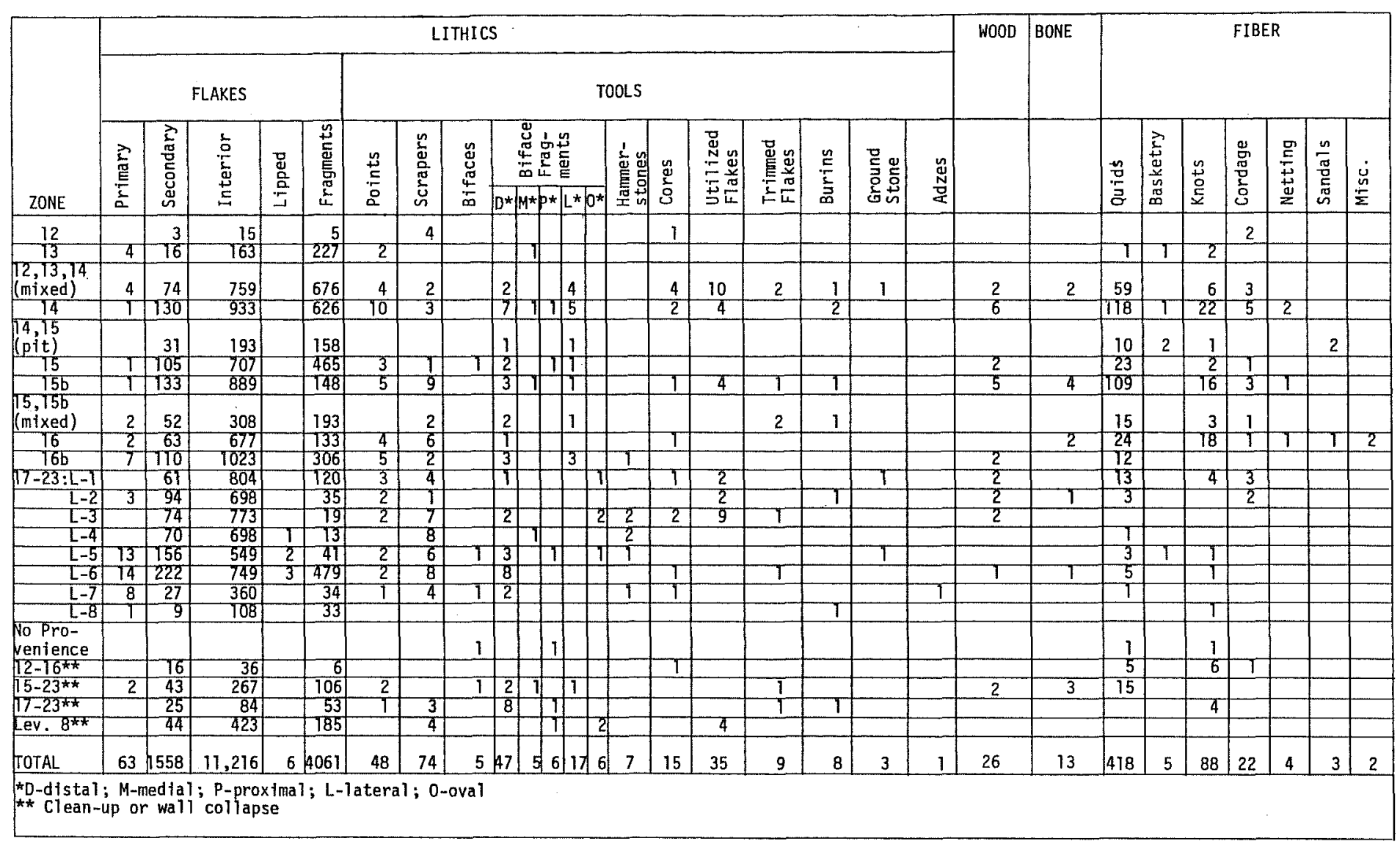




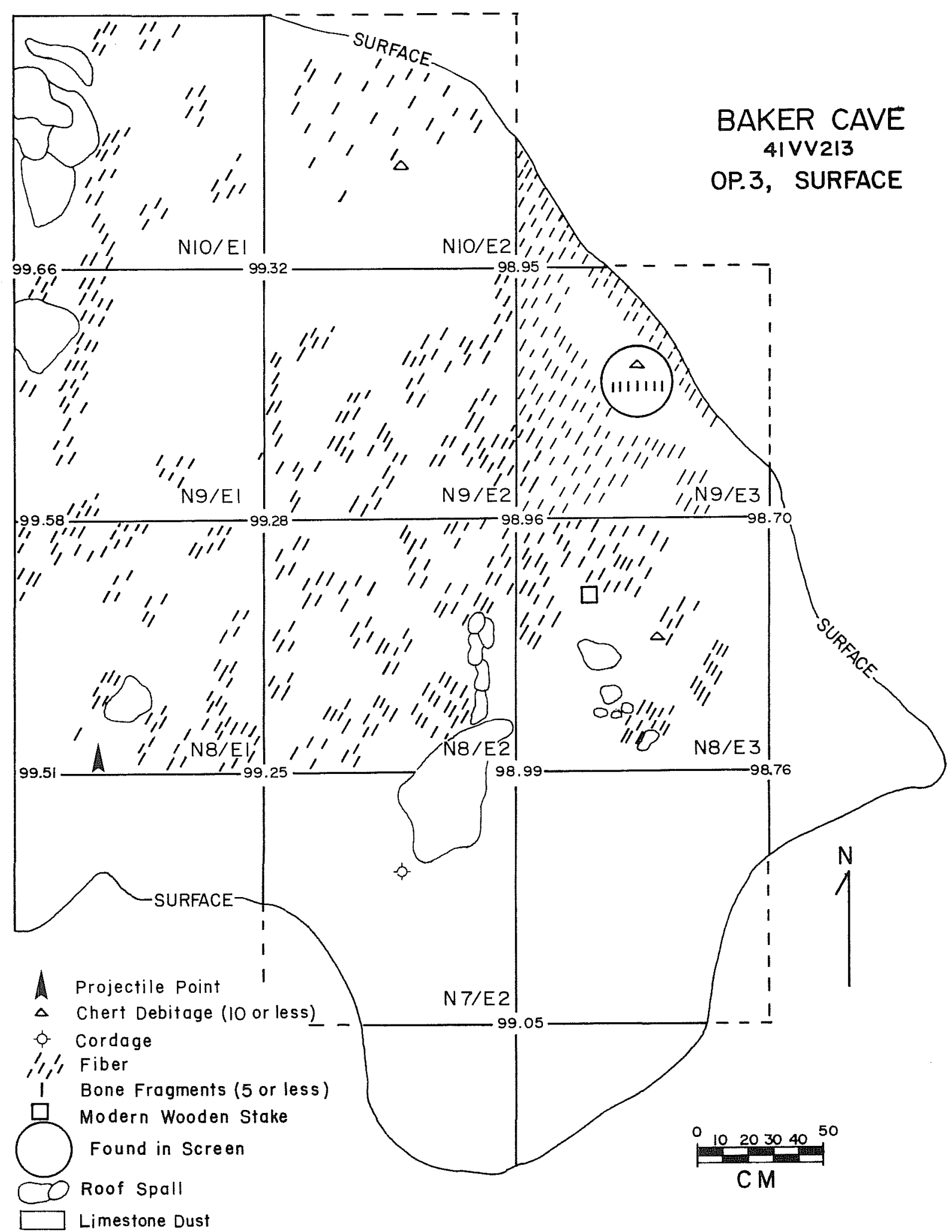

Figure 11. Grid and Surface, Operation 3, Baker Cave. 
Zone 2, and al1 squares were cleared of dust and were mapped before proceeding. Artifacts found in Zone 1 included one projectile point of the Langtry type (Fig. 11).

The first fiber layer (Zone 2) was fairly well defined in the two westernmost squares of Rows 8 and 9 , tapering off at the beginning of the third square. In Row 8, the fiber increased in thickness from four centimeters on the west to $10 \mathrm{~cm}$ in the second square. In Row 9 it maintained a fairly constant thickness of $10 \mathrm{~cm}$, following the downslope for the first two meters. In Row 10, Zones 2 and 3 were both fiber of varying density and extended only partially into the second square, which had been reduced by prior excavations. Although the units to the east, shown as unexcavated in Figure 12, were also of fiber, they were clearly perceived in profile to lie stratigraphically below the fiber of Zone 2 and did not engage with it during removal.

Zone 3 was initially recognized in the west square of Row 8 as a five centimeter to six centimeter deposit of ashy dust, but loose fiber soon appeared in varying amounts and the zone merged into the thicker fiber of underlying Zone 4 at the beginning of the second square. In Row 9, Zone 3 was more clearly defined as ashy dust, continuing well into the second square. As noted above, in Row 10, Zone 3 contained much loose fiber and was barely discernible from Zone 2 . It, too, disappeared near the end of the first square. Among the artifacts from Zone 3 was an arrow point of the Perdiz type (Fig. 13).

Zone 4 was a well-defined layer of fiber, about $10 \mathrm{~cm}$ thick on the west wall of Row 8, joining and tapering off into the layer below at the beginning of the second square. In Row 9 it was clearly defined between the dust zones of 3 above and 5 below, beginning with a thickness of about $10 \mathrm{~cm}$ and leveling to zero about $60 \mathrm{~cm}$ from the west wal1. In Row 10 the extent of Zone 4 was about the same as in Row 9, but the fiber was scattered and less dense. At the southwest corner of the west wall of Zone 4 was a dense accumulation of burned fiber and ashy residue, the ash extending some $30 \mathrm{~cm}$ east in Row 9 (Fig. 14).

Zone 5 varied widely in the excavated area and indicates a shift in occupation to the north. In Row 8 we removed $18 \mathrm{~cm}$ of dust from the west wall before encountering fiber Zone 6. Excavation at this level was continued eastward for $90 \mathrm{~cm}$ until we detected fiber converging from the lower strata. About midway of Unit N8/E1, a large nestlike ball of fine fiber was discovered, and we lowered the level in order to remove it intact. Zone 5 of Row 9 was a dust 1 ayer $10 \mathrm{~cm}$ deep at the west wall, and we continued almost horizontally at this level for approximately $80 \mathrm{~cm}$. At this distance, the fiber layer appeared and began to slope with the downgrade. In contrast, the dust in Zone 5 in Row 10 was only five to six centimeters thick, tapering gradually to give way to fiber about $90 \mathrm{~cm}$ east of the west wa11. The dense clump of burned fiber found in the west wall of Zone 4 was continued into Zone 5 (Fig. 15).

Zone 6 represents the reverse of the Zone 5 stratigraphy. In Row 8 a dense fiber mass five to eight centimeters thick extended from the west wall eastward about $25 \mathrm{~cm}$. Fiber again appeared about $80 \mathrm{~cm}$ eastward and continued at a depth of $10 \mathrm{~cm}$, thinning out and leveling off at the beginning of the third square. In Row 9 this zone was $10 \mathrm{~cm}$ to $12 \mathrm{~cm}$ deep at the west wall and continued at this thickness for about $80 \mathrm{~cm}$, when it, too, began following the downgrade and 


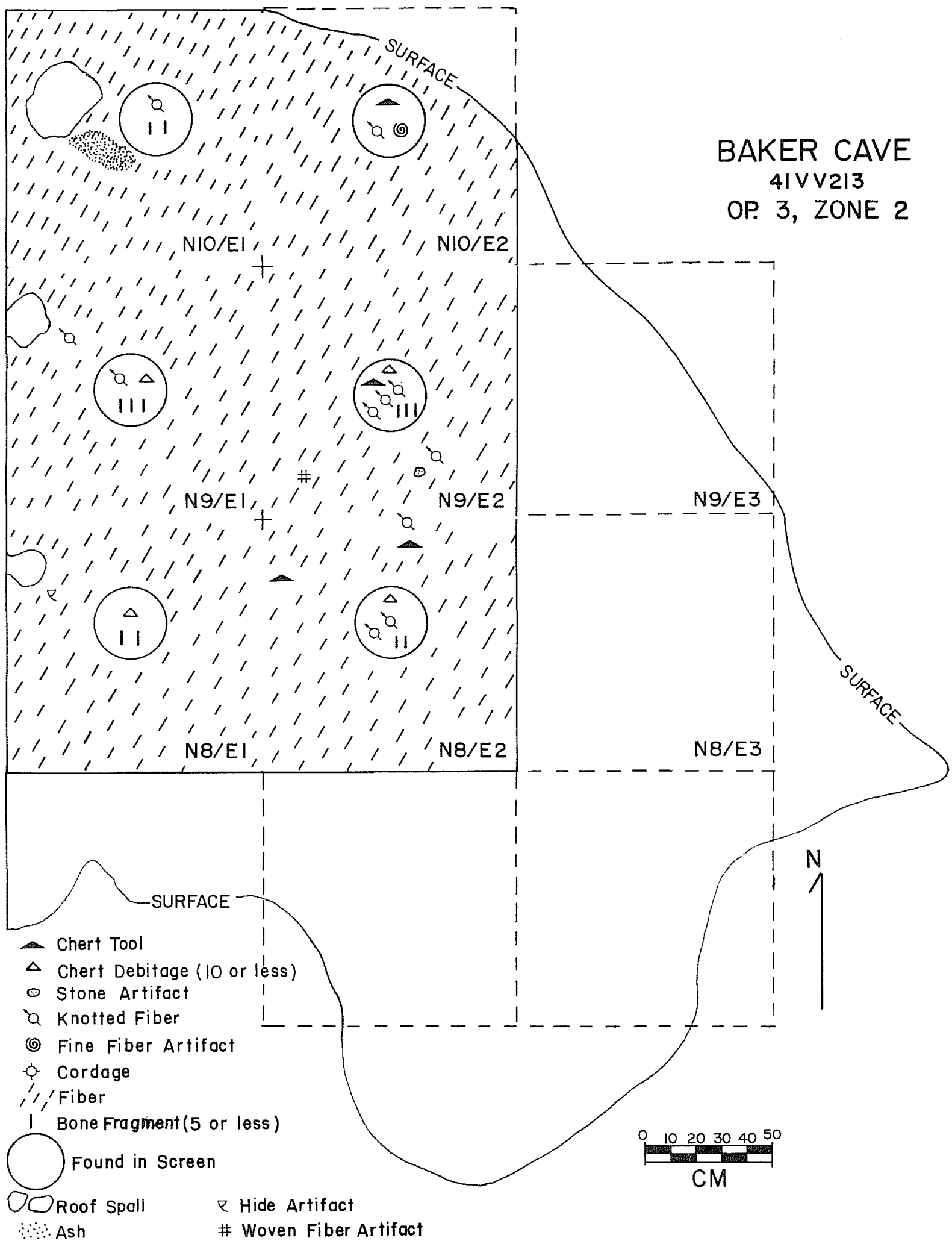

Limestone Dust

Figure 12. Excavated Areas of Zone 2, Operation 3, Baker Cave. 


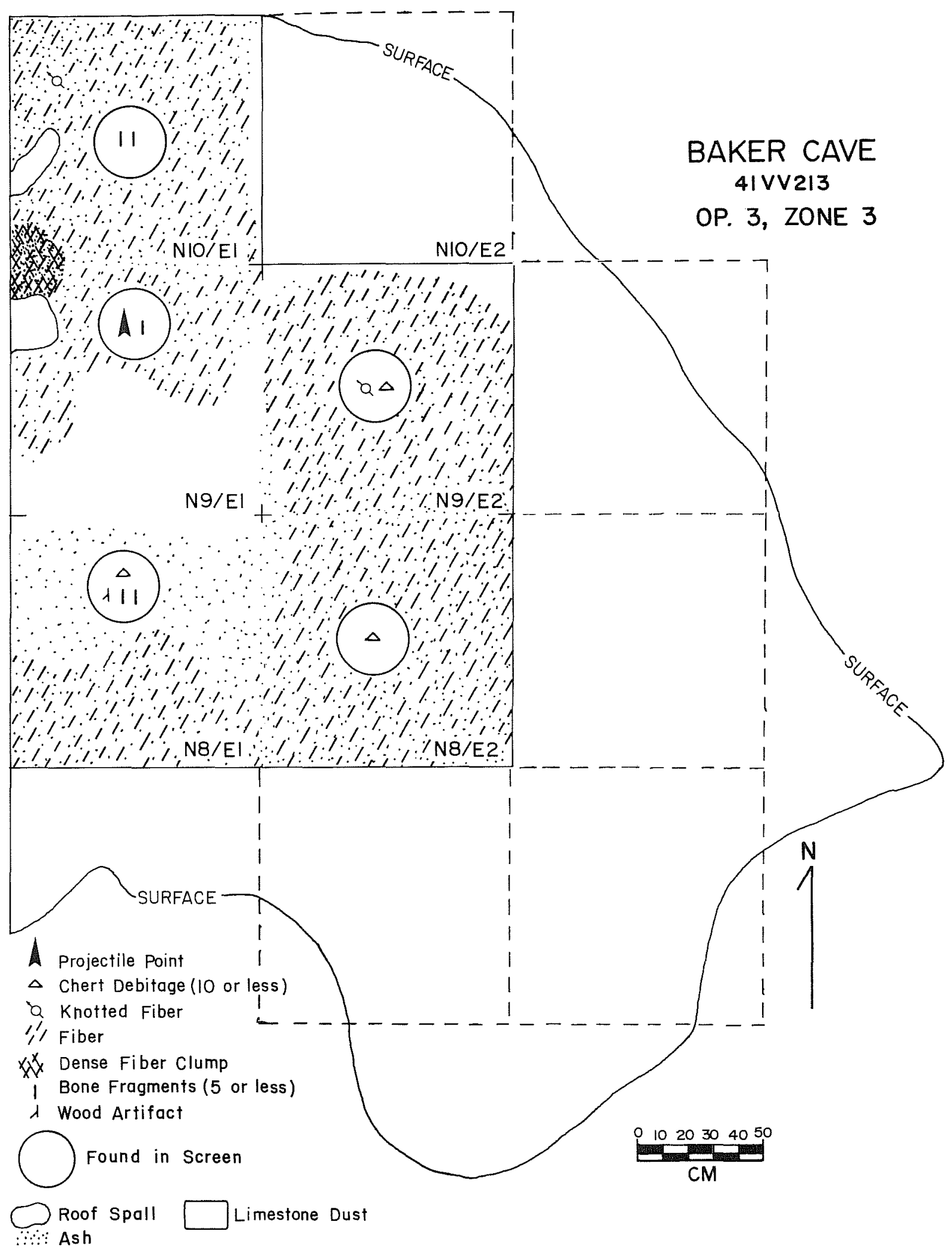

Figure 13. Excavated Areas of Zone 3, Operation 3, Baker Cave. 


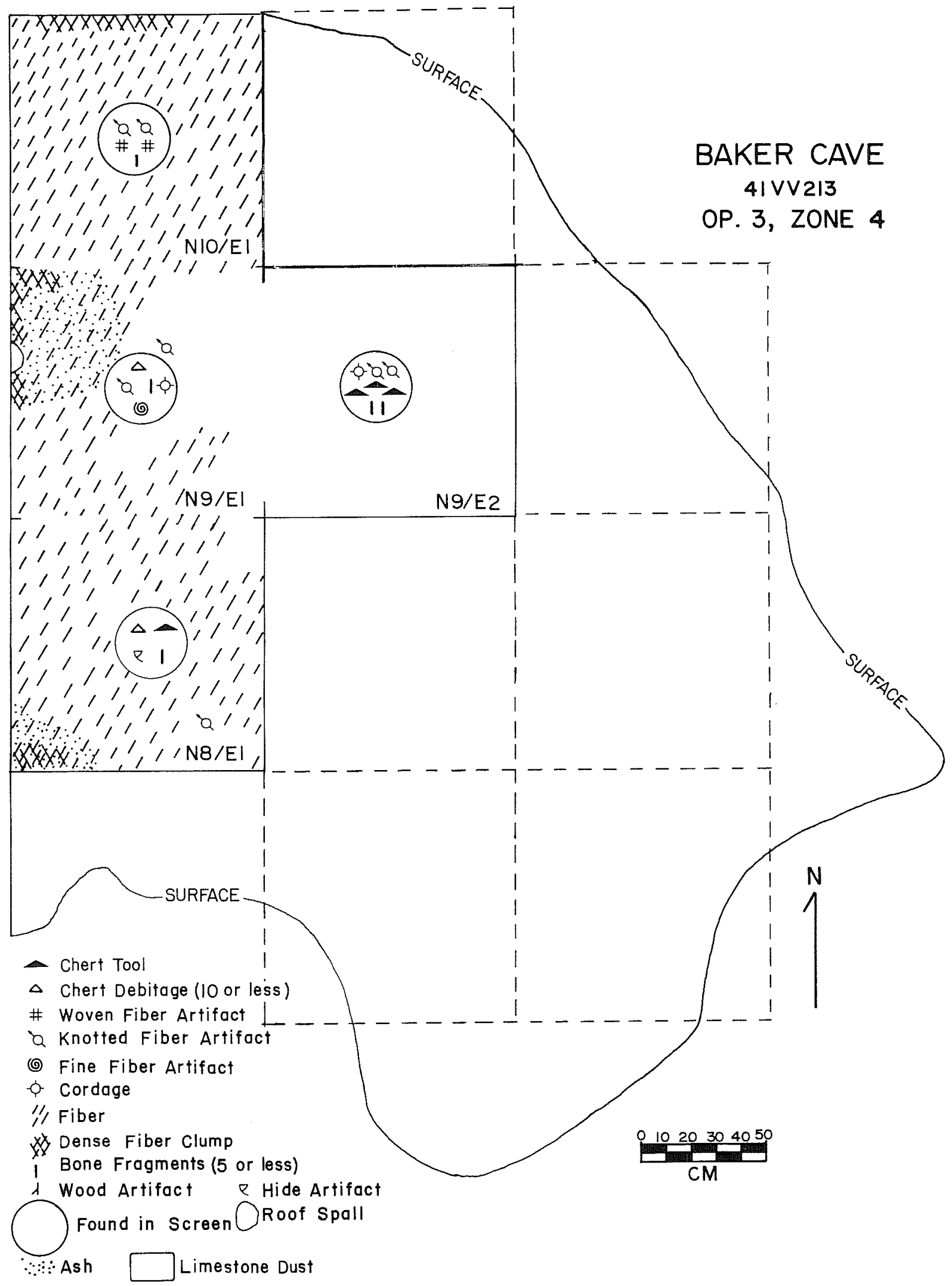

Figure 14. Excavated Areas of Zone 4, Operation 3, Baker Cave. 


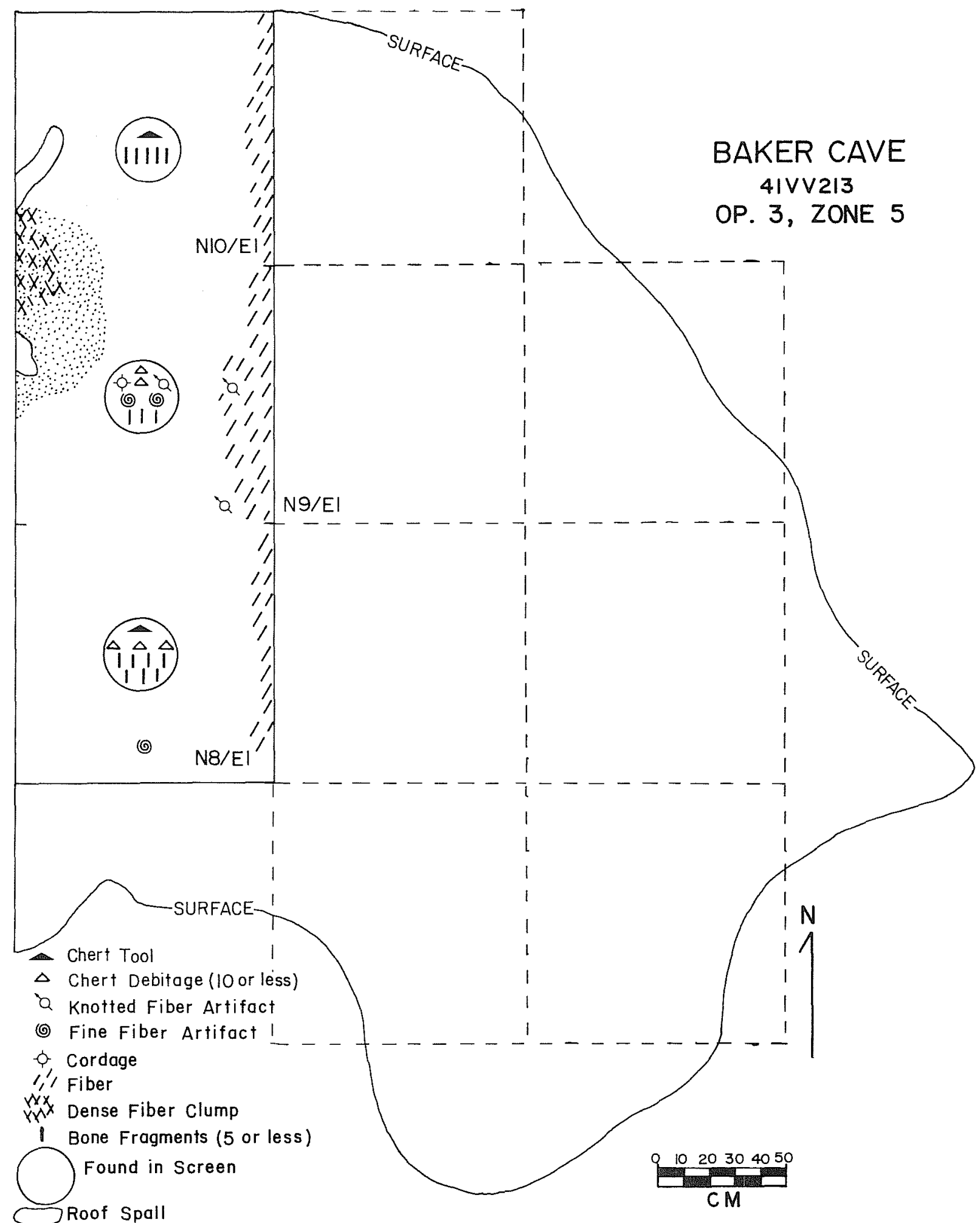

Roof Spall

Ash $\square$ Limestone Dust

Figure 15. Excavated Areas of Zone 5, Operation 3, Baker Cave. 
thinning out near the beginning of the third square. In Row 10, Zone 6 reached a depth of $17 \mathrm{~cm}$ to $18 \mathrm{~cm}$ at the west wal1 and revealed the extent of the burned fiber clump in the west wal1, first observed in Zone 4. The bottom of Zone 6 in both Rows 9 and 10 appeared to follow an almost horizontal level eastward for $90 \mathrm{~cm}$ to $100 \mathrm{~cm}$ and then to take the $25^{\circ}$ angle downward, gradually lessening in thickness for the distance of another meter. Particularly in Row 10 was this pattern we11 defined (Fig. 16).

Zone 7 was an arbitrarily defined level of a $15 \mathrm{~cm}$ to $17 \mathrm{~cm}$ deposit of dust at the west wa11. Its depth was determined by the appearance in Row 9 of an underlying fiber layer beginning about $160 \mathrm{~cm}$ east of the west wall. In Row 10 its depth coincided with the bottom of a round wooden stake, $20 \mathrm{~cm}$ in length, which had been exposed embedded in the west wal1 through Zone 6 . Plotting of the position of this stake indicates that it bears no relation to Word's Feature 4 (Word and Douglas 1970:19; Fig. 9) in which stalks had apparently been placed in an arc on one side of a large block of roof spall. Except for a clump of burned fiber near the base of this stake, Zone 7 of Row 10 was primarily of limestone dust and was terminated when a fiber zone appeared below it $35 \mathrm{~cm}$ into the second square. Zone 7 within Row 8 was excavated at a horizontal level to conform to that of Rows 9 and 10 and was primarily a thick layer of dust eastward for $1.5 \mathrm{~m}$. At this distance, thick fiber deposits and a well-formed hearth about $25 \mathrm{~cm}$ in diameter were encountered. A cone-shaped hole had been dug to a depth of $21 \mathrm{~cm}$ and charcoal filled it to a depth of $10 \mathrm{~cm}$. Flat stones rested on the charcoal and upright, slanted stones formed a well-fitted circle about them. The hearth was exposed, photographed, and sketched, and then removed. In an effort to recover material related to the hearth, the adjacent square in Row 7 was partially excavated at this level (Fig. 17). Cultural material was abundant in Zone 7, including two projectile points, one classified as Ensor and one of the type designated by Word as Langtry II (Word and Douglas 1970:28).

The excavation of Zone 8 was controlled by the first opportunity to remove a unified layer of fiber extending to the easternmost profile of the block. The removal of the hearth first observed in Zone 7 had lowered that unit in Row 8 well into fiber Zone 8 , but it was possible to lift off the remaining fiber fairly well intact. In Row 9, the fiber. layer of Zone 8 became apparent only $35 \mathrm{~cm}$ from the west wall, deepening as it approached the hearth area until it reached a depth of $17 \mathrm{~cm}$. The hearth depression was not present in Row 10, the fiber merely following the downward slope, leveling off at the same depth as that of Rows 8 and 9, but truncated on the east (Fig. 18). Artifacts of fiber and hide, including two sandals and many chewed quids, were the most abundant cultural materials recovered from this zone. Frequency and distribution of artifacts from Operation 3 are presented in Table 3.

Excavation of Operation 3 was terminated on the west wall at a depth of $75 \mathrm{~cm}$ from the surface (Fig. 19). Clearing of the hearth depression and surrounding fiber in Zone 8 , however, lowered this depth on the east by $10 \mathrm{~cm}$ to $15 \mathrm{~cm}$. The bottom of the hearth in Zone 8 , at an elevation of $98.70 \mathrm{~m}$, represents the earliest incidence observed in Operation 3 of a preserved fiber layer apparently placed for some purpose. Fiber related to the hearth extended northward through the ful1 three-meter area, but was thicker and deeper in the vicinity of the hearth (Fig. 20). 


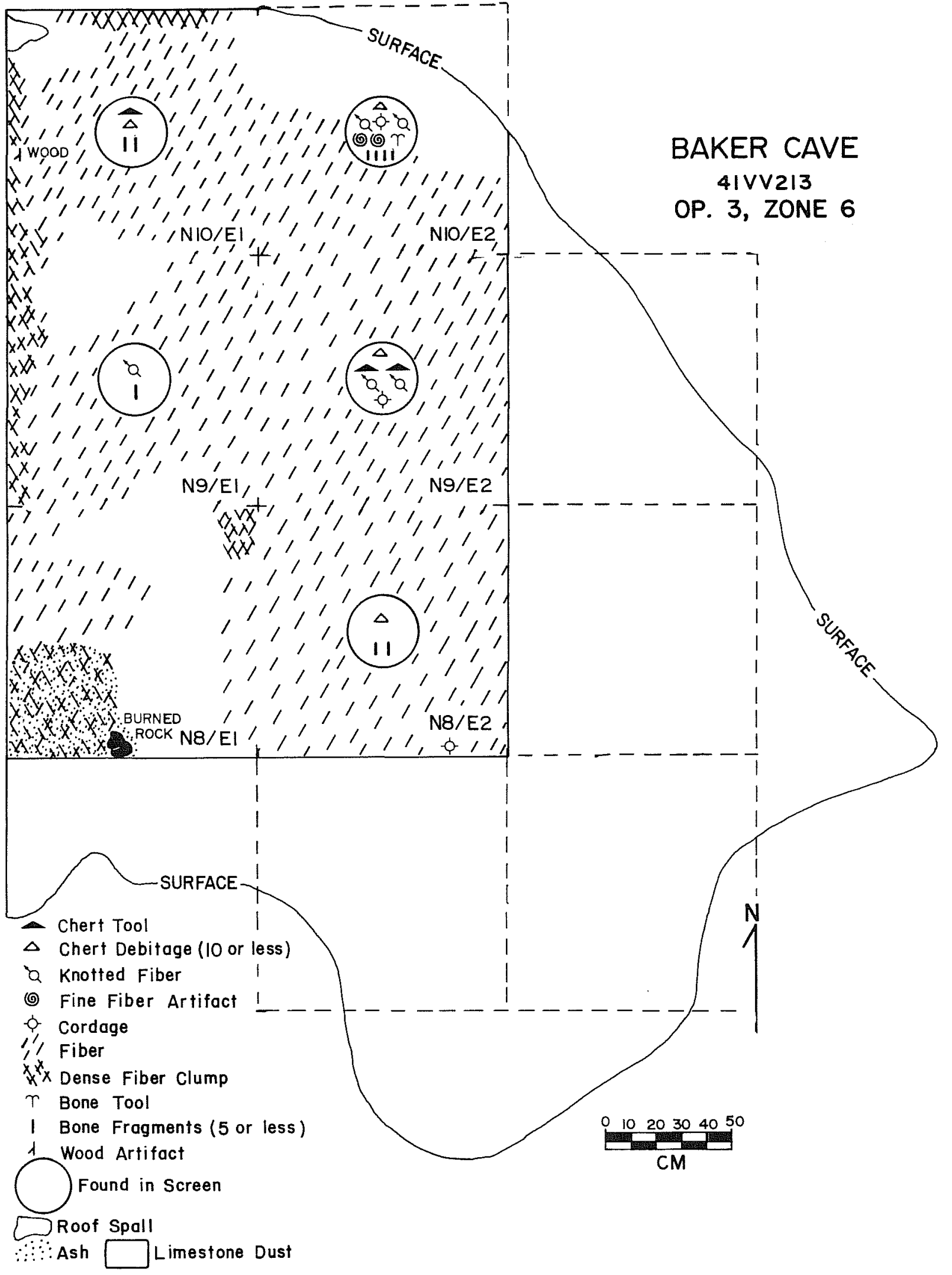

Figure 16. Excavated Areas of Zone 6, Operation 3, Baker Cave. 


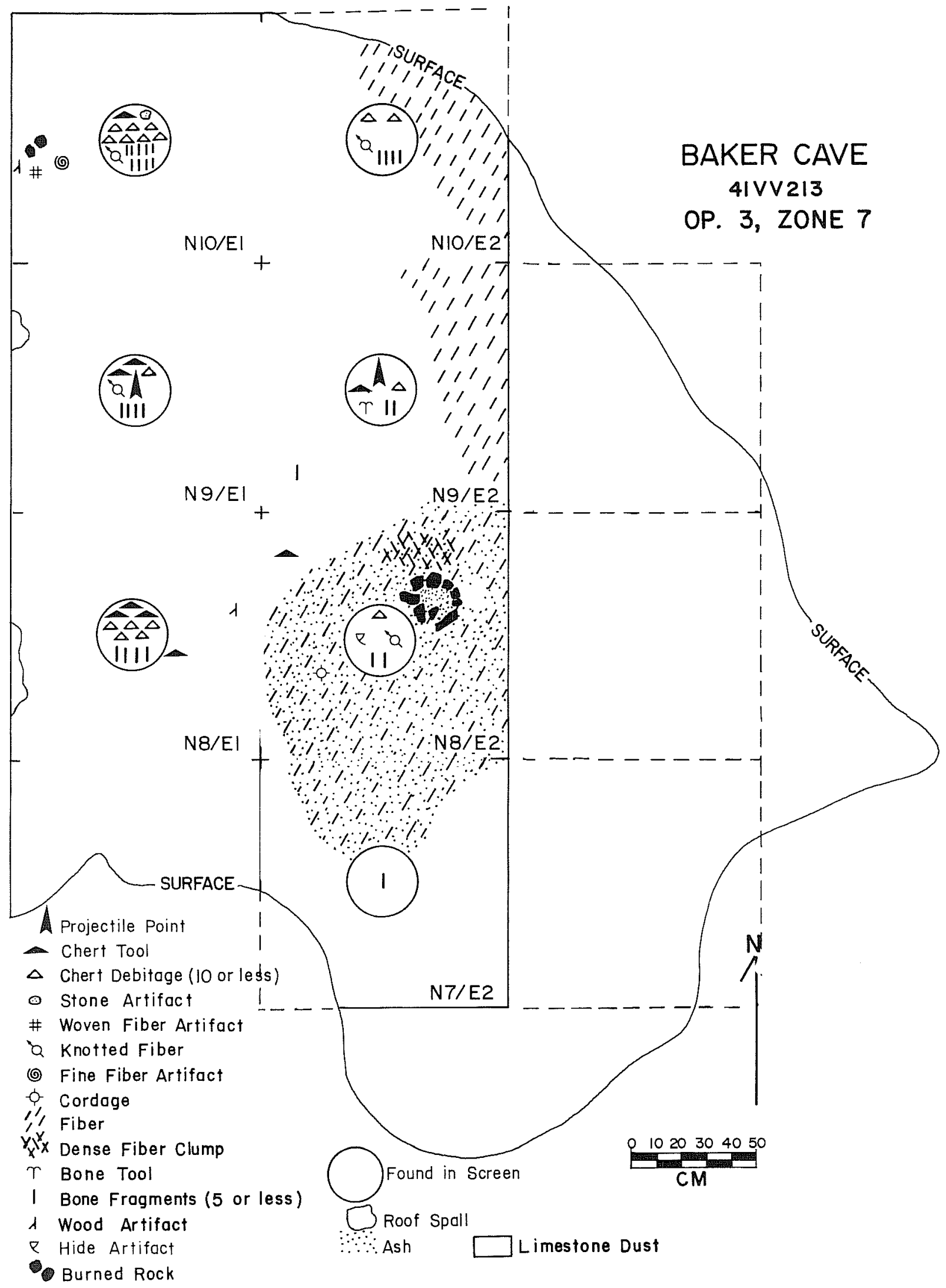

Figure 17. Excavated Areas of Zone 7, Operation 3, Baker Cave. 


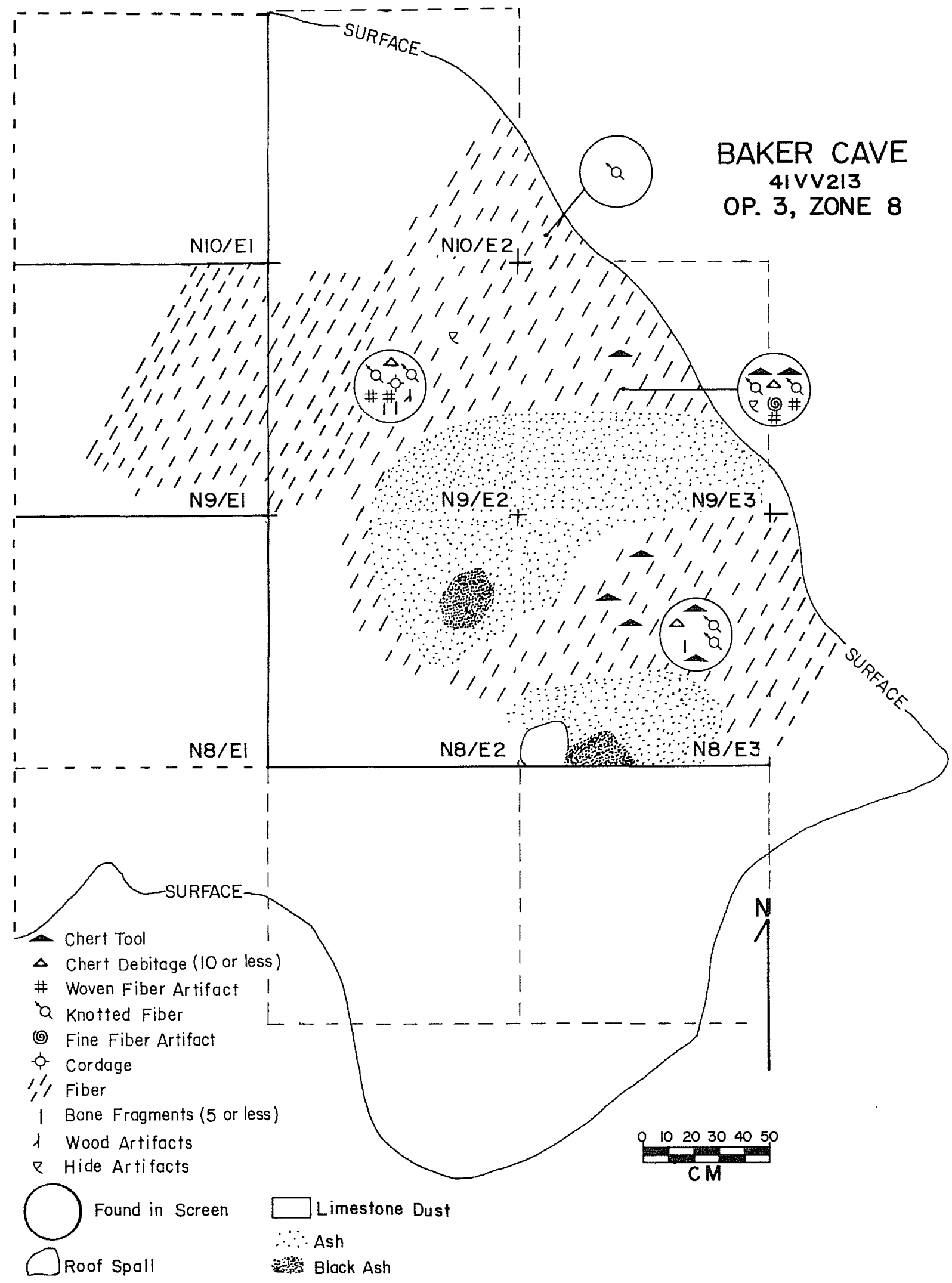

Figure 18. Excavated Areas of Zone 8, Operation 3, Baker Cave. 
TABLE 3. FREQUENCY AND DISTRIBUTION OF ARTIFACTS, OPERATION 3, BAKER CAVE

\begin{tabular}{|c|c|c|c|c|c|c|c|c|c|c|c|c|c|c|c|c|c|c|c|c|c|c|c|c|}
\hline \multirow[b]{3}{*}{ ZONE } & \multicolumn{13}{|c|}{ LITHICS } & \multirow[t]{3}{*}{ WOOD } & \multirow[t]{2}{*}{ HIDE } & \multirow[t]{3}{*}{ BONE } & \multirow{2}{*}{\multicolumn{8}{|c|}{ FIBER }} \\
\hline & \multicolumn{5}{|c|}{ FLAKES } & \multicolumn{8}{|c|}{ TOOLS } & & & & & & & & & & & \\
\hline & 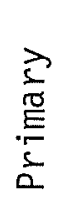 & $\begin{array}{l}\vec{D} \\
\frac{\pi}{0} \\
\overline{0} \\
\bar{d} \\
\ddot{N}\end{array}$ & 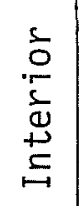 & $\begin{array}{l}\stackrel{0}{d} \\
\stackrel{0}{\Omega} \\
\stackrel{\square}{a}\end{array}$ & 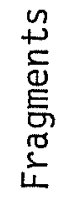 & 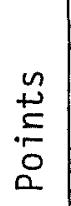 & $\begin{array}{l}\frac{n}{2} \\
\frac{0}{0} \\
\frac{0}{u} \\
\tilde{n}\end{array}$ & 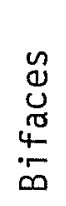 & 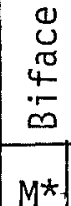 & & 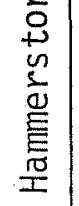 & 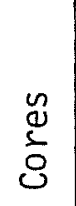 & 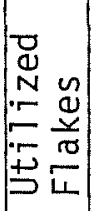 & & & & $\frac{\frac{n}{8}}{\frac{D}{8}}$ & 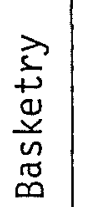 & $\begin{array}{l}\stackrel{n}{+} \\
\stackrel{0}{\frac{1}{2}}\end{array}$ & 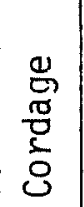 & 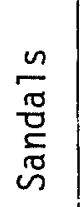 & $\begin{array}{l}\stackrel{n}{n} \\
\stackrel{y}{z}\end{array}$ & 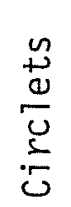 & i \\
\hline 1 & & & 2 & 1 & 1 & 1 & 1 & & & & & & & & & & 3 & 1 & & 1 & & & & \\
\hline 2 & & 3 & 5 & 3 & 6 & & 1 & $\cdot$ & 1 & & & & 4 & 1 & 1 & & 73 & 1 & 11 & & & & 1 & \\
\hline 3 & & 1 & 4 & 2 & 1 & 1 & & & 1 & & & & & 1 & & & 15 & & 2 & & & & & \\
\hline 4 & & 5 & 3 & 1 & 10 & & 1 & & & & & & 3 & 1 & 1 & & 34 & 2 & 7 & 2 & & & 2 & \\
\hline 5 & 1 & 8 & 9 & 8 & 13 & & & & & 1 & & & 1 & & & & 9 & & 3 & 1 & & $i$ & 2 & \\
\hline 6 & & 2 & 9 & 2 & 2 & & & & 1 & & & & 1 & & & 1 & 25 & & 4 & 2 & & & 2 & \\
\hline 7 & & 12 & 54 & 8 & 47 & 2 & & 1 & & & 1 & 1 & 2 & 2 & 1 & 1 & 46 & & 4 & 1 & & 1 & & 2 \\
\hline 8 & & 4 & 4 & 2 & 9 & & 2 & 1 & & & & 1 & 4. & 1 & 2 & & 123 & 2 & 6 & 1 & 2 & 1 & & \\
\hline $\mathrm{NP}$ & & & & & & & & & & & & & & & & & & & & 1 & & & & \\
\hline TOTAL & 1 & 35 & 90 & 27 & 83 & 4 & 5 & 2 & 3 & 1 & 1 & 2 & 15 & 6 & 5 & 2 & 288 & 6 & 37 & 9 & 2 & 3 & 7 & 2 \\
\hline
\end{tabular}




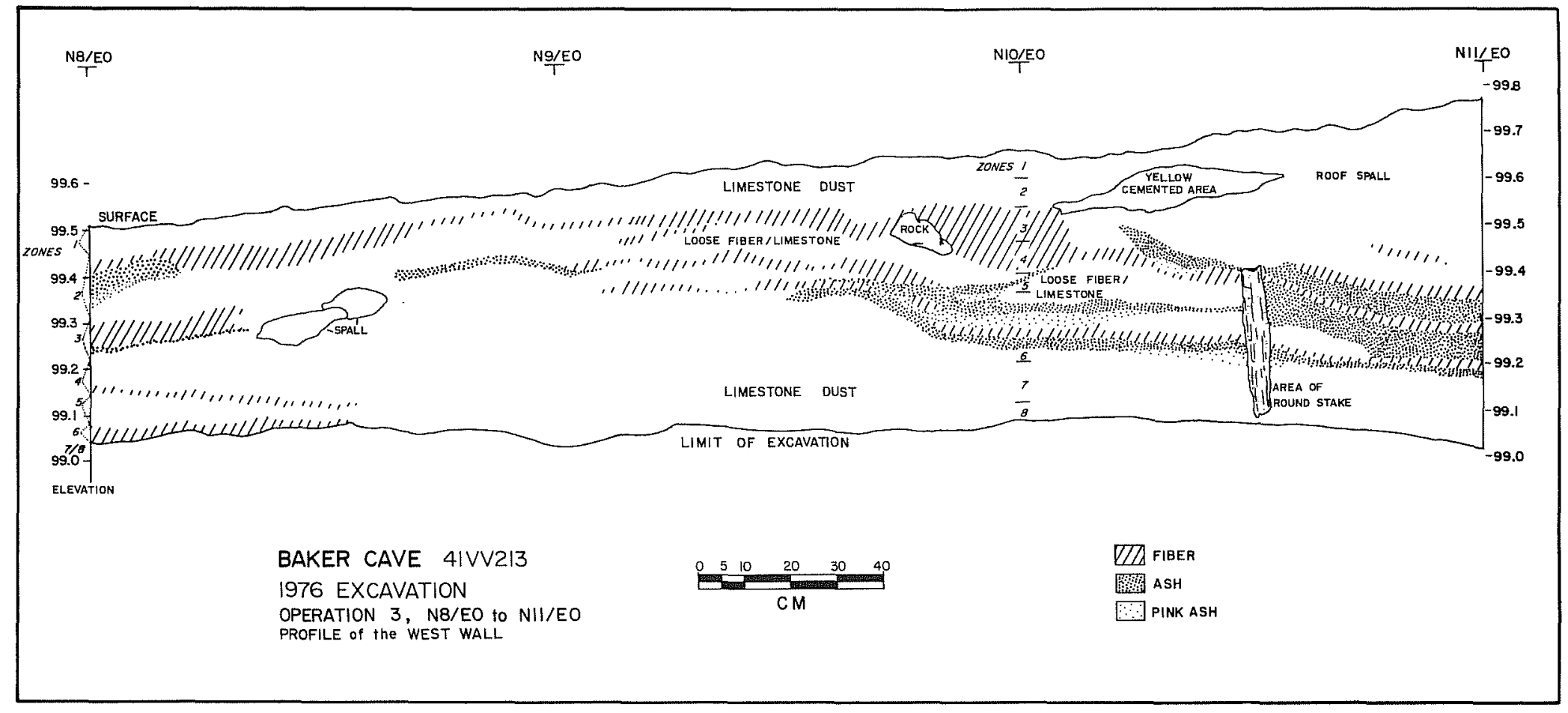

Figure 19. Profile of West Wall, Operation 3, Baker Cave, 1976 Excavations. 

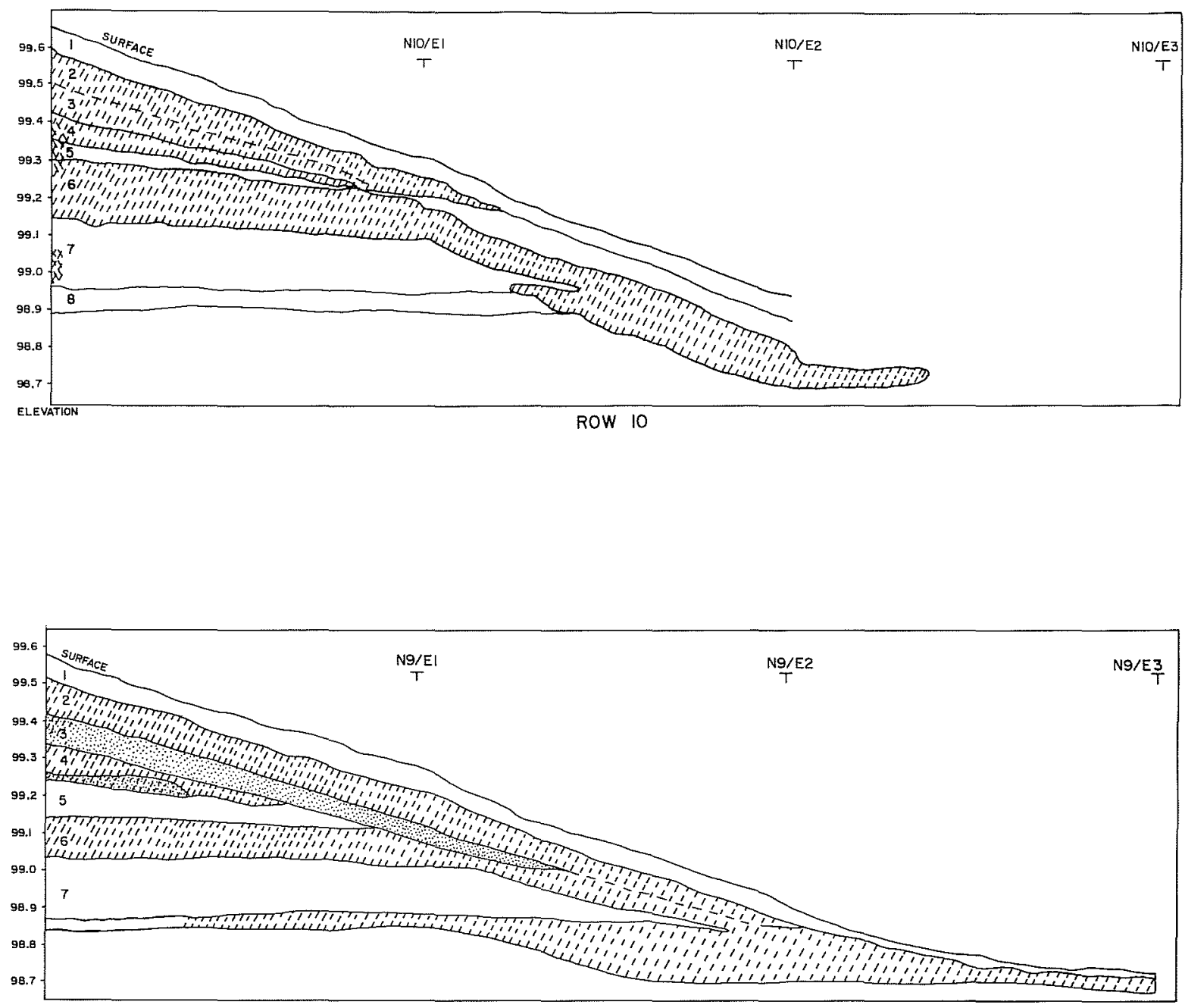

ROW 9

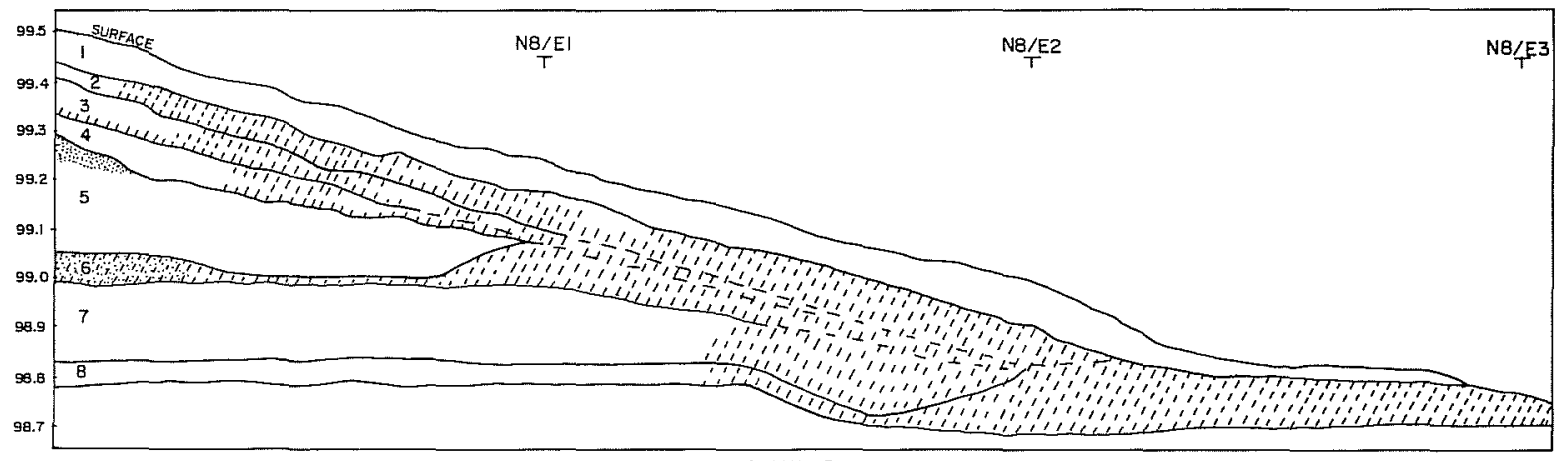

ROW 8

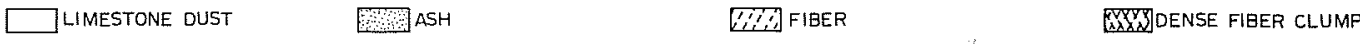

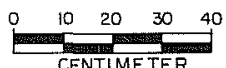

CENTIMETER

Figure 20. Reconstructed Cross Section of Rows 8, 9, and 10, Operation 3, Baker Cave. 
The greatest disparity in thickness and regularity of the alternating deposits was noted in Zones 5 and 6 . The fact that the surface of Row 10 was $15 \mathrm{~cm}$ higher on the west wall than that of Row 8 accounts for this disconformity to some degree; however, the presence of discrete areas of ashy deposit and the frequency of burned fiber clumps in Row 10 point strongly to functional use dissimilar to that of Rows 8 and 9.

\section{Comments}

In summary, it seems clear that native plant parts, leaves, stems, and grasses, primarily of lechuguilla (Agave lecheguilla), sotol (Dasylirion texana and D. wheeleri), and prickly pear (opuntia lindheimeri and 0 . phaeacantha), were employed to form a living and/or sleeping surface atop a deposit of limestone dust, and to line or otherwise support stone hearths or cooking pits. Deeper penetration into a less compacted section of the shelter might clarify our understanding, but the compaction itself is information regarding intensity and frequency of use, and will inevitably confuse and confound the excavator.

Artifacts occurred in every zone, but increased in number and variety in fiber deposits (Fig. 3). Faunal remains were recovered from all zones throughout the excavated area. Harold G. Wooldridge (1978) reports that the highest concentration of bone in Operation 3 occurred in Zones 5 (71 fragments) and 7 (106 fragments), with the largest number of species (15) being represented in Zone 5. Fish, rabbits, and rodents were most numerous, with deer elements identified in al1 but Zone 7 . The presence of 1 ithic, hide, bone, and fiber artifacts in the predominantly dust areas of Zones 3,5, and 7 may indicate that a minimum expanse of fiber flooring was placed, and discarded items were tossed aside off the living area. In addition, the frequency of 1ithic debitage in the dust areas of these zones suggests that the knapper moved away from a living area for tool preparation. However, it is possible that some of the debris, particularly lithic and bone fragments, sifted down from the fiber above.

There is a pronounced increase in the presence of quids in association with fiber areas, supporting the theory that food preparation and consumption took place on fiber-floored surfaces. In reporting on materials recovered from Parida Cave (also in Val Verde County), Alexander (1970:58) stated that Agave lecheguilla was apparently "a basic staple of the diet for at least the latest Parida inhabitants. . . species of Agave are well documented throughout much of the Southwest and northern Mexico both as principal sources of fiber and as prime food sources." From Parida Cave, as we11 as from Baker Cave, many quids appear as masticated bundles, and others as sections of the plant base, "the unchewed ends of which often appear scorched or slightly charred as though from roasting" (Alexander 1970:59).

The depth of excavation in Operation 3 corresponds to all of Word's Zone $V$ and a portion of his Zone IV. The presence of the diagnostic profectile point types of Ensor II and Langtry II in the lower levels of Operation 3 is consistent with his artifact assemblage from that depth. In a correlation of indicator projectile points and radiocarbon dates from rockshelters in central and southwest Texas, Weir (1976:64) places the Langtry type within a temporal span of 2130 B.C. to 1100 B.C., a Middle Archaic period dominated by the Pedernales point. Word 
(Word and Douglas 1970:99) finds the Langtry II variation prominent in Period 4 of his six-period sequence, dating from 2500 B.C. to 1000 B.C. Weir's correlation chart places the first appearance of Ensor points at 20 B.C. to A.D. 40, late in the San Marcos phase. Ensor II, as defined by Word (Word and Douglas 1970:100), occurs in his Period 5 between 1000 B.C. and A.D. 1000. A tentative time period of A.D. 1000 to A.D. 1600 is suggested by Word (ibid.) for the surface, and the recovery of a Perdiz arrow point in Zone 3 of Operation 3 is not inconsistent with this estimate. Because the Langtry $V$ (Word and Douglas 1970:29) point was found on the surface at the edge of one of Word's trenches, it cannot be considered in situ.

\section{Operation 4}

An experimental "lift-out" technique was tested in a $50 \mathrm{~cm} \times 50 \mathrm{~cm}$ square unit east of Operation 2 Unit N2/E3, in a section previously unexcavated. Eight discrete zones of alternating fiber and limestone dust layers were found to 1 ie between the surface and the bench left by Greer, adjacent to this test. Fiber layers were removed intact by quadrants and packed into shallow containers in the hope of transporting them to the laboratory undisturbed. The "floors" were then reassembled and the deposits examined for information regarding their composition. A preliminary analysis of this experiment has been made by Harvey Smith, Jr. (1977), in which he describes the strata of dust and fiber as varying in depth from $1 \mathrm{~cm}$ to $19 \mathrm{~cm}$ in an irregular pattern. He sees, for this period following 2500 B.C., a variable, intermittent occupation at Baker Cave. The section chosen for this very limited operation proved to contain a large concentration of quids, which formed $30 \%$ of the total fibrous content. The quids were of cut and chewed lechuguilla and sotol, the leaves of which were cooked a very dark brown. He found that a definite preference was shown for the "heart" of the plants and noted that the leaves showed sharp, clean cuts, presumably by flint knives. Woven and knotted fiber artifacts appeared to be primarily of sotol leaves. Analys is of plant and animal remains for Operation 4 is in process.

\section{Extent of Sampling}

Because of the fragmentary nature of some units in Operation 2, an average depth has been estimated in those units included in the expanding suboperation designated N2/E2. Only portions of four of those five units had been untouched by prior excavations (Fig. 8), but considerable material had sloughed off into what had been Word's trench to bedrock. This material was recovered as part of the 1976 work and is included in that sample. Unit N4/E3 had been considerably reduced, and it is estimated that about one-half of that square was taken in the 1976 sample.

Although a full $9-\mathrm{m}^{2}$ surface was examined in Operation 3 , the angle of slope was so distinct that the excavated area was triangular in cross section, and is represented as such in calculation of the sample taken.

On this basis, an estimate of the extent of sampling by the 1976 excavations is presented in Table 4. For a calculation of total sampling of Baker Cave to date, see Table 5. Work in progress of the 1976 excavations of Operation 2 and Operation 3 is shown in Figure $21, a, b$. 
TABLE 4. CALCULATION OF 1976 SAMPLE, BAKER CAVE

\section{OPERATION 2}

N2/E2 to bedrock

$1 \mathrm{~m} \times 2 \mathrm{~m}$ section (N2/E2, N2/E1) to depth of $2 \mathrm{~m}=4.00 \mathrm{~m}^{3}$

$1 \mathrm{~m} \times 1 \mathrm{~m}$ section (N2/EO, N3/E1) $=1.00 \mathrm{~m}^{3} \quad 5.00 \mathrm{~m}^{3}$

N3/E2 to Leve1 8

$1 \mathrm{~m} \times 1.5 \mathrm{~m}$ to depth of $1.40 \mathrm{~m} \quad 2.00 \mathrm{~m}^{3}$

N3/E3 to Level 7

$1 \mathrm{~m} \times 1 \mathrm{~m}$ to depth of $1.50 \mathrm{~m} \quad 1.50 \mathrm{~m}^{3}$

N4/E3 to Level 7

$.60 \mathrm{~m} \times .70 \mathrm{~m}=\frac{.42}{2} \mathrm{~m}=.21 \mathrm{~m}$ to depth of $.75 \mathrm{~m} \frac{.76 \mathrm{~m}^{3}}{3.66 \mathrm{~m}^{3}}$

OPERATION 3

$3 \mathrm{~m} \times 3 \mathrm{~m}=9 \mathrm{~m}^{2}$ to depth of $.74 \mathrm{~m}=\underline{6.66} \mathrm{~m}^{3} \quad 3.33 \mathrm{~m}^{3}$

OPERATION 4

$.50 \mathrm{~m} \times .50 \mathrm{~m}=.25 \mathrm{~m}^{2}$ to depth of $.41 \mathrm{~m}=$

$.11 \mathrm{~m}^{3}$

Total sample in 1976

$12.10 \mathrm{~m}^{3}$ 
TABLE 5. AREA AND VOLUME OF BAKER CAVE SAMPLE TO DATE

\section{AREA SAMPLED}

$\begin{array}{ll}\text { Total Area } \quad 451.50 \mathrm{~m}^{2} & 100.00 \%\end{array}$

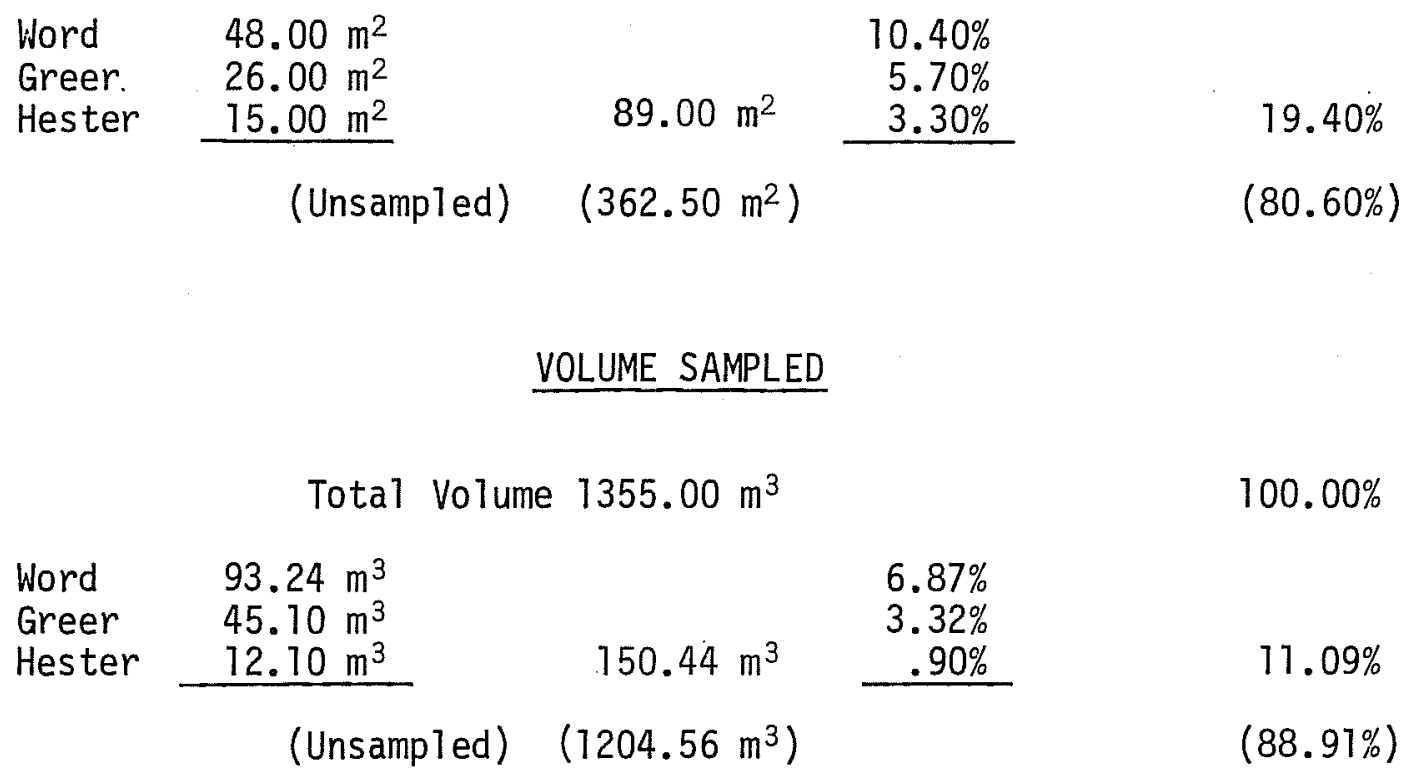




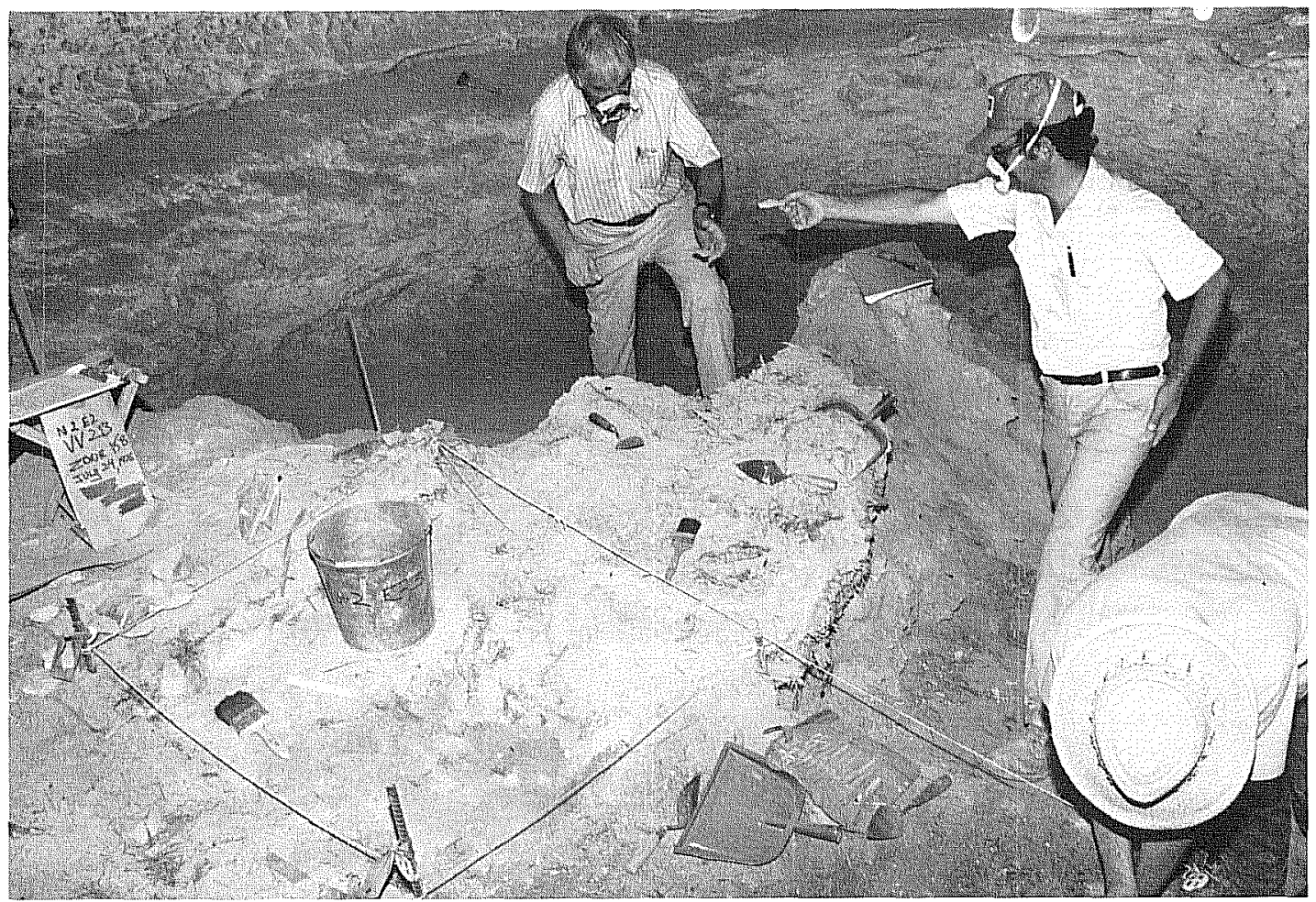

a

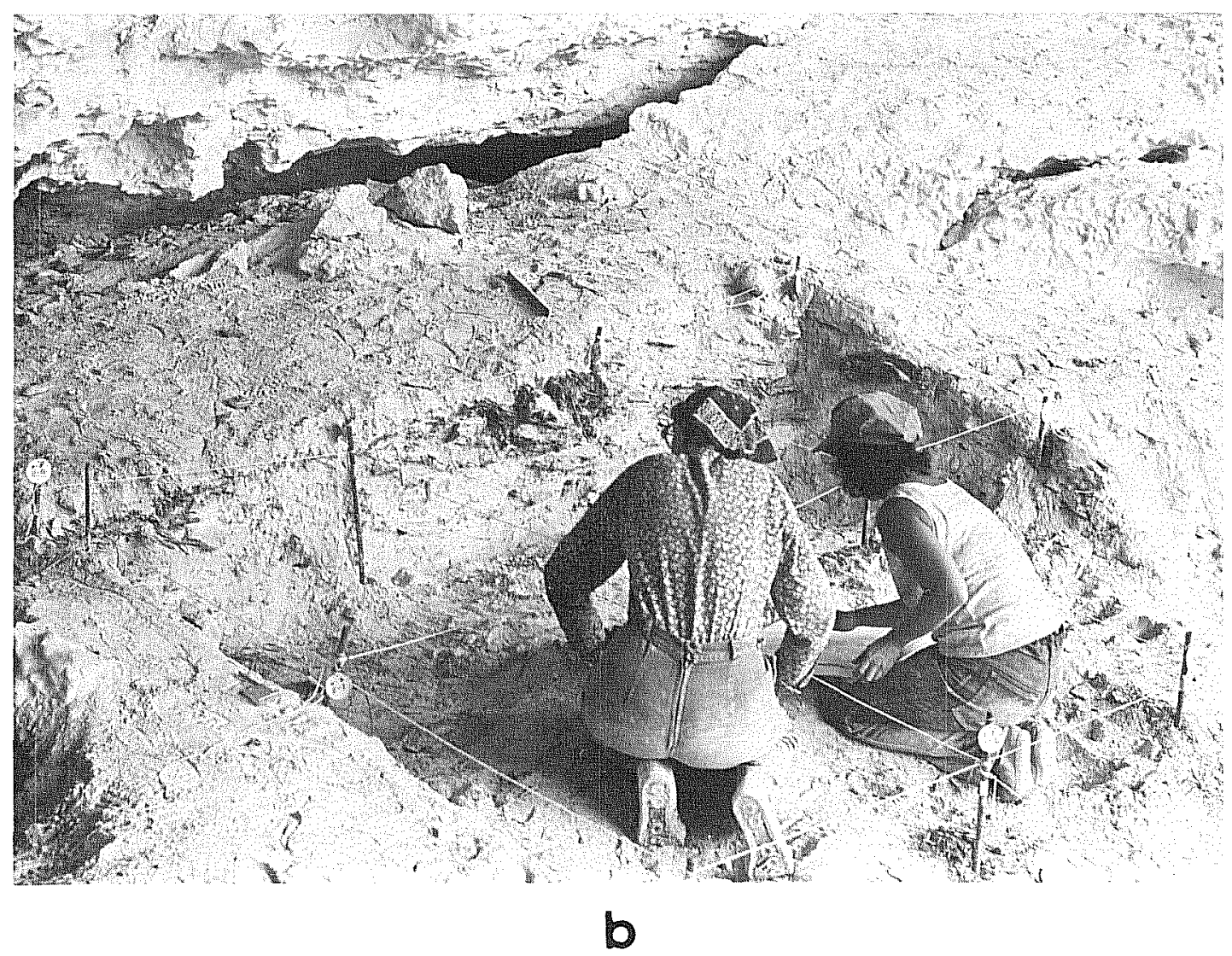

Figure 21. Work in Progress at Baker Cave, 1976. a, Operation 2; b, Operation 3 . 


\section{DESCRIPTION OF THE ARTIFACTS}

Artifacts are grouped on the basis of the raw material used in their manufacture. Under each group heading, the artifacts from Operation 2 and Operation 3 are described separately.

\section{Lithic Artifacts}

Only implements are described in detail. Lithic debitage in the form of flakes and flake fragments totalled more than 17,000 specimens: 16,904 from Operation 2 and 244 from Operation 3. These items are not described but are included in the tabulations of frequency and distribution of artifacts presented in Table 2 and Table 3.

Projectile Points (52 specimens)

Included in this category are fragments and preforms as well as complete points. Unless otherwise noted, typology follows that set forth by Suhm and Jelks (1962).

OPERATION 2 (48 specimens)

Baker I (one specimen; Fig. 22,a)

Description: Distal half and one side missing. Bifurcated, expanding stem, prominent corner-notched barb. Length (estimated), $6.5 \mathrm{~cm}$; width at barbs (estimated), $3.2 \mathrm{~cm}$; thickness, $0.5 \mathrm{~cm}$; depth of basal notch, $0.8 \mathrm{~cm}$. Tentative typology was proposed by Word (Word and Douglas 1970:2); included with Early Corner-Notched points by Hester (1971:11); described as "Bifurcated Stem" in Time Period II proposed by Story (Story and Bryant 1966:11).

Provenience: Zones 17-23, Leve1 1, N2/E2.

Bandy (one specimen; Fig. 22,b)

Description: Distal portion and one side missing. Fragment has straight blade, deep corner notch with long barb, expanding stem with shallow basal notch. Length (estimated), $6.5 \mathrm{~cm}$; width at barbs (estimated), $3.5 \mathrm{~cm}$; width at base, $1.6 \mathrm{~cm}$; depth of basal notch, $0.3 \mathrm{~cm}$; thickness, $0.4 \mathrm{~cm}$. Tentative typology was proposed by Word (Word and Doublas 1970:2); included with Early CornerNotched points by Hester (1971:11).

Provenience: Zones 17-23, Level 3, N2/E2.

Early Triangular (13 specimens; Fig. 22,d,e)

Description: Triangular forms varying from isosceles to equilateral. Bases concave to straight. Slight to pronounced basal thinning. Four specimens have 


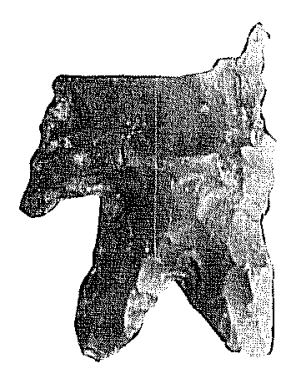

a

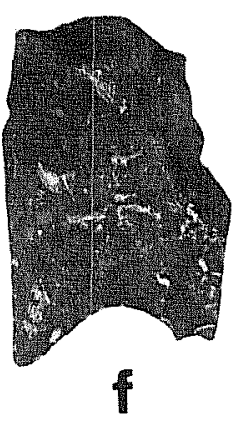

f

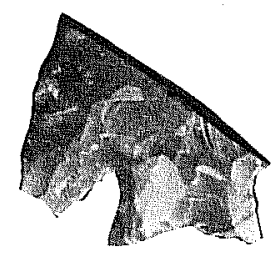

b
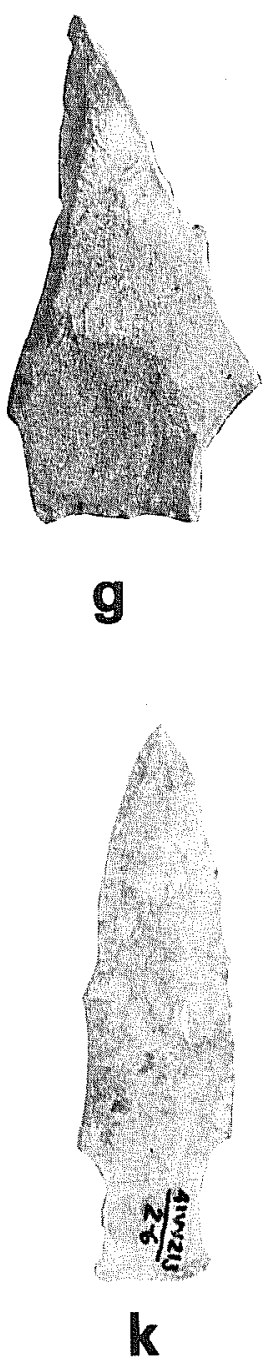

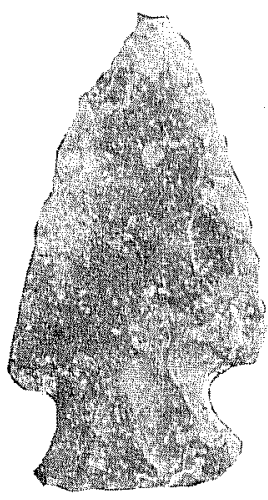

C

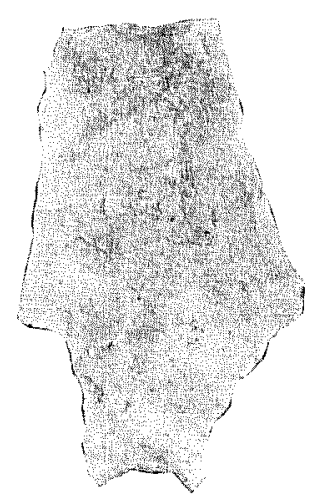

h

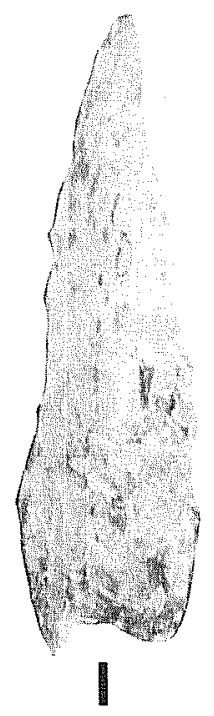

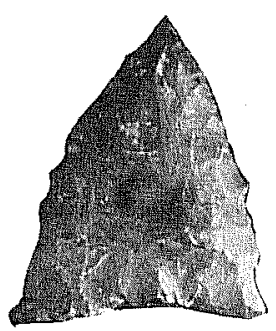

d
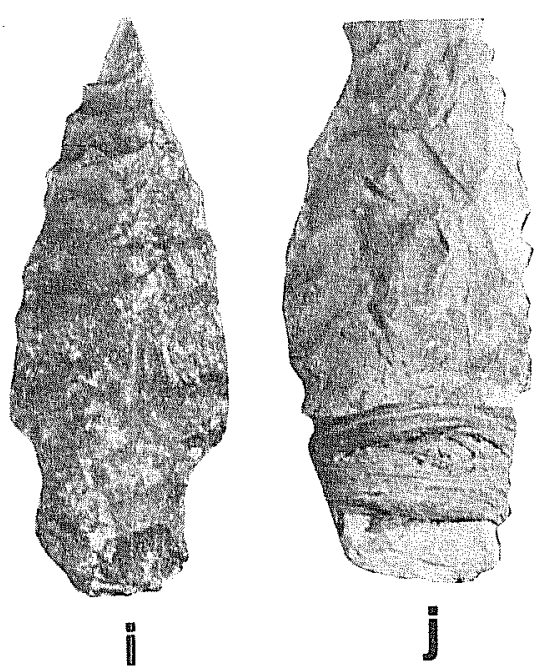

Figure 22. Projectile Points. a, Baker I; b, Bandy; c, Corner-Notched; $d, e$, Early Triangular; $f$, Golondrina; g, Langtry I; $h$, Langtry II; i,j, Pandale; k, Stemmed; 1, Unstemmed Type I; m, Unstemmed Type III (probably reworked Golondrina). Artifacts are shown actual size (photographs by Vicki Holloway). 
residue of hafting mastic on base. Seven specimens are complete; five specimens are proximal fragments; one specimen is reworked on the distal end. Length, $2.5 \mathrm{~cm}$ to $4.5 \mathrm{~cm}$; width at base, $2.5 \mathrm{~cm}$ to $4 \mathrm{~cm}$; thickness, $0.4 \mathrm{~cm}$ to $0.6 \mathrm{~cm}$. Classification after Hester (1971:11).

Provenience: Zone 13, N2/E2 (one); Zone 14, N3/E3 (one); Zone 15b, N2/E2 (one), N2/E3 (one); Zone 16b, N2/E2 (four), no provenience (one); Zones 17-23, Leve1 1, N2/E2 (one), Leve1 2, N2/E2 (one), Level 5, N2/E2 (one), Leve1 6, N2/E2 (one).

Golondrina (one specimen; Fig. 22,f)

Description: The point is lacking the distal half and shows crude reworking of distal break. Lanceolate form evident, blades contracting at base to form slightly flaring basal corners. Tip of basal corner broken. Dulling on base and on distal sides to length of $2.4 \mathrm{~cm}$. Made of gray brown, fine-grained chert with thin coating of reddish dust adhering to surface. Length (estimated), $7.5 \mathrm{~cm}$; length of fragment, $3.5 \mathrm{~cm}$; width, $2.3 \mathrm{~cm}$; thickness, $0.6 \mathrm{~cm}$; depth of basal concavity, $0.6 \mathrm{~cm}$. Typology after Johnson (1964) and Kelly (1976).

Provenience: Zones 17-23, Leve1 7, N2/E2.

Langtry I (one specimen; Fig. 22,g)

Description: Reworked on one side where lateral break had removed shoulder. Original edge trimming struck or broken from opposite side. Wide, slightly concave base, flaring to pointed shoulder. Length, $5.5 \mathrm{~cm}$; width at base, $1.6 \mathrm{~cm}$; width at shoulder (estimated), $3 \mathrm{~cm}$; thickness, $0.5 \mathrm{~cm}$. Placement within Langtry series follows Word (Word and Douglas 1970:28).

Provenience: Zones 12, 13, 14 (mixed lot), N3/E3.

Langtry II (one specimen; Fig. 22,h)

Description: Straight blades, contracting stem, concave base. Distal end missing. Length (estimated), $8 \mathrm{~cm}$; width at shoulders, $3 \mathrm{~cm}$; width at base, $1 \mathrm{~cm}$; thickness, $0.7 \mathrm{~cm}$. Placement within Langtry series follows Word (Word and Douglas $1970: 28)$.

Provenience: Zones 12, 13, 14 (mixed 1ot) N3/E3.

Pandale (12 specimens; Figs. $22, i, j ; 23, b, c)$

Description: Long, slender, convex blades narrowing to concave above slightly flaring base. Base straight to convex. Shoulders weak to pronounced. Entire length of both sides is bifacially flaked from centerline of blade to outer edge, to produce a clockwise curve on each edge. Bases trimmed in counterclockwise curve, resulting in a pronounced corkscrew twist when point is viewed in profile. Some recurving at tip to counterclockwise is observed on complete specimens. Hafting sinew in situ on one base. Three complete points, seven proximal 
fragments, two preforms. Points and fragments: length, $6 \mathrm{~cm}$ to $9 \mathrm{~cm}$; width at shoulders, $1.8 \mathrm{~cm}$ to $2.1 \mathrm{~cm}$; width at base, $1.5 \mathrm{~cm}$ to $2 \mathrm{~cm}$; thickness, $0.6 \mathrm{~cm}$ to $0.7 \mathrm{~cm}$. Preforms are bifacially trimmed on both edges into unfinished twisted form, bases incomplete. Hinge fracture on one face of each. Length, $6 \mathrm{~cm}$ to $7.3 \mathrm{~cm}$; width, $2.5 \mathrm{~cm}$ to $3.5 \mathrm{~cm}$; thickness, $1 \mathrm{~cm}$ to $1.8 \mathrm{~cm}$.

Provenience: Zones 12, 13, 14 (mixed lot), N3/E3 (two); Zone 13, N2/E2 (one preform); Zone 14, N3/E3 (six); Zone 15b, N2/E2 (one preform); Zone 16, N4/E3 (one); Zone 17-23, Leve1 1, N2/E2 (one).

\section{Miscellaneous Points (18 specimens)}

Corner-Notched (one specimen; Fib. 22,c)

Description: Triangular blade, convex edges. We11-defined, round corner notches. Expanding stem, slightly concave base. Length, $5 \mathrm{~cm}$; width at shoulders, $2.7 \mathrm{~cm}$; width at base, $2.2 \mathrm{~cm}$; thickness, $0.6 \mathrm{~cm}$.

Provenience: Zone 16, N2/E3.

Triangular Type I (one specimen)

Description: Blades slightly convex, no visible shoulders. Base missing. Length, $5.2 \mathrm{~cm}$; width, $2.3 \mathrm{~cm}$; thickness, $0.8 \mathrm{~cm}$.

Provenience: No provenience (clean-up from Zones 17-23).

Triangular Type II (one specimen)

Description: Straight blades, straight base. Tip missing. Length (estimated), $4.5 \mathrm{~cm}$; width, $2.1 \mathrm{~cm}$; thickness, $0.5 \mathrm{~cm}$.

Provenience: No provenience (co1lapse of N2/E2 in Zones 15-23).

Stemmed (12 specimens; Fig. 22,k)

Description: Lanceolate forms, convex blades. Side-notched, slightly expanded stems. Bases convex to concave. Six complete, six proximal fragments. Length, $4.7 \mathrm{~cm}$ to $5.7 \mathrm{~cm}$; width at shoulders, $1.5 \mathrm{~cm}$ to $2 \mathrm{~cm}$; width at base, $1.1 \mathrm{~cm}$ to $1.5 \mathrm{~cm}$; thickness, $0.5 \mathrm{~cm}$ to $0.7 \mathrm{~cm}$.

Provenience: Zone 14, N2/E2 (two); Zone 15, N2/E2 (one), N2/E3 (one); Zone 15b, N2/E3 (two); Zone 16, N2/E3 (one); Zone 16b, N3/E3 (one); Zones 17-23, Level 2, N2/E2 (one); Level 3, N2/E2 (one); Leve1 6, N2/E2 (one).

Unstemmed Type I (one specimen; Fig. 22,1)

Description: Curved leaf form, convex blades widest in proximal one-fourth, contracting to base. Base thinned, central notch. Length, $6.5 \mathrm{~cm}$; width, $2 \mathrm{~cm}$; thickness, $0.8 \mathrm{~cm}$. 
Provenience: Zone 18, N2/E3.

Unstemmed Type II (one specimen)

Description: Lanceolate form, blades convex, contracting at proximal end. Base thinned, slightly convex, distal portion missing. Fire spalled. Length (estimated), $8.5 \mathrm{~cm}$; width, $3.1 \mathrm{~cm}$; thickness, $0.8 \mathrm{~cm}$.

Provenience: Zone 14, N2/E3.

Unstemmed Type III (one specimen; Fig. 22,m)

Description: Base of lanceolate form. Blades straight, basal notch with small thinning flakes and flaring corners. Possibly a reworked Golondrina point.

Length, $1.5 \mathrm{~cm}$; width at base, $2.6 \mathrm{~cm}$; thickness, $0.6 \mathrm{~cm}$; depth of basal notch, $0.3 \mathrm{~cm}$.

Provenience: Zones 17-23, Leve1 5, N2/E2.

OPERATION 3 (four specimens)

Ensor II (one specimen)

Description: Distał end missing. Elongated, straight blades, prominent side notches. Base generally straight with slightly concave portions defining stem corners. Length (estimated), $6.5 \mathrm{~cm}$; width at base, $2.3 \mathrm{~cm}$; thickness, $0.8 \mathrm{~cm}$. Placement within Ensor series follows Word (Word and Douglas 1970:26).

Provenience: Zone 7, N9/E2.

Langtry II (one specimen)

Description: Fragment represents base, stem, and part of one shoulder. Distal portion apparently broken off in manufacture. Straight-sided, contracting stem, concave base. Length (estimated), $8 \mathrm{~cm}$. Placement within Langtry series follows Word (Word and Douglas 1970:28).

Provenience: Zone 7, N9/El.

Langtry $V$ (one specimen)

Description: Blade edges concave. Stem straight, flaring to pointed shoulders. Base straight. Distal tip missing. Length (estimated), $6.3 \mathrm{~cm}$; width at shoulders, $2.5 \mathrm{~cm}$; thickness, $0.5 \mathrm{~cm}$. Placement within Langtry series follows Word (Word and Douglas 1970:29).

Provenience: Zone 1 (surface), N8/E1. 
Perdiz (one specimen)

Description: Distal tip missing, impact fracture indicated. Portion of stem base missing. Serrated blade edges, finely made. Length (estimated), $3.2 \mathrm{~cm}$; width at barbs, $1.7 \mathrm{~cm}$; thickness, $0.19 \mathrm{~cm}$.

Provenience: Zone 3, N9/ET.

Bifaces (six specimens)

The term "biface" describes a bifacially flaked tool of uncertain function. Some may have served as knives; others are probably preforms or manufacturing failures.

OPERATION 2 (five specimens)

Leaf Shaped (four specimens; Fig. $23, a, a^{\prime}, d, h$ )

Description: Leaf-shaped outline established, hinge fractured during thinning process. One specimen of general conformation and size of Golondrina type, made on secondary flake or blade of black chert with central ridge of cortex remaining on dorsal side. Some evidence of heating, with areas of fire spalling on this specimen. Length, $7.8 \mathrm{~cm}$ to $10.4 \mathrm{~cm}$; width $2.7 \mathrm{~cm}$ to $5 \mathrm{~cm}$; thickness $1.35 \mathrm{~cm}$ to $2.4 \mathrm{~cm}$.

Provenience: Zones 17-23, Leve1 5, N2/E2 (one); Leve1 7, N2/E2 (one); No provenience (two).

Lozenge Shaped (one specimen)

Description: Lozenge form with dorsal ridge established. Cavity with quartz crystal exposed in material. Cortex remaining on one ventral end. Burned. Length, $8.7 \mathrm{~cm}$; width, $3.6 \mathrm{~cm}$; thickness, $3.3 \mathrm{~cm}$.

Provenience: Zone 15, N4/E3.

OPERATION 3 (two specimens)

Triangular (one specimen)

Description: Roughly triangular in form. Bifacially worked on two sides. Made on a flake. Length, $4.5 \mathrm{~cm}$; width, at base, $3.8 \mathrm{~cm}$; thickness, $0.6 \mathrm{~cm}$.

Provenience: Zone 7, N9/E2.

Subtriangular (one specimen)

Description: Ovate with distal end forming rounded point. Bifacially worked on all edges except convex base. Made on a flake. Length, $5.5 \mathrm{~cm}$; width, $4.1 \mathrm{~cm}$; thickness, $0.7 \mathrm{~cm}$.

Provenience: Zone 8, N8/E2. 


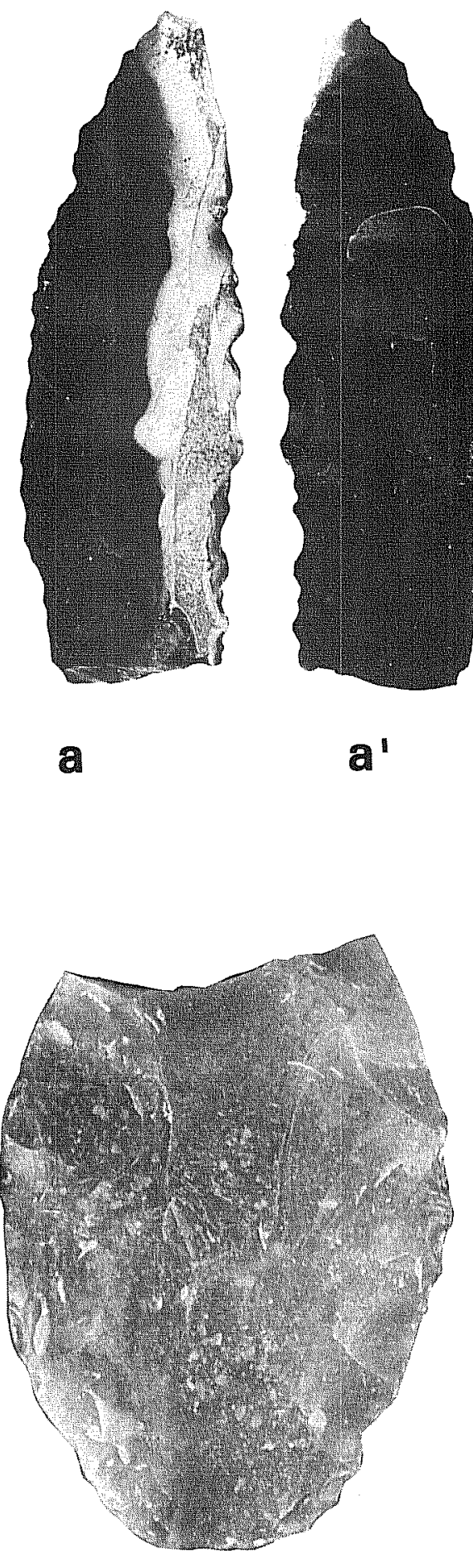

e
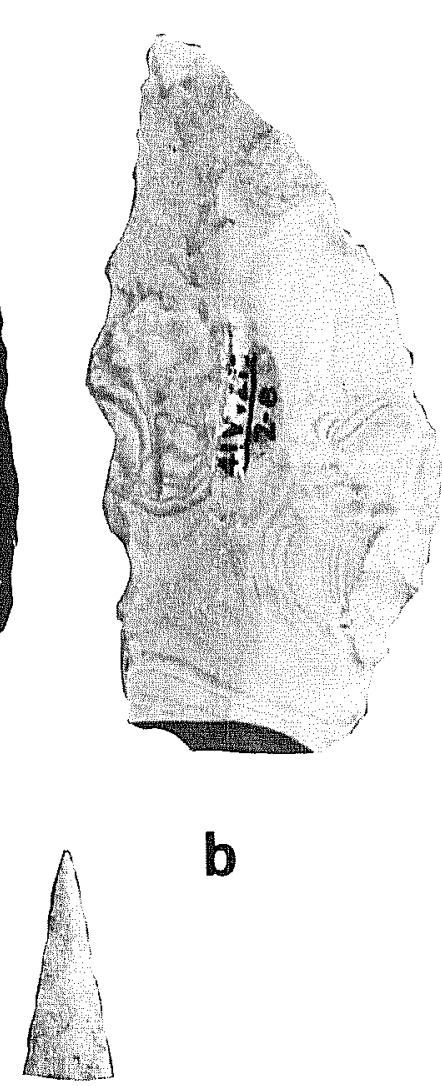

b
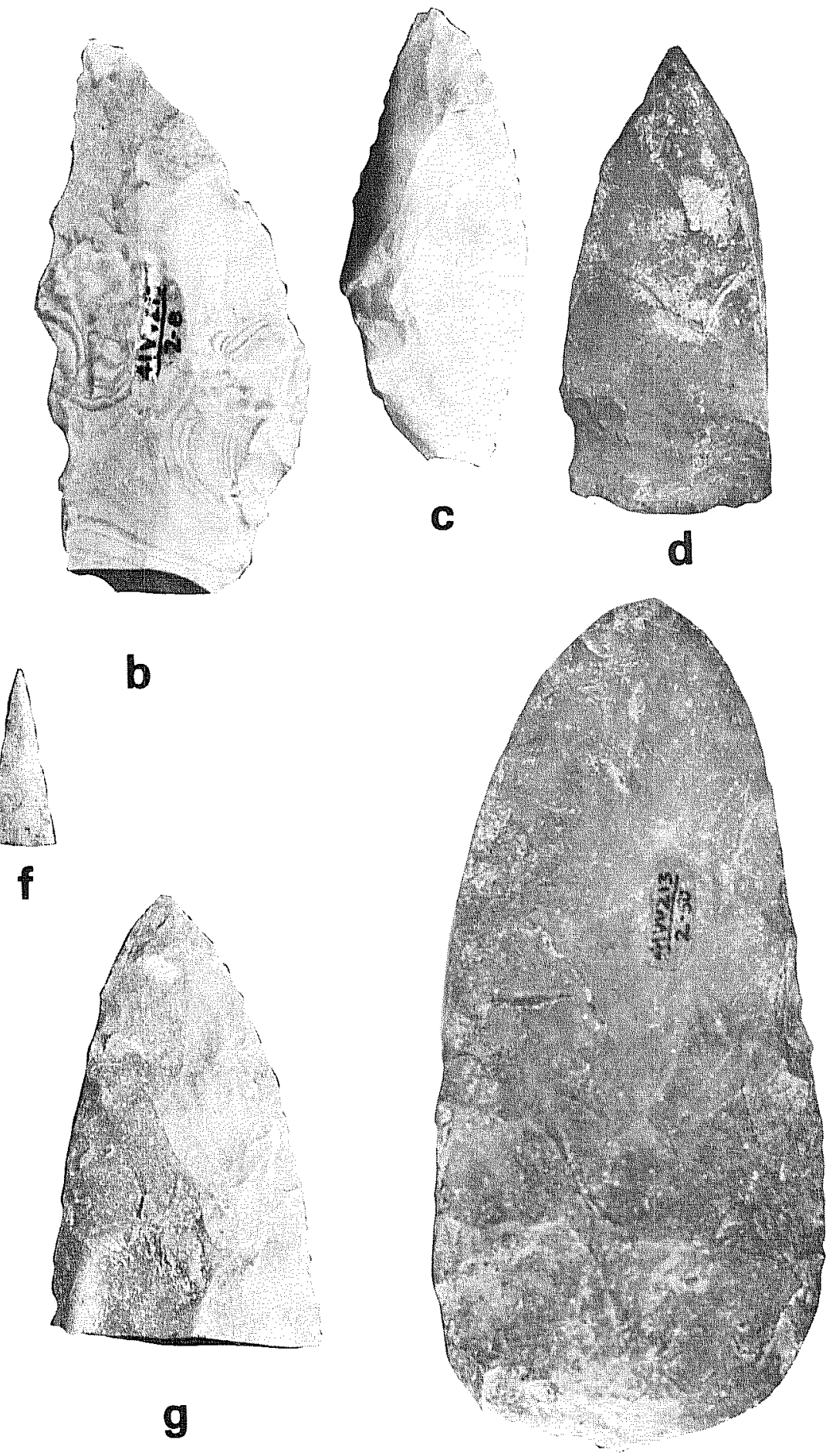

h

Figure 23. Preforms, Bifaces, and Fragments. a, a',d,h, leaf-shaped preforms, possibly Golondrina; b,c, twisted preforms, probably Pandale; e, Oval Type II fragment; f, Distal Type I fragment; g, Distal Type II fragment. Artifacts are shown actual size (photographs by Vicki Holloway). 
Biface Fragments (85 specimens)

OPERATION 2 (81 specimens)

Distal Type I (19 specimens; Fig. 23,f)

Description: Sma11, thin, acute angle tips. Length, $0.6 \mathrm{~cm}$ to $2.3 \mathrm{~cm}$; width, $1 \mathrm{~cm}$ to $1.6 \mathrm{~cm}$; thickness, $0.6 \mathrm{~cm}$ to $0.5 \mathrm{~cm}$.

Provenience: Zone 14, N2/E2 (one), N2/E3 (one), N3/E3 (one); Zones 12, 13, 14 (mixed lot), N3/E3 (one); Zones 14, 15 (Pandale pit), N2/E3 (one); Zone 15, N2/E2 (one); Zone 15b, N2/E2 (two); Zones 15, 15b (mixed 1ot), N3/E3 (one); Zone 16, N2/E3 (one); Zone 16b, N2/E2 (one), N3/E3 (one); Zones 17-23, Level 5, N2/E2 (one), Level 6, N2/E2 (six).

Distal Type II (28 specimens; Fig. 23,g)

Description: Medium to large, acute to right angle tips. Length, $3 \mathrm{~cm}$ to $6.3 \mathrm{~cm}$; width, $3 \mathrm{~cm}$ to $6.3 \mathrm{~cm}$; thickness, $0.3 \mathrm{~cm}$ to $1.6 \mathrm{~cm}$.

Provenience: Zone 14, N2/E3 (one), N3/E3 (one), N4/E3 (two); Zones 12, 13, 14 (mixed 1ot), N3/E3 (one); Zone 15, N4/E3 (one); Zone 15b, N3/E3 (one); Zones 15, 15b (mixed lot), N3/E3 (one); Zones 17-23, Leve1 1, N2/E2 (one), Leve1 3, N2/E2 (two), Leve1 5, N2/E2 (two), Leve1 6, N2/E2 (two); No provenience $(10)$.

Medial (five specimens)

Description: Both distal and proximal sections broken off. Length, $0.4 \mathrm{~cm}$ to $8.5 \mathrm{~cm}$; width, $2.3 \mathrm{~cm}$ to $8.5 \mathrm{~cm}$; thickness, $0.5 \mathrm{~cm}$ to $2.4 \mathrm{~cm}$.

Provenience: Zone 13, N4/E3 (one); Zone 14, N2/E3 (one); Zone 15b, N2/E3 (one); No provenience (one); Zones 17-23, Leve1 4, N2/E2 (one).

Proximal (six specimens)

Description: Basal fragments. Length, $1.8 \mathrm{~cm}$ to $8 \mathrm{~cm}$; width, $2.9 \mathrm{~cm}$ to $4.5 \mathrm{~cm}$; thickness, $0.7 \mathrm{~cm}$ to $1 \mathrm{~cm}$.

Provenience: Zone 14, N2/E3 (one); Zone 15, N2/E2 (one); Zones 17-23, Leve1 5, N2/E2 (one); No provenience (three).

Lateral (17 specimens)

Description: Fragment of biface with one side missing. Fragments bifacially flaked on one edge or two adjoining edges, not identifiable as distal or proximal portion. Eight burned. Length, $2.1 \mathrm{~cm}$ to $6.2 \mathrm{~cm}$; width, $1.2 \mathrm{~cm}$ to $4.7 \mathrm{~cm}$; thickness, $0.4 \mathrm{~cm}$ to $1.4 \mathrm{~cm}$. 
Provenience: Zone 14, N2/E3 (three), N3/E3 (one), N4/E3 (one); Zones 12, 13, 14 (mixed 1ot), N3/E3 (four); Zones 14,15 (Pandale pit), N2/E3 (one); Zone 15, N4/E3 (one); Zone 15b, N2/E2 (one); Zones 15, 15b (mixed 1ot), N3/E3 (one); Zone 16b, N3/E3 (three); No provenience, N2/E2 (one).

Oval Type I (one specimen)

Description: Fragment of small, thin, bifacially flaked oval or round tool. Diameter, $2.2 \mathrm{~cm}$; length from break to edge, $0.7 \mathrm{~cm}$; thickness, $0.4 \mathrm{~cm}$.

Provenience: Zones 17-23, Leve1 5, N2/E2.

Oval Type II (five specimens; Fig. 23,e)

Description: Medium to large fragments of oval or round bifaces. Diameter, $3.9 \mathrm{~cm}$ to $5.5 \mathrm{~cm}$; length from break to edge, $2.7 \mathrm{~cm}$ to $7.1 \mathrm{~cm}$; thickness, $0.8 \mathrm{~cm}$ to $1.5 \mathrm{~cm}$.

Provenience: Zones 17-23, Leve1 1, N2/E2 (one), Leve1 3, N2/E2 (two); No provenience, N2/E2 (two).

OPERATION 3 (four specimens)

Medial (three specimens)

Description: Bifacially worked on two edges. Probably broken in manufacture. Length, $2.3 \mathrm{~cm}$ to $5 \mathrm{~cm}$; width, $4.5 \mathrm{~cm}$ to $6.2 \mathrm{~cm}$; thickness, $0.5 \mathrm{~cm}$ to $2.2 \mathrm{~cm}$.

Provenience: Zone 2, N9/E2 (one); Zone 3, N9/El (one); Zone 6, N9/E2 (one).

Lateral (one specimen)

Description: Triangular fragment bifacially trimmed on one side, broken on other two. Length (trimmed side), $3.7 \mathrm{~cm}$; thickness, $0.6 \mathrm{~cm}$.

Provenience: Zone 5, N10/El.

Burins (eight specimens)

The burin has been described at length by Epstein $(1960,1963)$. In this report the term "burin" describes a piece of chert which bears a sma11, beaklike projection intentionally prepared along one edge. The prime criterion used in this analysis is the deliberate formation of one side of the beak by removal of one or more long, narrow flakes from the edge (rather than the face). Burin blows result in scars which "are generally characterized by a small concavity (negative bulb of percussion) at the point of impact, and sometimes by hinge fractures at the 
opposite end of the scar" (Johnson 1964:67). The beak may be developed on the opposite side by similar removal of long-axis spal1s, by conventional edge flaking, by retouching a broken, pointed tool, or by utilization of a fortuitous shape of the raw material. A burin beak normally shows dulling or polish from use and is believed to have been useful as a grooving implement or as a sturdy form of graver. Organic residue adhering to some of the burins recovered from Baker Cave indicates use at some stage of food or plant processing.

\section{OPERATION 2 (eight specimens)}

Description: All formed on interior flake fragments. Length, $2.2 \mathrm{~cm}$ to $7.5 \mathrm{~cm}$; width, $0.5 \mathrm{~cm}$ to $7 \mathrm{~cm}$; thickness, $0.2 \mathrm{~cm}$ to $1.5 \mathrm{~cm}$.

Provenience: Zone 14, N3/E3 (one), N4/E3 (one); Zones 12, 13, 14 (mixed 1ot), N3/E3 (one); Zone 15b, N2/E3 (one); Zones 15, 15b, N3/E3 (one); Zones 17-23, Level 2, N2/E2 (one), Level 8, N2/E3 (one); ilo provenience (one).

Clear Fork Tools (one specimen; Fig. 24, $a, a^{\prime}$ )

The clear Fork tool is a triangular, flaked implement of chert with a steep bit prepared at the distal, broad end. The dorsal face is fashioned with a welldefined central ridge, and the tool is plano-convex in cross section. It may be bifacially or unifacially trimmed. These tools were apparently hafted and may have served as adzes or in a planing or fleshing capacity. Similar tools were described as Clear Fork gouges by Ray (1941). Epstein (1969) reports their recovery from the San Isidro site in northern Mexico in inconclusive association with Plainview golondrina points. Their possible functions have been discussed by Hester, Gilbow, and Albee (1973).

Description: This specimen made of light gray, fine-grained chert, both faces covered with reddish brown residue, occurring as heavy spotting in some areas. Proximal end missing. The lighter colored bit has been resharpened and residue spotting occurred subsequently. The "fresh" appearance of the bit is duplicated at the proximal end break, and some attempt to thin this end after breakage is evident. Ventral surface of bit edge shows polish, and flake scars in that region are smoothed and slick; residue stains are heaviest in this area. Sides (lateral edges) show light to moderate dulling. Residue on this specimen, tentatively identified by Harry $J$. Shafer as organic (personal communication) indicates use in food or plant preparation. Length, $0.62 \mathrm{~cm}$; width, $0.45 \mathrm{~cm}$; thickness (maximum), $0.14 \mathrm{~cm}$; angle of sides, $46^{\circ}$ to $50^{\circ}$; angle of bit, $60^{\circ}$ to $61^{\circ}$.

\section{OPERATION 2 (one specimen)}

Provenience: Zones 17-23, Level 7, N3/E2.

\section{Scrapers (79 specimens)}

The term "scraper" is used in this paper to classify chert tools which exhibit intentional edge flaking or trimming to form a beveled, sometimes steep, working edge. The working edge is normally dulled and sometimes reduced by wear. This 

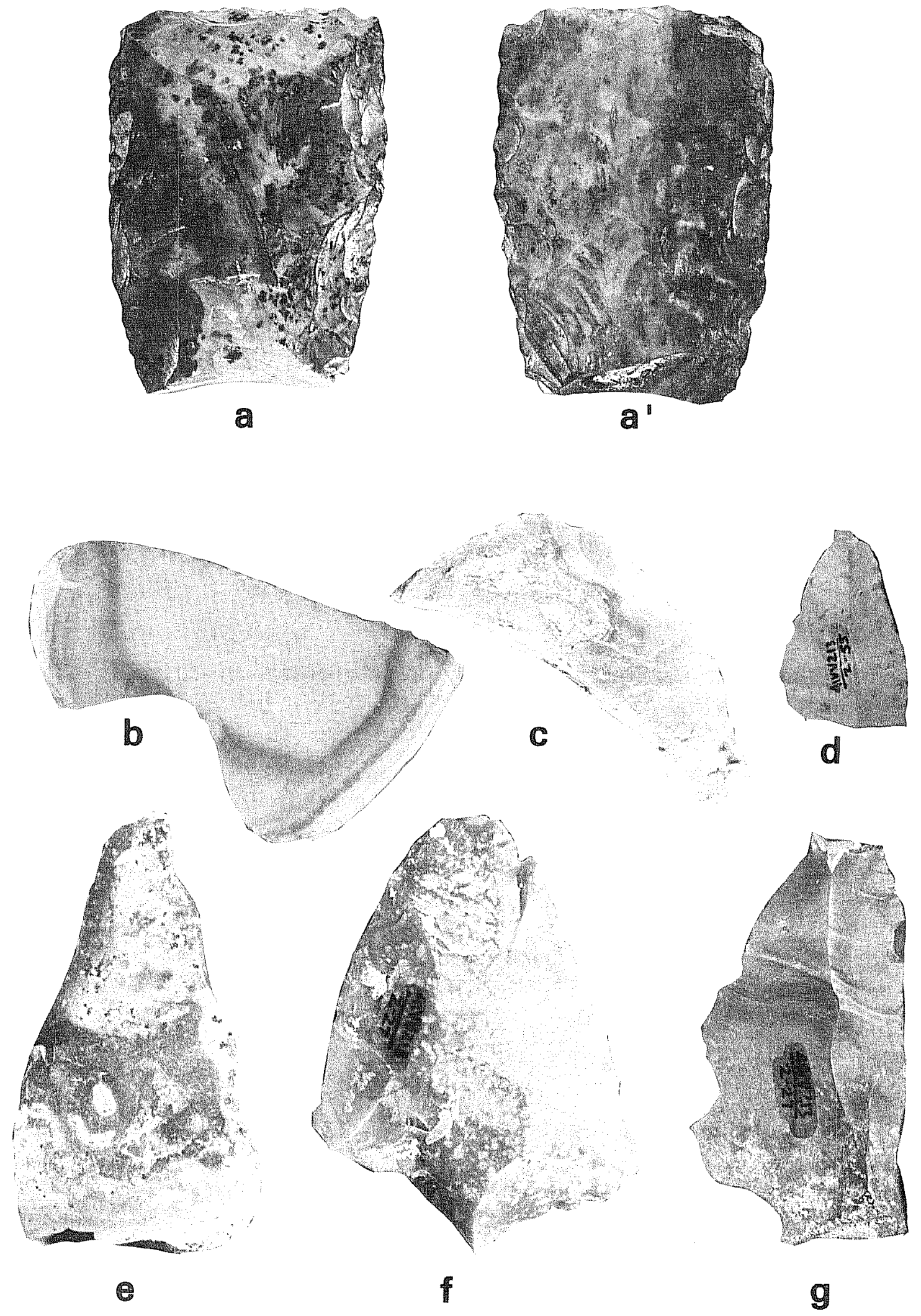

Figure 24. Clear Fork Tool and Scrapers. a, a', Clear Fork tool; b-d, Scrapers II; e, Scraper III; f, Scraper IV; g, Scraper V (spokeshave). Artifacts are shown actual size (photographs by Vicki Holloway). 
implement is most commonly produced on flakes but may be formed from remnant cores or biface fragments. On many of these tools, traces of organic residue and smoothing of the functional edge suggest use in plant processing, fleshing, or hide preparation. For purposes of description, five "types" have been established.

OPERATION 2 (74 specimens)

Type I (46 specimens)

Description: One working edge on end or side of specimen. Length, $1.3 \mathrm{~cm}$ to $9.2 \mathrm{~cm}$; width, $1 \mathrm{~cm}$ to $8.5 \mathrm{~cm}$; thickness, $0.2 \mathrm{~cm}$ to $2 \mathrm{~cm}$.

Provenience: Zone 12 (surface) (two); Zones 12, 13, 14 (mixed 1ot) (two); Zone 14, N2/E3 (one); Zone 14, N4/E3 (one); Zone 15, N2/E2 (one); N2/E3 (five); Zones 15, 15b (mixed 1ot), N3/E3 (two); Zone 16, N2/E3 (three); Zone 16b, N3/E3 (two); Zones 17-23, Leve1 1, N2/E2 (three), Level 2, N2/E3 (one), Level 3, N2/E2 (six), Leve1 4, N2/E2 (six), Leve1 5, N2/E2 (three), Leve1 6, N2/E2 (four), Level 7, N2/E2 (two), Level 8, No provenience (two).

Type II (10 specimens; Fig. 24,b-d)

Description: Two working edges. May be on opposite or adjacent sides or on two continuous sides of a crescent form. Length, $3.3 \mathrm{~cm}$ to $10 \mathrm{~cm}$; width, $1.7 \mathrm{~cm}$ to $10.4 \mathrm{~cm}$; thickness, $0.5 \mathrm{~cm}$ to $1.8 \mathrm{~cm}$.

Provenience: Zone 12 (surface) (one); Zone 14, N2/E3 (one); Zone 15b, N2/E3 (one); Zone 16, N2/E3 (one); Zones 17-23, Level 3, N2/E2 (one), Level 5, N2/E2 (one), Leve1 6, N3/E2 (one), Leve1 7, N2/E2 (one); No provenience (two).

Type III (five specimens; Fig. 24,e)

Description: Three working edges on oval or rectangular form. Length, $3.5 \mathrm{~cm}$ to $8.2 \mathrm{~cm}$; width, $3.2 \mathrm{~cm}$ to $7.5 \mathrm{~cm}$; thickness, $0.5 \mathrm{~cm}$ to $2.3 \mathrm{~cm}$.

Provenience: Zone 12 (surface) (one); Zone 15b, N2/E3 (two); Zones 17-23, Leve1 4, N2/E2 (one), Leve1 6, N2/E2 (one).

Type IV (two specimens; Fig. 24,f)

Description: All edges worked. Plano-convex form. Length about twice width, both ends tapering. Length, $7.5 \mathrm{~cm}$ to $9.3 \mathrm{~cm}$; width, $3.7 \mathrm{~cm}$ to $4.7 \mathrm{~cm}$; thickness, $0.6 \mathrm{~cm}$ to $1.2 \mathrm{~cm}$.

Provenience: Zones 17-23, No provenience (two).

Type U (11 specimens; Fig. 24,g)

Description: One or more concave notches on edge. May be intentionally prepared by flaking or may be reduced by wear on secondary use of flake scar on 
biface fragment. Concavity may be a pronounced notch on a shallow curve. Sometimes referred to as "spokeshaves" since they appear to have been used on rounded surfaces. Length, $3.3 \mathrm{~cm}$ to $6.7 \mathrm{~cm}$; width, $1.7 \mathrm{~cm}$ to $3.5 \mathrm{~cm}$; thickness, $0.6 \mathrm{~cm}$ to $1.8 \mathrm{~cm}$.

Provenience: Zone 14, N3/E3 (one); Zone 16, N2/E3 (one), N4/E3 (one); Zones 1723, Leve1 1, N2/E2 (one), Level 5, N2/E2 (two), Level 6, N2/E2 (one), Level 7, N2/E2; No provenience (one).

OPERATION 3 (five specimens)

Type I (three specimens)

Description: Trimmed working edge on one side of convex flake edge. Length, $4 \mathrm{~cm}$ to $5.7 \mathrm{~cm}$; width, $2.1 \mathrm{~cm}$ to $6.8 \mathrm{~cm}$; thickness, $4.0 \mathrm{~cm}$ to $1.1 \mathrm{~cm}$.

Provenience: Zone 1 (surface), No provenience (one); Zone 2, N10/E2 (one); Zone 4, N9/E2 (one).

Type II (one specimen)

Description: Flake fragment with serrated unifacial trimming on two sides to form a point. Length, $3.9 \mathrm{~cm}$; width, $1.9 \mathrm{~cm}$; thickness, $0.4 \mathrm{~cm}$.

Provenience: Zone 8, N8/E3.

Type III (one specimen)

Description: Subtriangular flake trimmed unifacially on three sides. Residue stains on ventral surface. Length, $6.9 \mathrm{~cm}$; width, $7.1 \mathrm{~cm}$; thickness, $1.6 \mathrm{~cm}$.

Provenience: Zone 8, N8/E3.

Trimmed Flakes (nine specimens)

This classification is used for chert flakes or fragments which exhibit intentional edge flaking for an undetermined purpose. They lack dulling or reduction of the flaked edges, indicative of use as a scraper.

OPERATION 2 (nine specimens)

Type I (four specimens)

Description: Edge trimming suggests preparation of blank for precise flake remova1. Length, $0.5 \mathrm{~cm}$ to $5.9 \mathrm{~cm}$; width, $1.7 \mathrm{~cm}$ to $5 \mathrm{~cm}$; thickness, $0.5 \mathrm{~cm}$ to $1.4 \mathrm{~cm}$.

Provenience: Zones 15, 15b (mixed 1ot), N3/E3 (one); Zones 17-23, Level 6, N2/E2 (one); Nọ provenience (two). 
Type II (five specimens)

Description: Flakes retouched for undetermined purpose. Length, $0.4 \mathrm{~cm}$ to $5.5 \mathrm{~cm}$; width, $2.5 \mathrm{~cm}$ to $4.2 \mathrm{~cm}$; thickness, $0.9 \mathrm{~cm}$ to $1.7 \mathrm{~cm}$.

Provenience: Zones 12, 13, 14 (mixed 1ot), N3/E3 (two); Zone 15b, N2/E3 (one); Zones 15, 15b (mixed lot), N3/E3 (one); Zones 17-23, Level 3, N2/E2 (one).

\section{Utilized Flakes (51 specimens)}

This category describes flakes or fragments which show no evidence of intentional preparation, but which appear to have been used as casual tools. Fortuitous concavities resulting from flake scars show some dulling or residue stain, but no edge trimming. Some sharp edges are torn or ragged in appearance, possibly due to incidental removal of smal1 chips from a freshly struck edge. In some instances, a beveled bit is present, indicating function as a tool, but lacking intentional trimming to a desired shape. Three "types" have been established on the basis of staining.

OPERATION 2 (36 specimens)

Type I (18 specimens)

Description: With black stain. Length, $1.6 \mathrm{~cm}$ to $9 \mathrm{~cm}$; width, $0.7 \mathrm{~cm}$ to $4 \mathrm{~cm}$; thickness, $0.1 \mathrm{~cm}$ to $1.4 \mathrm{~cm}$.

Provenience: Zones 12, 13, 14 (mixed 1ot), N2/E3 (two), N3/E3 (eight); Zone 14, N2/E3 (two), N4/E3 (three); Zone 15b, N2/E3 (three).

Type II (one specimen)

Description: With reddish stain. Length, $5.6 \mathrm{~cm}$; width, $4.8 \mathrm{~cm}$; thickness, $0.7 \mathrm{~cm}$.

Provenience: Zones 17-23, Leve1 1, N3/E3.

Type III (17 specimens)

Description: Without stain. Length, $1.8 \mathrm{~cm}$ to $8 \mathrm{~cm}$; width, $0.5 \mathrm{~cm}$ to $5 \mathrm{~cm}$; thickness, $0.1 \mathrm{~cm}$ to $1.4 \mathrm{~cm}$.

Provenience: Zone 15b, N2/E3 (one); Zones 17-23, Leve1 1, N2/E2 (one), Leve1 2, N2/E2 (two), Level 3, N2/E2 (nine); No provenience (four).

OPERATION 3 (15 specimens)

Type III (15 specimens)

Description: Without stain. Length, $1.5 \mathrm{~cm}$ to $7.3 \mathrm{~cm}$; width, $0.8 \mathrm{~cm}$ to $5.8 \mathrm{~cm}$; thickness, $0.2 \mathrm{~cm}$ to $2.1 \mathrm{~cm}$. 
Provenience: Zone 2, N8/E2 (four); Zone 4, N8/E1 (one), N9/E2 (two); Zone 5, N8/E1 (one); Zone 6, N9/E2 (one); Zone 7, N9/E1 (one), N10/El (one); Zone 8, N9/E3 (two), N9/E2 (two).

Cores (17 specimens)

The term core is used to describe depleted fragments of chert cobbles from which flakes have been repeatedly removed in the initial stages of lithic production. The series of facets, edges, and prominences created by this activity provides a variety of possible tool forms and, when exhausted as cores, these remnants may have been employed as choppers, scrapers, or gravers. Three "types" have been established on the basis of retouching or residue stain.

OPERATION 2 (15 specimens)

Type I (one specimen)

Description: Secondary retouch on one edge to form a working bit. Traces of residue on ventral face. Length, $9.5 \mathrm{~cm}$; width, $7 \mathrm{~cm}$; thickness, $2.9 \mathrm{~cm}$.

Provenience: Zones 17-23, Level 6, N2/E2.

Type II (two specimens)

Description: Secondary retouch on one end for use as scraper. No residue present. Length, $9.3 \mathrm{~cm}$ to $9.5 \mathrm{~cm}$; width, $6.5 \mathrm{~cm}$ to $7 \mathrm{~cm}$; thickness, $3.8 \mathrm{~cm}$ to 4.2 $\mathrm{cm}$.

Provenience: Zone 12 (surface), No provenience (one); Zones 17-23, Level 3, N2/E2 (one).

Type III (12 specimens)

Description: No secondary retouch, no residue stains. Length, $3 \mathrm{~cm}$ to $21 \mathrm{~cm}$; width, $2.2 \mathrm{~cm}$ to $10.5 \mathrm{~cm}$; thickness, $0.9 \mathrm{~cm}$ to $6.5 \mathrm{~cm}$.

Provenience: Zones 12, 13, 14 (mixed lot), N2/E3 (one), N3/E3 (three); Zone 14, N3/E3 (one), N4/E3 (one); Zone 16, N2/E3 (one); Zones 17-23, Leve1 1, N2/E2 (one), Level 3, N2/E2 (one), Level 7, N3/E1 (one); No provenience (one).

OPERATION 3 (two specimens)

Type III (two specimens)

Description: Exhausted cores, possibility utilized. No residue stains. Length, $6.5 \mathrm{~cm}$ to $10.2 \mathrm{~cm}$; width, $6.8 \mathrm{~cm}$ to $7.3 \mathrm{~cm}$; thickness, $1.9 \mathrm{~cm}$ to $4.9 \mathrm{~cm}$.

Provenience: Zone 7, N8/El (one); Zone 8, N9/E3 (one). 
Hammerstones (eight specimens)

Hammerstones are rounded chert cobbles and fragments with cherty-lime cortex showing edge pecking and battering from use as striking implements. This type of damage results from percussive removal of flakes in lithic tool manufacture, and also from battering of bones, nuts, and plant foods. One or more faces may show smoothing or discoloration as from grinding or abrading plant foods against another stone surface. Three specimens exhibit random striations such as those formed by platform preparation for flake removal.

OPERATION 2 (seven specimens)

Description: Length, $7.5 \mathrm{~cm}$ to $12 \mathrm{~cm}$; width, $6 \mathrm{~cm}$ to $12 \mathrm{~cm}$; thickness, $3.4 \mathrm{~cm}$ to $6.5 \mathrm{~cm}$.

Provenience: Zone 16b, N2/E2 (one); Zones 17-23, Level 3, N2/E2 (two), Level 4, N2/E2 (two), Level 5, N2/E2 (one), Leve1 7, N3/E1 (one).

OPERATION 3 (one specimen)

Description: Length, $7.7 \mathrm{~cm}$; width, $6.9 \mathrm{~cm}$; thickness, $5.5 \mathrm{~cm}$.

Provenience: Zone 7, N10/El.

Ground Stone (three specimens)

OPERATION 2 (three specimens)

Type I (one specimen)

Description: Irregular limestone slab with light striations on edges and both faces. Small areas of discoloration suggesting grinding or rubbing use, probably in food preparation. Diameter, $16 \mathrm{~cm}$; thickness, $4 \mathrm{~cm}$.

Provenience: Zones 17-23, Leve1 5, N2/E2.

Type II (two specimens)

Description: Irregular flat pebbles with one or more edges thinned and beveled by bifacial use. Specimen $A$ is made of hard limestone with striations on both sides and one end. Diameter, $4.5 \mathrm{~cm}$; thickness, $1.2 \mathrm{~cm}$. Specimen B is of dark brown quartzite, heavily polished and with a dark stain on beveled edge, probably from polishing activity. Thickness, $0.7 \mathrm{~cm}$; diameter, $3.1 \mathrm{~cm}$.

Provenience: Specimen A: Zones 17-23, Levels 1 and 2 (mixed); Specimen B: Zones 12, 13, 14 (mixed 1ot), N3/E3. 
Wood Artifacts

Operation 2 (26 specimens)

END MODIFIED (26 specimens)

Type I (14 specimens)

Description: Sticks or woody plant stalks with one or both ends cut at sharp angle and burned. Chopping marks clearly evident on some. Length, $3 \mathrm{~cm}$ to $18 \mathrm{~cm}$; diameter, $1 \mathrm{~cm}$ to $1.5 \mathrm{~cm}$.

Provenience: Zone 14, N2/E2 (one), N2/E3 (three); Zone 15, N4/E3 (one); Zone 15b, N2/E2 (three); Zones 17-23, Level 1, N2/E2 (two), Level 2, N2/E2 (one), Level 3, N2/E2 (one), Level 6, N2/E2 (one).

Type II (three specimens)

Description: One or both ends cut and burned into rounded blunt ends. Length, $11 \mathrm{~cm}$ to $14.5 \mathrm{~cm}$; diameter, $1.4 \mathrm{~cm}$ to $3.6 \mathrm{~cm}$.

Provenience: Zone 15b, N2/E2 (one); Zone 17-23, Level 2, N2/E3 (one), Leve1 3, N2/E2 (one).

Type III (nine specimens)

Description: Unburned sticks cut or shaped on one or both ends. Some chopping and peeling evident. Length, $9 \mathrm{~cm}$ to $23 \mathrm{~cm}$; width, $0.7 \mathrm{~cm}$ to $5 \mathrm{~cm}$; thickness, $0.9 \mathrm{~cm}$ to $5 \mathrm{~cm}$.

Provenience: Zones 12, 13, 14 (mixed 1ot), N3/E3 (two); Zone 14, N2/E2 (two); Zone 15, N4/E3 (one); Zone 15b, N2/E3 (one); Zone 16b, N2/E2 (two); Zones 17-23, No provenience (one).

Operation 3

END MODIFIED (three specimens)

Type I (two specimens; Fig. 25,a,b)

Description: Short sticks cut at sharp angle to form point on one end. 0ther end blunt on one specimen, round on other. Both ends burned on cut surfaces. Similar to those found by Word (Word and Douglas 1970:85, Fig. 38,D). Length, $8 \mathrm{~cm}$ to $11.3 \mathrm{~cm}$; diameter, $1 \mathrm{~cm}$.

Provenience: Zone 7, N9/E2 (one); Zone 8, N9/E2 (one). 
Type II (one specimen; Fig. 25,d)

Description: Wooden stake found in deposits in upright position. One end cut and broken. Chopping marks visible. Other end rounded and charred. Similar to that found by Word (Word and Douglas 1970:89, Fig. 40, F). Length, $20 \mathrm{~cm}$; diameter, $4.5 \mathrm{~cm}$.

Provenience: Zone $7, \mathrm{~N} 10 / \mathrm{E} 7$.

PERFORATED HOLLOW STEM (one specimen; Fig. 25,e)

Description: Length of hollow woody stem, both ends broken. Two holes $0.2 \mathrm{~cm}$ in diameter, drilled $0.5 \mathrm{~cm}$ apart on long axis, beginning $1 \mathrm{~cm}$ from one end. Length, $9 \mathrm{~cm}$; diameter, $0.6 \mathrm{~cm}$.

Provenience: Zone 3, N8/ET.

LASHED STICKS (one specimen; Fig. 25,c)

Description: Slightly curved section of peeled stick or woody plant stalk, both ends broken. Length, $31 \mathrm{~cm}$; diameter, $0.5 \mathrm{~cm}$. Twig fragment: length, $2.5 \mathrm{~cm}$; diameter, $0.3 \mathrm{~cm}$, lashed to long stick $6.5 \mathrm{~cm}$ from one end. Lashing of three strands of single fibers wound four times around both sticks (with one overhitch binding first two lashings between sticks), ending in square knot. One end of twig cut blunt, other end broken. Evidence of bark trimming on one side of twig.

Provenience: Zone 2, N9/E2.

Hide Artifacts

Operation 3 (five specimens)

POUCH OR GARMENT (one specimen; Fig. 26)

Description: Rectangular section of deer hide, -1 ength, $29 \mathrm{~cm}$; width, $11 \mathrm{~cm}$. Reddish hair adhering. Strip perforated at irregular intervals and double strand of split fiber inserted. Perforations made through double thickness of hide except at one end where four perforations occur $4 \mathrm{~cm}$ to $6 \mathrm{~cm}$ apart through a single thickness close to cut edge. Beginning about $8 \mathrm{~cm}$ from this cut edge, the sides are folded toward the center, the depth of the fold gradually increasing until, at the opposite end, the strip is folded in half. One length of split fiber lacing $83 \mathrm{~cm}$ long is threaded through perforations at three opposing positions.

Provenience: Zone 8, N9/E2. 


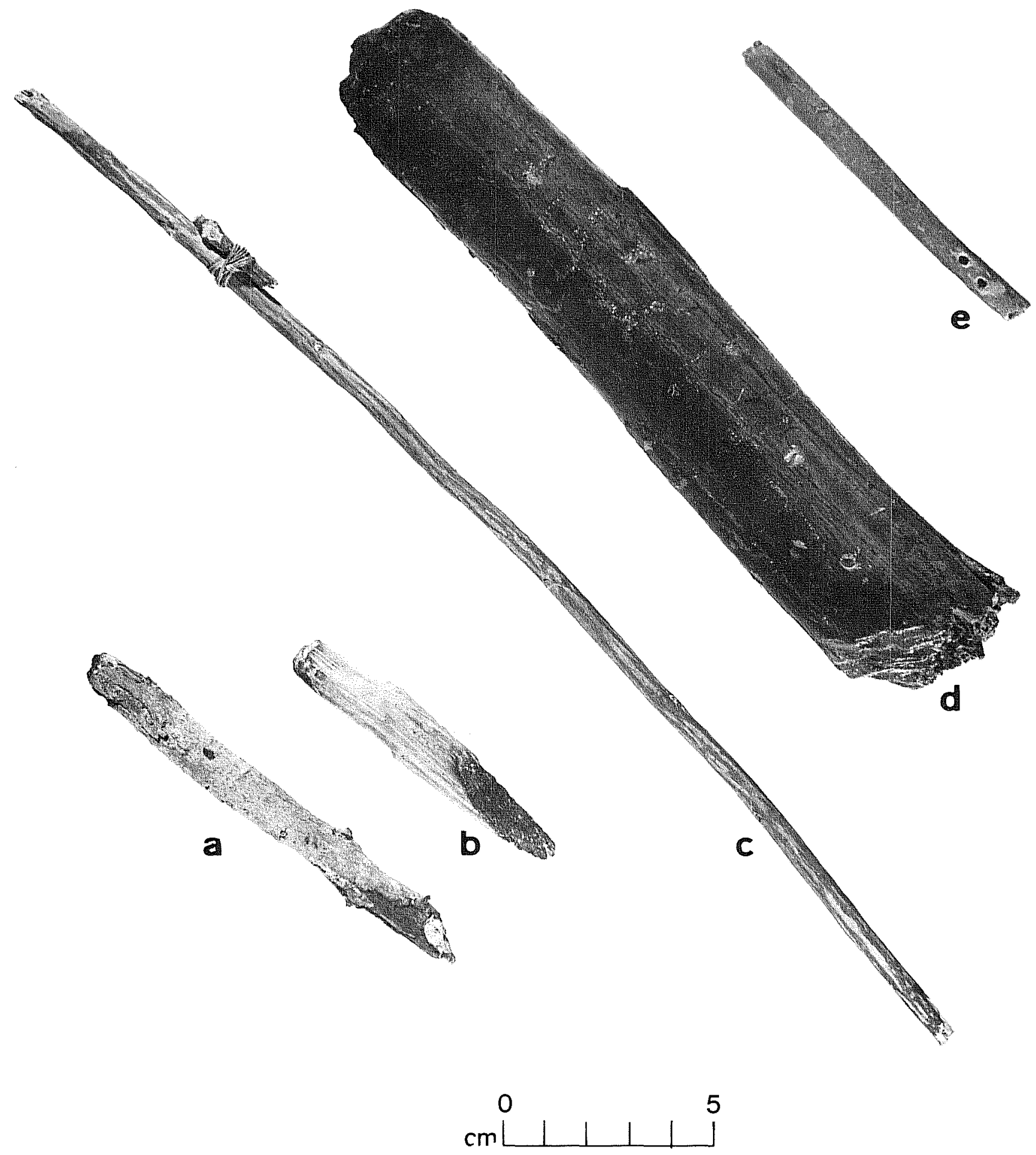

Figure 25. Wood Artifacts. a,b, cut and burned pointed sticks; c, lashed sticks; d, stake; e, perforated hollow stem. 

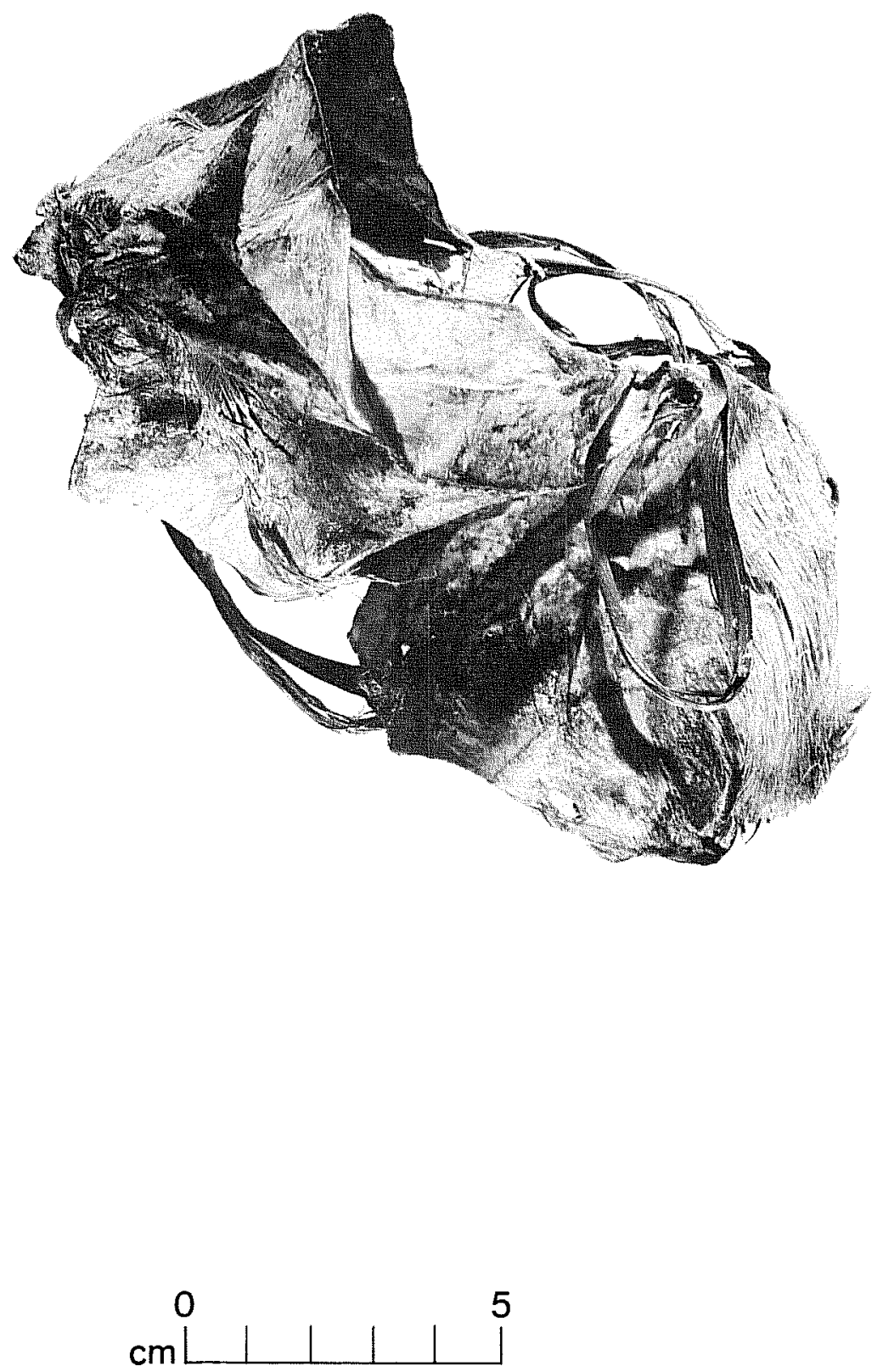

Figure 26. Deer Skin Pouch or Garment. Perforated and threaded with split fiber. 
PERFORATED HIDE STRIPS (three specimens; Fig. $27, \mathrm{~h}, \mathrm{i}$ )

Description: Narrow strips of hide roughly cut on one side, other side perforated in the center of irregular scallops along edge. Appear to be remnants of stretching procedure after finished hide was cut away. Similar to specimen found by Word (Word and Douglas 1970:96, Fig. 42,D). Length, $2.5 \mathrm{~cm}$ to $29 \mathrm{~cm}$; width, $0.3 \mathrm{~cm}$ to $2 \mathrm{~cm}$.

Provenience: Zone 4, N8/E1 (one); Zone 8, N8/E2 (one), N9/E3 (one).

HIDE-WRAPPED FIBER (one specimen; Fig. $27, \mathrm{j}$ )

Description: Fragment of three-strand, twisted fiber closely wrapped with narrow strips of fur-bearing hide. Length, $34 \mathrm{~cm}$; diameter, $1.7 \mathrm{~cm}$. Hide strips: width, $0.3 \mathrm{~cm}$ to $1.2 \mathrm{~cm}$ wound in overlapping spiral around core of fiber. Similar artifacts from Fate Bell Shelter are described as blanket weaving elements or tassel adornments (Pearce and Jackson 1933:91). Others from Shumla Caves are identified as remnants of fur robes by Schuetz (1963: 134).

Provenience: Zone 2, N8/E1.

Bone Artifacts

Operation 2 (12 specimens)

AWL OR PUNCH (one specimen; Fig. 27,a)

Description: Highly polished, rounded fragment tapering symmetrically to a fine point. Similar to specimen found by Word (Word and Douglas 1970:93). Opposite end cut or broken irregularly. Length, $5.7 \mathrm{~cm}$; diameter, $0.5 \mathrm{~cm}$.

Provenience: Zones 17-23, No provenience.

SMOOTHED OR POLISHED (four specimens)

Type I (two specimens; Fig. 27,c)

Description: Highly polished bone fragment in general conformation of awl but with both ends cut or blunted. Length, $5.5 \mathrm{~cm}$ to $7.5 \mathrm{~cm}$; diameter 0.4 to $0.7 \mathrm{~cm}$. Provenience: Zones 17-23, Level 2, N2/E2 (one); No provenience (one).

Type II (one specimen; Fig. 27,d)

Description: Smoothed fragment, one end shaped or worn into spatulate form. Length, $7 \mathrm{~cm}$; width at spatulate end, $0.7 \mathrm{~cm}$; thickness, $0.5 \mathrm{~cm}$.

Provenience: Zone 15b, N2/E3. 
Type III (one specimen; Fig. 27,e)

Description: This specimen was originally sorted into the bone artifacts group, but was later identified as a gar scale. There is no recognizable evidence of its use as an artifact. However, since Suhm, Krieger, and JeTks (1954:510) have suggested that some of these objects may have been used as arrow points, I have decided to leave the specimen within this group.

Provenience: Zones 17-23, No provenience.

CUT AND BURNED (four specimens)

Description: Fragments burned and shaped into a point on one or both ends. Length, $2 \mathrm{~cm}$ to $7 \mathrm{~cm}$; width, $0.6 \mathrm{~cm}$ to $1.2 \mathrm{~cm}$; thickness, $0.5 \mathrm{~cm}$ to $1.1 \mathrm{~cm}$.

Provenience: Zones 12, 13, 14 (mixed 1ot), N2/E3 (two); Zone 15b, N2/E3 (two).

CUT OR GNAWED (four specimens)

Description: Striations on edges or ends of bone fragments. Undetermined if result of gnawing by animals or intentional cutting or decoration by man. Length, $2 \mathrm{~cm}$ to $9.5 \mathrm{~cm}$; width, $1.8 \mathrm{~cm}$ to $1.9 \mathrm{~cm}$; thickness, $0.6 \mathrm{~cm}$ to $1.2 \mathrm{~cm}$.

Provenience: Zones 15b, N2/E3 (one); Zone 16, N3/E3 (two); Zones 17-23, Level 6, N2/E2 (one).

Operation 3 (two specimens)

AWL OR PUNCH (one specimen; Fig. 27,b)

Description: Split bone tapering to sharp point. Opposite end cut or broken. High polish on convex face. Length, $5 \mathrm{~cm}$; width at cut end, $0.3 \mathrm{~cm}$.

Provenience: Zone 7, N9/E3.

SMOOTHED OR POLISHED (one specimen)

Type IV (one specimen)

Description: Fragment of split bone, both ends cut or broken. High polish on convex face. Length, $2.5 \mathrm{~cm}$; width, $0.5 \mathrm{~cm}$.

Provenience: Zone 6, N10/El. 


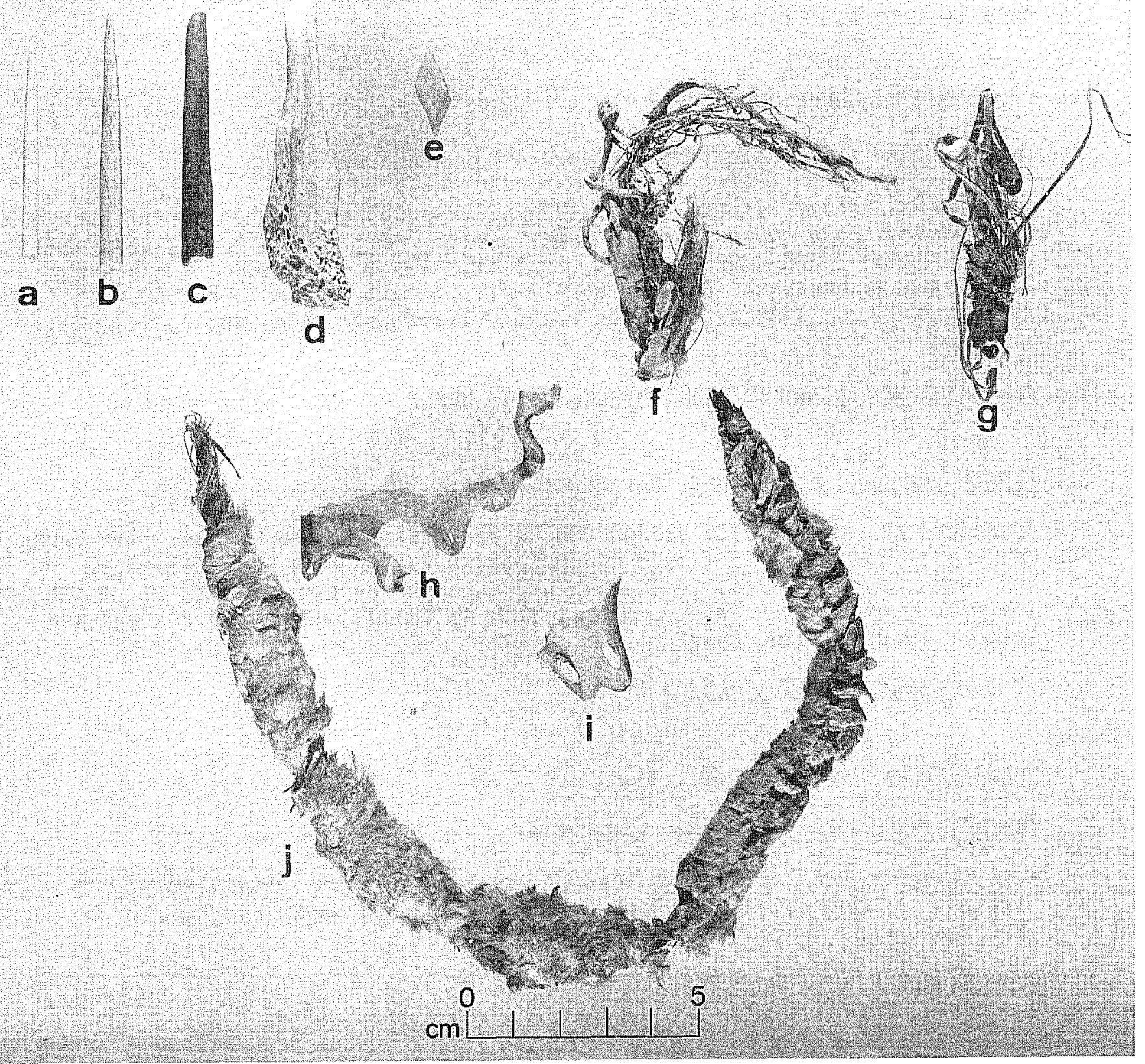

Figure 27. Bone, Hide, and Fiber Artifacts. a,b, awl or punch; c, polished bone (probably awl fragment); $d$, polished bone with spatulate end; e, gar scale; $f$, leaf pierced and threaded with split fiber; $g$, fiber-wrapped bone; $h, i$, perforated hide strips; $j$, hide-wrapped fiber. 


\section{Fiber Artifacts}

Sandals (five specimens)

Classification of sandals is after Schuetz (1956), who divided the Trans-Pecos sandals into four types.

\section{OPERATION 2 (three specimens)}

Type A, Biparallel Warp (two specimens; Fig. 28,a,b)

Description: Frame of two lechuguilla strips doubled back in center of sandal. Additional strips woven over and under across frame. Reinforcing strips originate from heel and extend to toe, bent over toe and rewoven into frame. Contrasted to heel, toe has no loose ends. Length, $21 \mathrm{~cm}$ to $24 \mathrm{~cm}$; width, $7.5 \mathrm{~cm}$ to $9 \mathrm{~cm}$. Similar to those found by Word (Word and Douglas 1970:66, Fig. 28).

Provenience: Zones 14, 15 (Pandale pit), N2/E2.

Type D, Opposed Warp Frame (one specimen; Fig. 28, c)

Description: Lechuguilla strips placed parallel, crossed at toe. Two ends woven back and forth in figure eight fashion toward heel. Toe and heel in this specimen unraveled and fragmentary. Length (estimated), $22 \mathrm{~cm}$; width at toe, $7 \mathrm{~cm}$; width at heel, $10 \mathrm{~cm}$. Similar to those found by Word (Word and Douglas 1970:66, Fig. 28).

Provenience: Zone 16, N3/E3.

OPERATION 3 (two specimens)

Type A, Biparallel Warp (one specimen)

Description: This specimen burned at the toe. Length (estimated), $24 \mathrm{~cm}$; length of fragment, $19 \mathrm{~cm}$; width at instep, $9.5 \mathrm{~cm}$; width at heel, $11 \mathrm{~cm}$. Ties present at instep close to heel.

Provenience: Zone 8, N9/E3.

Type D, Opposed Warp Frame (one specimen; Fig. 28,d)

Description: Ties are passed through sole at toe, crossing and re-entering opposite side of sole at instep. Ankle ties, if any, missing. Length, $19 \mathrm{~cm}$; width at instep, $6 \mathrm{~cm}$; width at heel, $7 \mathrm{~cm}$.

Provenience: Zone 8, N9/E2. 

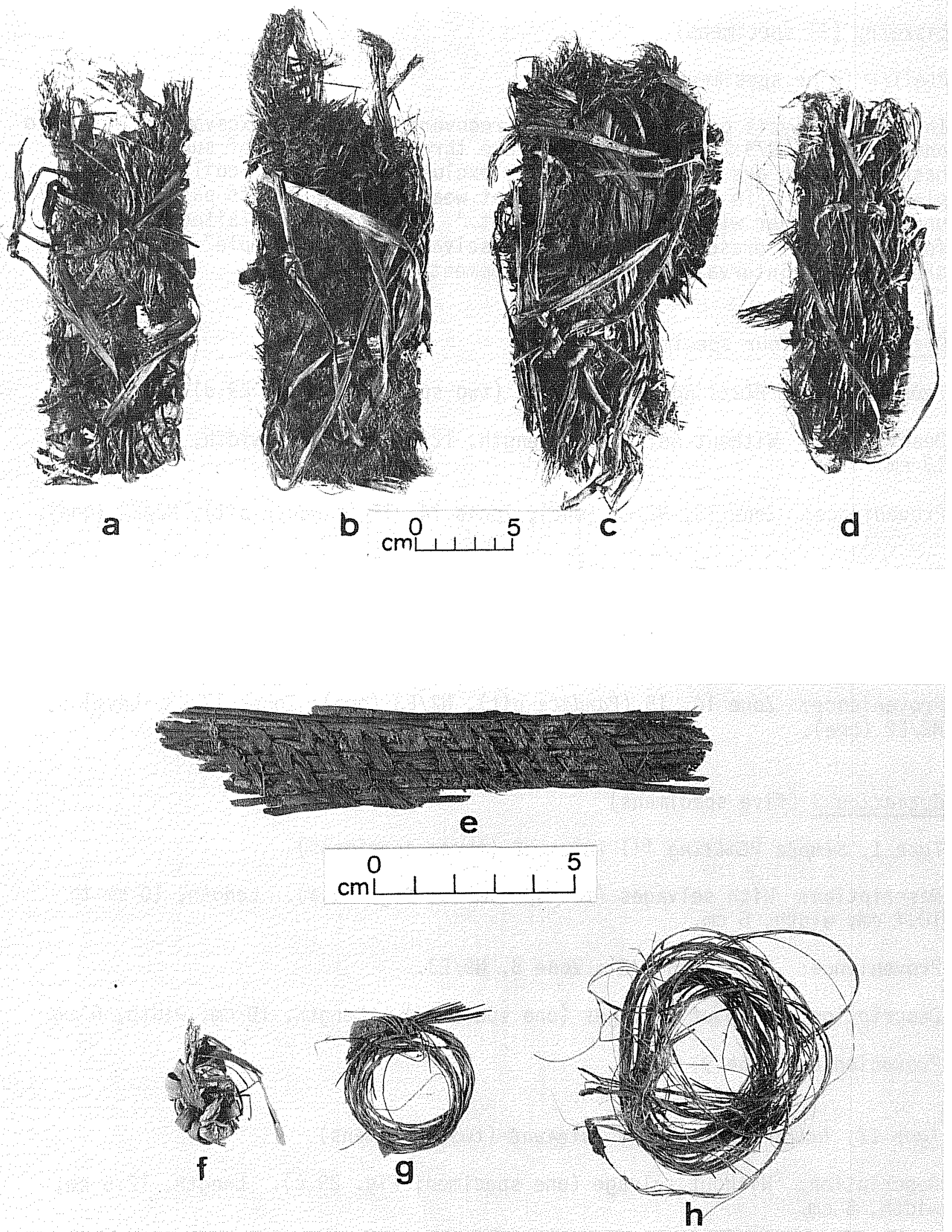

Figure 28. Fiber Artifacts. a,b, Type A sandals; c,d, Type D sandals; e, Type II coiled basketry; f, Type I coiled fiber; g, knotted circlet; $h$, wound circlet. (Scales differ.) 
Basketry (11 specimens)

PLAITED (nine specimens)

In their analysis of plaited matting recovered from this excavation, Adovasio and Andrews (1979:2) state: "There are three major kinds of sub-classes of basketry which are generally mutually exclusive: Twining, coiling and plaiting. . . . In this group of basket weaves, all elements pass over and under each other without any engagement." They classify plaited matting further on the presence or absence of selvages and as "Simple" or "Twill" on the basis of interval of element engagement.

Operation 2 (four specimens)

Type I, Simple Plaiting $1 / 1$ Interval (two specimens; Fig. 29,d)

Description: Without selvages. Length, $12 \mathrm{~cm}$ to $18 \mathrm{~cm}$; width, $10.5 \mathrm{~cm}$ to $13 \mathrm{~cm}$.

Provenience: Zone 13, N2/E2 (one); Zones 14, 15 (Pandale pit), N2/E3 (one).

Type II, Twill Plaiting 2/2 Interval (two specimens; Fig. 29,e)

Description: Without selvages. Length, $7.5 \mathrm{~cm}$ to $12.5 \mathrm{~cm}$; width, $6 \mathrm{~cm}$ to $9.5 \mathrm{~cm}$.

Provenience: Zone 14, 15 (Pandale pit), N2/E3 (one); Zones 17-23, Level 5, N2/E2 (one).

Operation 3 (five specimens)

Type I, Simple Plaiting $1 / 1$ Interval (three specimens)

Description: With selvages (two specimens; Fig. 29,a). Length, $10 \mathrm{~cm}$ to $10.7 \mathrm{~cm}$; width, $6 \mathrm{~cm}$.

Provenience: Zone 4, N10/E1; Zone 8, N9/E3.

Description: Without selvages (one specimen). Length, $10 \mathrm{~cm}$; width, $6 \mathrm{~cm}$.

Provenience: Zone 9, N9/E2.

Type II, Twill Plaiting $2 / 2$ Interval (two specimens)

Description: Without selvage (one specimen; Fig. 29,c). Length, $12.5 \mathrm{~cm}$; width, $8 \mathrm{~cm}$.

Provenience: Zone 2, N9/E2. 

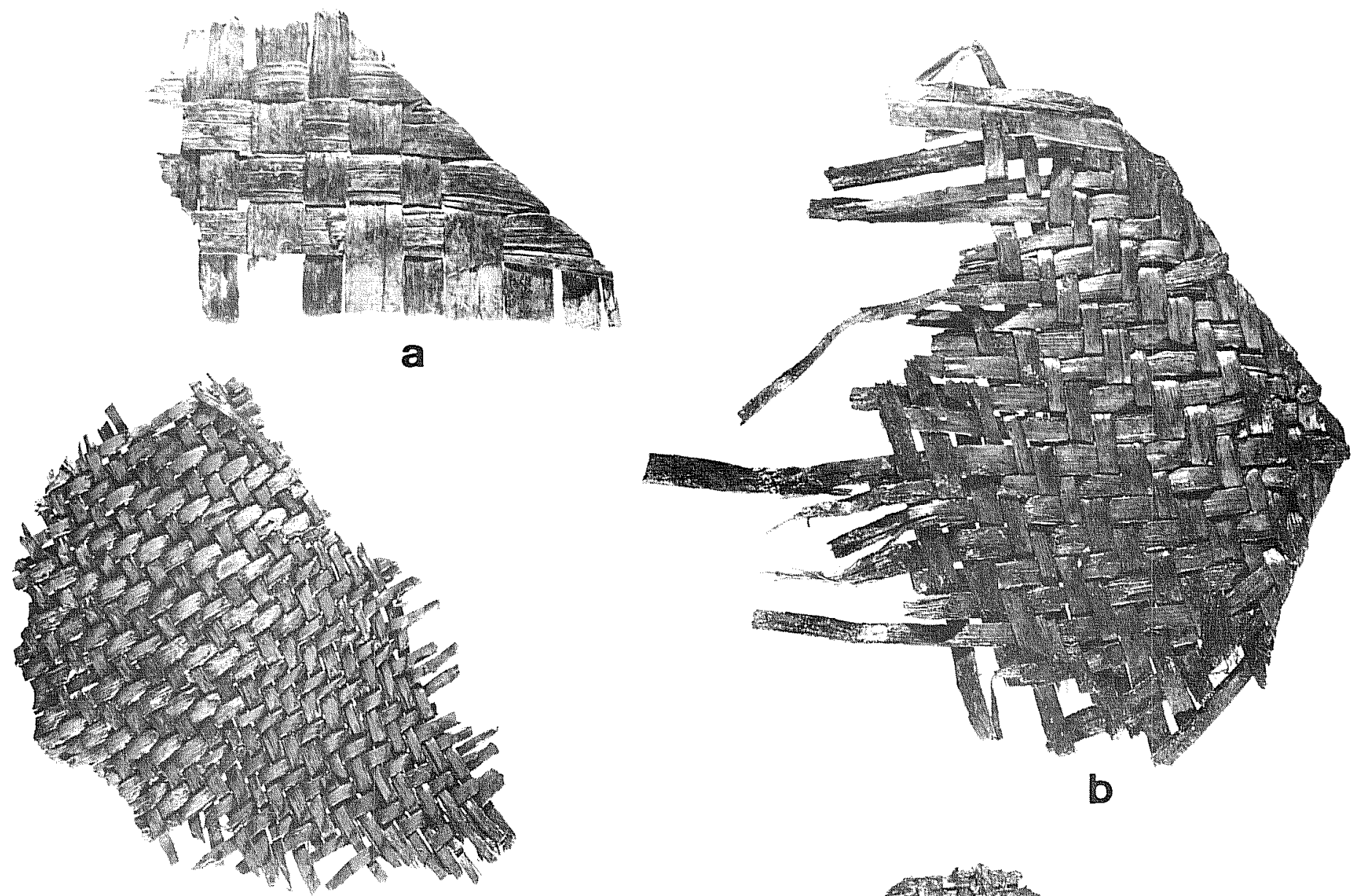

b
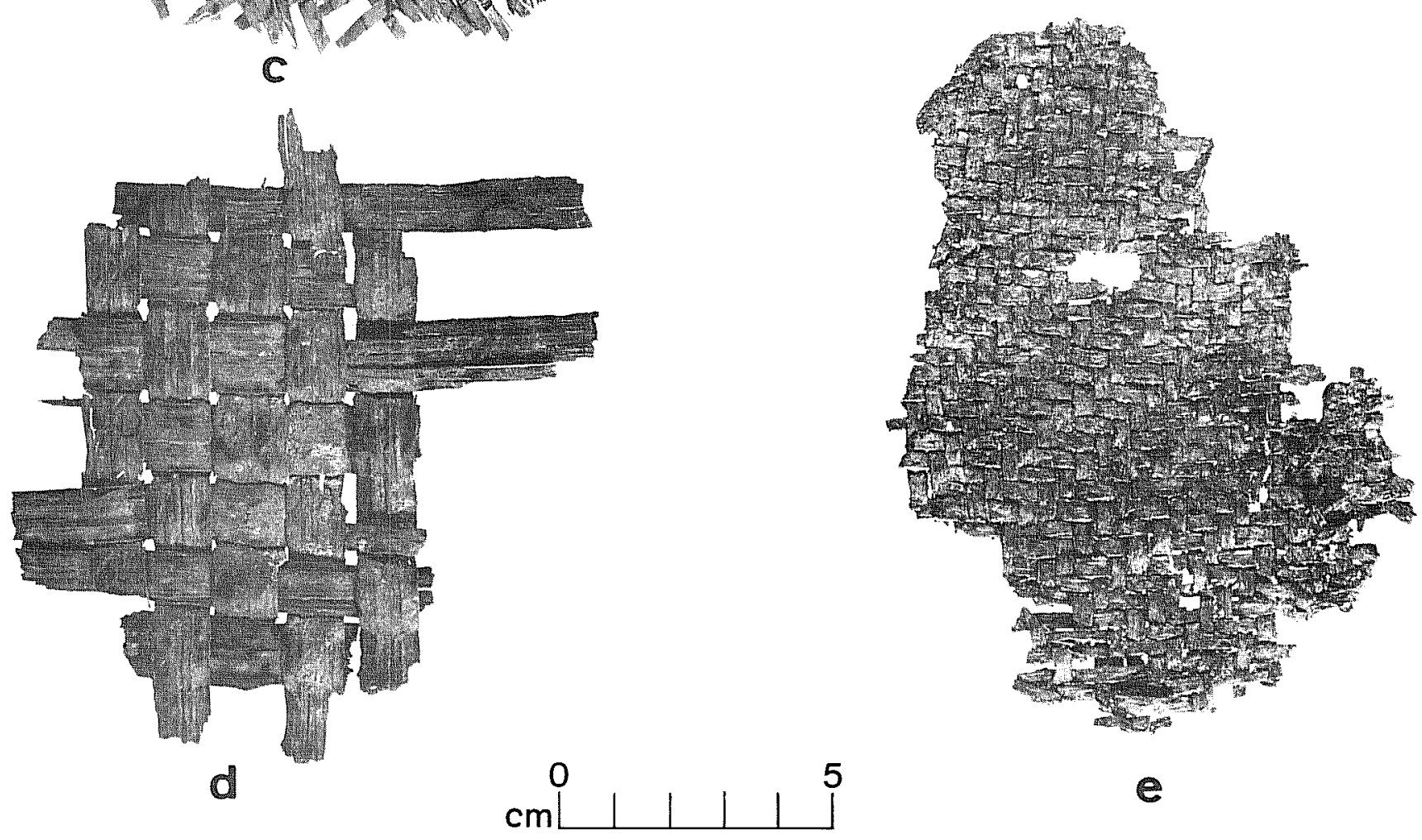

Figure 29. Plaited Basketry. a, simple plaiting with selvage; $b$, twill with selvage; $c$, twill without selvage; d, simple plaiting without selvage; e, twill without selvage. 
Description: With selvage (one specimen; Fig. 29,b). Length, $15 \mathrm{~cm}$; width, $14.5 \mathrm{~cm}$.

Provenience: No provenience (surface).

COILED (two specimens)

Andrews and Adovasio (1980:2) state: "The term coiling denotes a sub-class of basket weaves manufactured by sewing stationary, horizontal elements (the foundation) with moving vertical elements (stitches)." On the basis of this definition, but without their specific classification, this report describes two types.

Operation 2 (one specimen)

Type 1 (one specimen)

Description: In the original analysis, this specimen was interpreted as a fragment of coiled basketry. The heavy application of preservative had obscured many details and the specimen appeared to consist of five bundles of two or three rods wrapped tightly with split fiber. Length was $6 \mathrm{~cm}$; width, $2.5 \mathrm{~cm}$; and thickness, $1.5 \mathrm{~cm}$. Upon reexamination at a later date, this specimen was found to be a portion of sotol seed pod. Since it is already included in tables herein, we have retained this description as a cautionary note.

Provenience: Zone 14, N4/E3.

Operation 3 (one specimen)

Type II (one specimen; Fig. 28,e)

Description: Flat fragment, one side finished as rim. Bundles of two or three rods laced tightly. Joined by passing split fiber over bundle, under second bundle, over third bundle, etc. Length, $14 \mathrm{~cm}$; width, $2.5 \mathrm{~cm}$. Similar to Type VI:Close Coiling, Whole Rod Foundation as classified by Andrews and Adovasio (1980:53, Fig. 17).

Provenience: Zone 4, N10/ET.

Knotted Fiber (127 specimens)

Seven different kinds of knots, as described by Word (Word and Douglas 1970), were recovered from this excavation. Overhand, slipknots (running overhand), and square knots were most numerous. Fibers were primarily of sotol and lechuguilla. Some specimens had been knotted at intervals as many as 12 times and are tabulated as one specimen and categorized according to the most frequent type of knot used. Length, $0.5 \mathrm{~cm}$ to $29 \mathrm{~cm}$. Untied knots are grouped as "fragments." 
OPERATION 2 (88 specimens)

Overhand (26 specimens)

Provenience: Zone 13, N4/E3 (one); Zone 14, N3/E3 (one); Zones 15, 15b (mixed lot), N3/E3 (one); Zone 15b, N2/E2 (three), N2/E3 (one); Zone 16, N2/E2 (eight), N2/E3 (one), N4/E3 (one); Zones 17-23, Level 5, N2/E2 (one), Level 6, N2/E2 (one); No provenience (seven).

Slipknot (Running Overhand) (25 specimens)

Provenience: Zone 14, N2/E2 (four), N2/E3 (five), N3/E3 (two), N4/E3 (two); Zone 15b, N2/E2 (seven), N2/E3 (one); Zones 15, 15b (mixed 1ot), N3/E3 (one); Zone 16, N2/E2 (one); Zones 17-23, Leve1 1, N2/E2 (two).

Square (12 specimens)

Provenience: Zone 13, N4/E3 (one); Zones 12, 13, 14 (mixed 1ot), N3/E3 (one); Zones 14, 15 (Pandale pit), N2/E3 (one); Zone 15b, N2/E2 (one); Zone 16, N2/E2 (six); No provenience (two).

Granny (eight specimens)

Provenience: Zone 13, N4/E3 (one); Zone 14, N2/E2 (one), N2/E3 (two), N4/E3 (two); Zones 12, 13, 14 (mixed 1ot), N3/E3 (one); Zone 15b, N2/E2 (one).

Bowline (one specimen)

Provenience: Zone 14, N2/E3.

Larkshead (one specimen)

Provenience: Zones 12, 13, 14 (mixed 10t), N3/E3.

Fragments (15 specimens)

Provenience: Zone 14, N3/E3 (two); Zones 12, 13, 14 (mixed 1ot), N3/E3 (two); Zone 15, N2/E3 (one), N4/E3 (one); Zone 15b, N2/E2 (one), N2/E3 (one); Zones 15, $15 \mathrm{~b}$ (mixed lot) N3/E3 (one); Zone 16, N4/E3 (one); No provenience (two); Zones 17-23, Level 1, N2/E2 (two), Level 8, N2/E2 (one).

OPERATION 3 (39. specimens)

Square (17 specimens)

Provenience: Zone 2, N8/E2 (two), N9/ET (one), N9/E2 (four), N10/E2 (one); Zone 4, N8/E1 (one), N9/E2 (two), N10/E1 (two); Zone 6, N9/E2 (one); Zone 7, N8/E2 (one), N9/ET (one), NTO/E3 (one). 
Slipknots (nine specimens)

Provenience: Zone 2, N10/E1 (one); Zone 5, N8/El (two); Zone 6, N9/E2 (two), NTO/E2 (two); Zone 8, N9/E2 (two).

Overhand (six specimens)

Provenience: Zone 2, N9/El (one); Zone 4, N9/El (one); Zone 5, N8/El (one); Zone 7, N10/E2 (one); Zone 8, N9/E2 (one), N9/E3 (one).

Larkshead (four specimens)

Provenience: Zone 2, N8/E2 (one); Zone 6, N10/E2 (one); Zone 8, N9/E2 (two).

Bowline (two specimens)

Provenience: Zone 3, N9/E2 (one); Zone 4, N8/E1 (one).

Halfhitch (one specimen)

Provenience: Zone 6 , N10/E2 (one).

Cordage (31 specimens)

"Fibers are the basic elements of cordage. . . . Cordage is formed when two or more strands are twisted together in an opposite direction to the twist of the strands. . . . Short lengths of cordage can be made by twisting a strand tightly and then allowing it to twist back on itself" (Word and Douglas 1970: 68). A1l cordage recovered from this excavation was Z-Twisted (clockwise), as opposed to S-Twisted (counterclockwise). Length, $1.1 \mathrm{~cm}$ to $40 \mathrm{~cm}$; diameter, $0.1 \mathrm{~cm}$ to $1 \mathrm{~cm}$.

OPERATION 2 (22 specimens)

Type I (10 specimens)

Description: With knots (all overhand).

Provenience: Zone 12, N4/E3 (one); Zone 14, N2/E3 (three), N3/E3 (one); Zone 15, N2/E2 (one); Zone 15b, N2/E3 (two); Zones 17-34, Level 1, N2/E2 (one); Level 2, N2/E2 (one).

Type II (12 specimens)

Description: Without knots. 
Provenience: Zone 12, N4/E3 (one); Zone 14, N3/E3 (one); Zones 12, 13, 14 (mixed lot), N3/E3 (three); Zone 15b, N2/E3 (one); Zones 15, 15b (mixed 1ot), N3/E3 (one); Zone 16, N2/E2 (one); Ho provenience (one); Zones 17-23, Leve1 1, N2/E2 (two), Level 2, N2/E2 (one).

OPERATION 3 (nine specimens)

Type II (nine specimens)

Description: Without knots.

Provenience: Zone 1, N7/E2 (one); Zone 4, N9/E1 (one), N9/E2 (one); Zone 5, N9/El (one); Zone 6, N8/E2 (one), N10/E2 (one); Zone 7, N9/E7 (one); Zone 8, N9/E2 (one); No provenience (projecting from east wall about $25 \mathrm{~cm}$ below final level of excavation) (one).

Netting (six specimens)

Cordage knotted into open squares, forming fabric of mesh. Diameter, $0.1 \mathrm{~cm}$ to $1 \mathrm{~cm}$; fragments, $3 \mathrm{~cm}^{2}$ to $10 \mathrm{~cm}^{2}$.

OPERATION 2 (four specimens)

Provenience: Zone 14, N3/E3 (two); Zone 15b, N2/E2 (one); Zone 16, N2/E2 (one).

OPERATION 3 (two specimens)

Provenience: Zone 4, N9/E2 (one); Zone 6, N9/E2 (one).

Coiled Fiber (nine specimens)

TYPE I (two specimens; Fig. 28,f)

Description: Fragment of stiff fiber twisted into tight circle and wrapped with split fiber; possibly beginning of basket base. Diameter of circle, $10.5 \mathrm{~cm}$; thickness of coil, $1.5 \mathrm{~cm}$.

Operation 2 (one specimen)

Provenience: Zone 16, N2/E2.

Operation 3 (one specimen)

Provenience: Zone 5, N9/ET. 
TYPE II (seven specimens)

Description: Fine fiber or grass wound into smal1 circlets. Diameter, $3.5 \mathrm{~cm}$ to $7 \mathrm{~cm}$.

Operation 3 (seven specimens)

Description: With knots (overhand or square) (five specimens; Fig. 28,g)

Provenience: Zone 4, N9/E2 (one); Zone 5, N9/E1 (two); Zone 6, N10/E2 (two).

Description: Without knots (two specimens; Fig. 28,h).

Provenience: Zone 2, N10/E2 (one); Zone 4, N9/E1 (one).

Nestlike Constructions (three specimens)

Description: Ball-shaped constructions of grass and bark with depressions in center. May be rodent nests or may be containers for seeds and nuts. Diameter, $15 \mathrm{~cm}$ to $17 \mathrm{~cm}$; height $4 \mathrm{~cm}$ to $5 \mathrm{~cm}$; depth of central depression $2 \mathrm{~cm}$ to $2.5 \mathrm{~cm}$.

OPERATION 3 (three specimens)

Provenience: Zone 5, N8/ET (one); Zone 7, N10/ET (one); Zone 8, N9/E3 (one).

Prickly Pear Artifact (one specimen; Fig. 27,f)

Description: Fragment of prickly pear leaf pierced and threaded with split

fiber. Interpreted as water bags or multipurpose pouches by Alexander (1970:50).

OPERATION 3 (one specimen)

Provenience: Zone 7, N10/ET.

Folded Fiber (one specimen)

Description: Stack of five split lechuguilla fibers folded continuously

into flat bundle. Length, $3.3 \mathrm{~cm}$; width of fiber elements, $0.3 \mathrm{~cm}$.

OPERATION 2 (one specimen)

Provenience: Zone 16, N2/E2. 
Miscellaneous Artifacts with Fiber (two specimens)

OPERATION 3 (two specimens)

Type I Fiber-Wrapped Bone (one specimen; Fig. 27,g)

Description: Split fiber wrapped. 1oosely about central portion of rabbit humerus. Length, $5 \mathrm{~cm}$.

Provenience: Zone 3, N8/ET.

Type II Fiber and Hair (one specimen)

Description: One frayed, split fiber with hair or fur attached.

Provenience: Zone 8, N10/ET.

\section{ANALYSIS OF PLANT REMAINS}

Materials from the large cooking pit found in association with the Golondrina point (Operation 2, Zones 17-23, Level 7) were bagged according to their position within the hearth. They were processed through three tiers of USA Standard testing sieves, decreasing in mesh size from \#12 (1700 microns) to \#35 (500 microns) to \#100 (150 microns). Plant and animal remains were picked from the top and middle sieves. Unsorted fine residue (mostly ashy soil) not passing through the \#100 mesh was rebagged and preserved. Approximately half the hearth fill is retained unprocessed in storage.

A set of seeds and leaves from this deposit was sent to Texas A\&M Anthropological Laboratories where they were identified by Phil Dering through comparison with reference materials. Twenty-five pieces of charcoal were selected at random from the sample, and identification of the woods were made by Liz Porter, using a 40X scope and reference collection. Flowers, fruits, seeds, and wood charcoal from 16 plant species were identified from this matrix (Table 6). Dering considers the species count normal for a burned context, in which heat usually destroys some plant species. He finds evidence of a heavy utilization of streamside and canyon varieties, with walnut fragments predominating. Upland fruits such as prickly pear and hackberry were also harvested, but remains of lechuguilla and sotol, considered staple foods of the lower Pecos Archaic period, were not found in the hearth.

Woods identified from the hearth were dominated by oak and buckeye (canyon varieties), hackberry (upland), and juniper (both canyon and upland). These probabiy represent dead wood gathered for fire building, and Dering notes that much oak and buckeye dead wood occurs in the canyons, and often several trunks of a desert hackberry will die and can be removed without damage to the plant itself.

A preliminary pollen scan of the hearth matrix was conducted in 1976 by Ed Luther, University of California at Berkeley. Eleven plant varieties were identified, and in addition, the pollen grains, while somewhat low in count, were found to be well preserved (Table 6). 
TABLE 6. IDENTIFICATION OF PLANT REMAINS FROM THE GOLONDRINA COMPLEX HEARTH FILL

SEEDS AND FRUITS (in order of abundance)

\begin{tabular}{|c|c|c|}
\hline Scientific Name & Common Name & Ripening Time \\
\hline $\begin{array}{l}\text { Juglans microcarpa } \\
\text { Opuntia spp. } \\
\text { Diospyros texana } \\
\text { Celtis reticulata } \\
\text { Celtis pallida } \\
\text { Prosopis glandulosa } \\
\text { Quercus spp. } \\
\text { Sophora secundiflora } \\
\text { Ungnadia speciosa } \\
\text { Setaria lutescins } \\
\text { Viqueria stenoloba } \\
\text { Mahonia or Berberis trifoliata } \\
\text { Vitis arizonica } \\
\text { Acacia berlandieri } \\
\text { Karuinskia humboldtiana } \\
\text { Rhus microphylla }\end{array}$ & $\begin{array}{l}\text { Texas black walnut } \\
\text { prickly pear } \\
\text { persimmon } \\
\text { net-leaf sugar hackberry } \\
\text { spiny hackberry } \\
\text { honey mesquite } \\
\text { oak } \\
\text { Texas mountain laurel } \\
\text { Mexican buckeye } \\
\text { Plains bristlegrass } \\
\text { skeleton-leaf goldeneye } \\
\text { agarita } \\
\text { canyon grape } \\
\text { guajillo } \\
\text { coyotillo } \\
\text { littleleaf sumac }\end{array}$ & $\begin{array}{l}\text { Fal1 (October) } \\
\text { July-September } \\
\text { July-September } \\
\text { August-Septembe } \\
\text { July-August } \\
\text { August-Septembe } \\
\text { September } \\
\text { October } \\
\text { June } \\
\text { July-August } \\
\text { June-July } \\
\text { October } \\
\text { May-July }\end{array}$ \\
\hline \multicolumn{3}{|c|}{ WOOD (in order of abundance) } \\
\hline $\begin{array}{l}\text { Quercus spp. } \\
\text { Juniperus spp. } \\
\text { Ungnadia speciosa } \\
\text { Celtis spp. } \\
\text { Acacia spp. } \\
\text { Platanus occidentalis } \\
\text { Prosopis glandulosa } \\
\text { Larrea tridentata }\end{array}$ & $\begin{array}{l}\text { oak } \\
\text { juniper } \\
\text { Mexican buckeye } \\
\text { hackberry } \\
\text { guajillo } \\
\text { sycamore } \\
\text { honey mesquite } \\
\text { creosote bush }\end{array}$ & \\
\hline
\end{tabular}

POLLEN (in order of abundance)

Quercus sp.

High spine Compositae (Helianthus type)

Low spine Compositae (Ambrosia type)

Graminae

Pinus $\mathrm{sp}$.

Chenopodiaceae/Aramanthaceae

Onagraceae

Ephedra sp.

Unbell iferae

Rhamnaceae

Typha sp. oak

sunflower

ragweed

grass family

pine

goosefoot family

primrose family

Mormon tea

cow parsnip family

buckthorn family

cattail

SOURCE: Hester (1980:140, Table 6.1). 
Plant macrofossils recovered from the $1 / 4$-inch field screening of Operation 2 materials, exclusive of the hearth, were also identified by Dering. Seeds or leaves of 21 different plants were identified, showing a heavy exploitation of walnut, the presence of pecan, and a very smali amount of lechuguilla fruit (Table 7). Dering observed no major differences between the Pre-Archaic and Early Archaic (Pandale) horizons, in terms of plant use and availability.

\section{ANALYSIS OF ANIMAL REMAINS}

Identification of animal remains from the 1976 excavations at Baker Cave was done by means of comparative vertebrate collections. Estimates of the minimum number of individuals (MNI) within each unit involved the counting of specific skeletal elements with regard to the symmetry (left versus right), the size, age at death, and sex where discernible.

Reptiles from the Golondrina complex hearth fill were identified by Thomas Van Devender, Arizona Natural Heritage Program, Tucson; mammals by Van Devender, Melissa Winans, and Kenneth J. Lord, the latter two of The University of Texas at Austin; and fish remains by Lord. A list of these identifications is given in Table 8.

Materials from the noncultural basal zone (Operation 2, Zones 17-23, Level 8), underlying the Golondrina stratum, were processed in the same manner as those from the hearth fill. Reptiles and mammals from the basal zone were identified by Van Devender; birds by Amadeo M. Rea, Museum of Natural History, San Diego; and fish by Michael L. Smith, University of Michigan, Ann Arbor. These are presented in Table 9.

Skeletal material from the remainder of Operation 2 and all of Operation 3 , both coarse (1/4-inch) and fine (1/8-inch) recovery, was analyzed by Harold G. Wooldridge, The University of Texas at Austin. Identification of snake and lizard species from this portion is still in process. A list of these identifications is presented in Table 10.

With a few exceptions, the fauna recovered from Operation 2, Zones 17-23, Levels 7 and 8 , are of species represented in the area today. In the hearth fil1, a raccoon jaw was identified as that of an extinct species, Procyon lotor simus. One species of fish, the blue sucker, (Cycleptus elongatus) and two species of snakes, the glossy snake (Arizona elegans) and the hooknosed snake (Gyalopion canum) were identified, but are not 1 isted as extant in the region by Scudday and Hanselka (1975). The harvest mouse (Reithrodontomys sp.), identified in Level 7 outside the hearth and also in Level 6 , is not listed as extant by Scudday and Hanselka (1975), nor was it identified by Douglas (Word and Douglas 1970) in specimens from earlier Baker Cave excavations. These specimens from the 1976 recovery may have been detected, however, because of the very fine screening process used.

The turtle plastron found in situ in the basal zone (Level 8) was identified as that of a pond turtle (Chrysemys picta) which no longer occurs in the area. According to Van Devender (personal communication), the pond turtle is found in the upper Pecos and Rio Grande in New Mexico, and it has a relict population 
TABLE 7. IDENTIFICATION OF PLANT REMAINS FROM OPERATION 2, EXCLUSIVE OF THE GOLONDRINA COMPLEX HEARTH FILL

SEEDS (in order of abundance)

Scientific Name

Common Name

Early Archaic Level

Juglans microcarpa

Quercus spp.

Yucca spp.

Diospyros texana

Ungnadia speciosa

Carya illinoiensis

Karwinskia humboldtiana

Sophora secundiflora

Acacia berlandieri

Cucurbita foetidissima

opuntia spp.

Juniperus spp. littleleaf walnut

oak

yucca

persimmon

Mexican buckeye

pecan

coyoti110

Texas mountain laure1

guajil10

buffalo gourd

prickly pear

juniper

Pre-Archaic Level

Juglans microcarpa

Yucca spp.

Quercus spp.

Prosopis glandulosa

Diospyros texana

ungnadia speciosa

Acacia berlandieri

Celtis pallida

Carya illinoiensis

Vitis arizonica

Allium drummondii

Juniperus spp.

Cucurbita foetidissima

Celtis reticulata

Agave lecheguilla littleleaf walnut

yucca

oak

honey mesquite

persimmon

Mexican buckeye

guaji110

- spiny hackberry

pecan

canyon grape

onion

juniper

buffalo gourd

net-7eaf sugar hackberry

lechuguilla

\section{Late Paleo-Indian Level}

Juglans microcarpa

quercus spp. littleleaf walnut oak 
TABLE 7. (cont.)

LEAVES (in order of abundance)

Scientific Name

Common Name

Early Archaic Level

Opuntia spp.

Dasylirion texanum

Quercus virginiana

Jatropha dioica

Diospyros texana prickly pear soto 1

live oak

Sangre de Cristo (1eatherstem) persimmon

Pre-Archaic Leve]

Opuntia spp.

Quercus virginiana

Quercus vaseyana

Diospyros texana

Celtis pallida

Carya illinoiensis

Berberis trifoliata prickly pear

live oak

shinnery oak

persimmon

spiny hackberry

pecan

agarita

Late Paleo-Indian Level

Quercus virginiana

live oak 
TABLE 8. IDENTIFICATION OF FAUNAL REMAINS FROM THE GOLONDRINA COMPLEX HEARTH FILL ${ }^{1}$

Scientific Name

Common Name

Source

Mamma ls

Carnivora

Chiroptera

Citellus variegatus

Citellus sp.

Dipdomys sp.

Lepus californicus

Neotoma sp.

onychomys sp.

Perognathus sp.

Peromyscus sp.

Procyon lotor simus

Sigmodon hispidus

Spilogale sp.

Sylvilagus sp.

Thomomys bottae

urocyon of cinereoargenteus lyinx or coyote

bat

rock squirre]

ground squirre 1

kangaroo rat

blacktailed jackrabbit wood rat

grasshopper mouse

pocket mouse

whitefooted mouse

raccoon

hispid cotton rat spotted skunk

cottontail rabbit

Western pocket gopher

gray fox
W

W

L

W, L

$\mathrm{L}$

L

$\mathrm{L}$

V

$W, L$

$W, L$

W, V

W, L

$w$

W, L

L

W, L

Reptiles 2

Arizona elegans

crotalus atrox

Crotalus molossus

crotalus sp.

Crotaphytus collaris

Elaphe guttata or absoleta

Eumeces obsoletus

Gyalopion canum

Hypsiglena torguata

Lampropeltis getulus

Lampropeltis mexicana

Lampropeltis triangulum

Masticophis or Coluber

Phrynosoma cornutum

Pituophis melanoleucus

Rhinocheilus lecontei

Salvadora sp.

Sceloporus sp.

Sonora semiannuta

Tantilla or Diadophis punctatus

Thamnophis proximus glossy snake

Western diamondback

rattlesnake

blacktailed rattlesnake

rattlesnake

collared lizard

Great Plains or Texas

ratsnake

Great Plains skink

hook-nosed snake

night snake

common kingsnake

gray-banded kingsnake

milksnake

coachwhip or racer

Texas horned lizard

bull snake

long-nosed snake

patch-nosed snake

lizard

ground snake

black-headed or ringneck snake

ribbon snake 
TABLE 8. (cont.)

Scientific Name

Common Name

Source

Fish $^{2}$

Carpiodes carpio

Cycleptus elangatus

Ictiobus bubalus

Lepomis sp.

Micropterus salmoides

Moxostoma congestum carp sucker

blue sucker

small mouth buffalo

sunfish

large mouth bass

gray redhorse sucker

${ }^{1}$ From 1 to 3 individuals represented in each species.

${ }^{2}$ After Hester 1980:141, Table 6.2).

SOURCE: W: Winans, L: Lord, V: Van Devender.

in Rio Santa Maria in northwest Chihuahua in Mexico. Chrysemys scripta (pond slider) and C. concianna (river cooter) are found in the Devil's River today. Arizona elegans was also identified from the basal zone.

Van Devender reports that most of the reptile specimens recovered from the hearth were in its lower portion. Some were charred, and some were digested but not burned. All rattlesnake remains had been burned. All represented relatively large specimens (about four feet long), and the Sceloporus were also of a larger body size than are those lizards today.

Notable by their absence from Levels 7 and 8 are the rock rattlesnake (Crotalus lepidus), the most common rattler in the region today, the copperhead (Agkistrodon contortrix), and the coral snake (Micrurus fulvius).

As tabulated by Wooldridge, faunal remains from Operation 2, exclusive of the hearth fill in Level 7 and all of Level 8, indicate a variable pattern of increase and decrease through time in number of species and minimum number of individuals (MNI). A rapid increase is observed from Zone 12 to Zone 15b, followed by a sharp decrease at Zone 16. Faunal recovery remains at a low level (with minor fluctuations) until Level 4 of Zones 17-23. A sharp increase is then evident through Level 6 .

The faunal groups which represent this pattern (fish, rabbits, and rodents) do not fluctuate in concert; e.g., rabbits may decrease in frequency as rodents increase. The incidence of rodents follows most closely the pattern formed by the total number of species and MNI. A11 three groups, however, decrease markedly during Level 3 of the Pre-Archaic (Zones 17-23, Levels 1-6), and fish remains, while numerous in Level 1 and Level 4, are absent from both Level 2 and. Level 3. Faunal elements recovered from Level 3 represent one individual 
TABLE 9. IDENTIFICATION OF FAUNAL REMAINS FROM CULTURALLY STERILE BASAL ZONE

Scientific Name

Common Name

Mamma $1 \mathrm{~s}$

Lepus sp.

Neotoma sp.

Sigmodon sp.

jackrabbit

wood rat

cotton rat

\section{Reptiles}

Arizona elegans

Chrysemys picta

Hypsiglena torquata

Masticophus or Coluber

Pituophis melanoleucus

Rhinocheilus lecontei

glossy snake

pond turtle

night snake

coachwhip or racer

bull snake

long-nosed snake

Amphibians

Hylactophryne augusti

scaphiopus couche

barking frog

Western spadefoot toad

Fish

Ictalurus sp.

Ictiobus bubalus

Micropterus salmoides

Moxastoma congestum catfish

small mouth buffalo

large mouth bass

gray redhorse sucker

Birds

Anas cf platyrynchos

Fulica americana

Lophortyx gambelii or callipepla squamata

zenaida macroura dabbling duck, referred to mallard American coot

Gambel's quail or scaled quait mourning dove

NOTE: From 1 to 3 individuals represented in each species. 
each of porcupine, Mexican pocket gopher, cottontail rabbit, and jackrabbit. Fish and rodents were responsible for the large increase in MNI in Zones 15 and 15b; the incidence of rabbits decreased in that deposit. A17 three groups participated in the increase at Levels 4 and 5 , but fish and rodents continued the increase to Level 6, with rabbits decreasing after Level 5.

Deer and pronghorn elements were recovered from Zones 12-16, and deer from Zones 17-23, Level 1 and Level 5.

Fluctuations in number of species and MNI in Operation 3 follow a more regular pattern, demonstrating an increase in Zone 2, a decrease in Zone 3 which is maintained to Zone 4, and then dramatic increases in Zones 5 and 7 , alternating with decreases in Zones 6 and 8 . The three selected faunal groups also fluctuate in unison, with the exception of rodents, which remain at a level of one individual per zone until Zone 5, when their incidence increases, and they assume the same pattern of alternation as the other two groups. Fish are predominant in Zone 2 and are present throughout.

The number of deer/pronghorn in Operation 3 is fairly constant in all zones (MNI-1), except in Zone 7, where no artiodactyl elements were identified even though this is a zone of major increase. Deer or pronghorn was identified from Zone 8 .

A11 fauna identified from Operation 3 are of modern species.

Wooldridge also tabulates the fauna from this excavation according to biotic zones and preferred habitat. He notes that three major zones are recognizable within the assemblage. He describes the Riparian niche as being represented by two species of duck, two types of water turtles, and the fish. Deer, turkey, and the white-footed mouse, he points out, favor a Mixed Scrub Forest niche, while pronghorn and jackrabbits prefer a Grassland Prairie zone. Animals he lists as adaptable enough to occur in all three habitats include the owl, bobcat, fox, eagle, canis, vulture, dove, and quail. He explains that transitional zones meeting the criteria of type and depth of soil may support gophers and the pocket mouse or, with certain topographical features such as rocky canyons, may be inhabited by the rock squirrel and Mexican pocket gopher. A few, he points out, are found in either of two zones, such as Riparian and Mixed Scrub Forest, which support cottontail rabbit, spotted skunk, porcupine, raccoon, and cardina1, or Mixed Scrub Forest and Grassland Prairie, in which we find the cotton rat, harvest mouse, and box turtle.

In the tabulation of number of species by habitat, Wooldridge finds that Riparian or Riparian-Mixed Scrub Forest species predominate in this inventory. In Operation 2, these species show a decreasing pattern (with minor fluctuations) from Zone 15b, where they are most abundant, downward to Level 2 of the Pre-Archaic. At this level they are overtaken for the only period by species representing the Grassland Prairies or the Mixed Scrub Forest-Grassland Prairie combination. They resume their dominance in Level 3 and increase gradually to Level 6 where there is a sharp increase. Assuming that a representative sample is indicated by the reduced excavation at the lower levels, Wooldridge (1978: 41) feels that "the data strongly suggest that the Riparian and Riparian-Mixed Scrub Forest habitats formed the major exploitation strategy, and the species 
TABLE 10. IDENTIFICATION OF FAUNAL REMAINS FROM OPERATION 2 (EXCLUSIVE OF GOLONDRINA COMPLEX HEARTH FILL AND BASAL ZONE) AND OPERATION 3

Mamma 1s

Sylvilagus sp.

Neotoma sp.

Lepus californicus

Citellus sp.

Sigmodon hispidus

Odocoileus virginianus/

odocaileus hemionus

citellus variegatus

Peromyscus sp.

Crategeomys castanops

Thomomys sp.

Canis latrans/Canis familiaris/

Canis lupus

Geomys sp.

Antelocapra americana

Perognathus sp.

Spilogale putorius

Procyon lotor

Reithrodontomys sp.

Urocyon cinereoargenteus

Erethizon dorsatum

Lynx rujus

$\begin{array}{lr}\text { cottontail rabbit } & 47 \\ \text { woodrat } & 27 \\ \text { jackrabbit } & 19 \\ \text { ground squirrel } & 16 \\ \text { hispid cotton rat } & 15 \\ & \\ \text { deer } & 12 \\ \text { rock squirrel } & 10 \\ \text { white-footed mouse } & 8 \\ \text { Mexican pocket gopher } & 7 \\ \text { pocket gopher } & 5 \\ & \\ \text { canine } & 4 \\ \text { pocket gopher } & 4 \\ \text { pronghorn antelope } & 3 \\ \text { pocket mouse } & 3 \\ \text { spotted skunk } & 3 \\ \text { raccoon } & 2 \\ \text { harvest mouse } & 2 \\ \text { gray fox } & 2 \\ \text { porcupine } & 1 \\ \text { bobcat } & 1\end{array}$

spiny softshe11 turtle

pond slider

ornate box turtle

5

1

1 bobwhite quail

red-headed duck

cardinal

golden eagle

ring-necked duck

great-horned ow1
47

27

16

15

12

10
8
7

7

5

4

4

3

3

2

2

2

1
Birds
Colinus virginianus

Aythya americana

Richmondena cardinalis

Aquila chrysactos

Aythya collaris

Bubo virginianus

sis

Chrysemys sp. 
TABLE 10. (cont.)

Scientific Name

Common Name

MNI 1

Birds (continued)

Cathartes aura
Meleagris gallopavo
Zenaidura macroura

Fish turkey vulture

wild turkey

mourning dove
1

7
Micropterus sp.

Ictalurus furcatus

Ictiobus sp.

Moxostoma congestum

Lepisosteus sp.

Carpiodes sp.

Ictalurus punctatus

Cichlasoma cyanoguttutum

Aplodinotus grunniens

Lepomis $\mathrm{sp}$. bass

blue catfish

buffalo fish

red-horse sucker

gar

carp sucker

channel catfish

Rio Grande perch

drum

sunfish
19

16

13

9

4

3

3

2

1

IMinimum number individuals.

dwelling therein (the cottontail rabbits, fish and deer) were the staples of the meat portion of the diet."

The same dominance is exhibited in Operation 3, with a regularly fluctuating but consistently more numerous representation of these two Riparian-influenced groups. Species found solely in the Mixed Scrub Forest habitat are absent from al1 levels except Zones 5, 7, and 8, each of which contained the remains of only one species from this group. Specimens representing the Grassland Prairie group are nearly as scarce, there being two species identified in Zone 5 .

Wooldridge stresses the point that all animal remains in an archaeological site do not necessarily result from cultural factors. Contextual data, such as that from the sealed hearth in the Golondrina stratum, or modification of bone as evidenced by ornamentation, tool manufacture, or butchering marks, indicate unequivocal association with habitation sites. He points out that the presence of burned material without context may not be definitive, since both cultural and noncultural burning occur. Cooking usually burns only that 
portion of the bone directly exposed to the fire and would not be reflected in a large percentage of the total. Burning in a refuse pit results in charring of most, but not a17, of the bone. In his tabulation of burned vs. unburned identifiable bone elements, Wooldridge finds the greatest percentage of burned bone among the deer/pronghorn specimens (25\%), followed by those of the carnivores $(27.27 \%$ ), probably indicating their use as food. From the tabulation of unidentifiable bone fragments, three items are significant in his view: almost half the fragments from Operation 2, Zones 12-14, show burning; Zones 15-15b contained more burned than unburned fragments and, in Operation 3, more than $43 \%$ of the fragments recovered from Zone 8 were burned. These percentages, he feels, indicate habitational activity, arguing against accidental combustion because of the percentage of unburned fragments.

In analyzing subsistence strategies, Wooldridge finds the distribution of artiodactyls somewhat surprising. No diagnostic elements were recovered from Operation 3 which would differentiate between deer and pronghorn, and an environmental interpretation cannot be made. The occurrence of these remains in six of the eight zones, however, indicates that they were taken (even if occasionally) to supplement the fish and rabbits in the diet. Diagnostic elements were found in Operation 2, and Zones 12-14 contained two pronghorn and one deer. Zone 15-15b had one of each, and Leve1s 1 and 5 of the Pre-Archaic contained the remains of one deer each. A possible shift from Mixed Scrub Forest species (deer) to the Grassland Prairie species (pronghorn) might be inferred from the appearance of pronghorn in Zone 15-15b and its increase in Zones 12-14, but insufficient data above Zone 12 throughout the upper zones representing the Middle Archaic, precludes knowledge of the continuation of this pattern. If the artiodactyls in the Operation 3 units were, indeed, pronghorn, the other Grassland Prairie species, the jackrabbit, should show a corresponding increase over cottontail rabbits. This is not the case. Except for Zone 16b, where there is a jackrabbit present without a cottontail rabbit, both species increase in concert. Douglas reports deer from all zones of Word's excavation, and Wooldridge feels that, since Word's sample size was much larger, incorporation of his data provides a more complete estimate of conditions relating to the larger animals.

Douglas' analysis indicates that stream exploitation occurred only in Word's Zones 4 and 5 (our Operation 3 , Zones 6,7 , and 8 ), and that rabbits increased throughout the excavation as deer decreased. These inferences are contradicted by the specimens from the 1976 excavation, due, Wooldridge believes, to our fine-screen recovery of the smaller fish and rabbit elements.

Consolidation of both data sets indicates to Wooldridge that species of the Riparian habitat formed the major subsistence source, and that artiodactyls were taken, but not in sufficient numbers to justify the "big game hunting" appellation usually accorded these early inhabitants. Only four deer. were reported by Douglas as occurring during the Paleo-Indian period. Based on the continuum of fauna represented in both his and Douglas' analyses, Wooldridge (1978:48) hypothesizes that "the occupants of Baker Cave had adopted a gathering strategy extending back to and including the Paleo-Indian component." This view is supported by the large quantity of edible plant remains identified in the hearth fill (Table 6) and the recurring concentrations of walnut shel1s and other edible plants and seeds throughout the Pre-Archaic (Table 7). 
Carnivores, including in a broad sense, omnivores and scavengers, are represented by the spotted skunk, the canids, bobcat, fox, porcupine, and raccoon. of a total of 12 individuals identified by Wooldridge, 11 were recovered from Operation 2. Seven burned elements of canid and fox were recovered from the lower three levels and may be considered a supplementary food source. The remains of one spotted skunk were recovered from Operation 3, Zone 5, but did not exhibit cultural modification or burning. These predatory species may be responsible for the preponderance of rodent bones in the earlier levels. of the rodents recovered from Baker Cave, $72 \%$ were found in Operation 2, Zones 17-23, Levels 1-7, where $83.3 \%$ of the carnivores and $65 \%$ of the birds were also recovered (Wooldridge 1978:50). This may indicate that, prior to $3500-$ 3350 B.C., human occupation of Baker Cave was of a sporadic, short-term nature, periodically leaving the shelter open to use by carnivores.

of the nine species of birds identified by Wooldridge, the most numerous is the bobwhite quail, present in seven of the 20 levels examined by him, and the only bird recovered from more than two levels. Seasonality of the site may be inferred from the red-headed duck and ring-necked duck found in the lower Levels 6 and 7, both migratory species which might be found in the region in spring and fall. These are pond ducks which require a considerable body of water in order to take flight. Cultural modification was inferred by Wooldridge from the burning of at least one of the three red-headed ducks. The only other evidence of seasonality was noted in the recovery of a golden eagle from Level 5 of the Pre-Archaic. This region would be in the eagle's range from fall until spring. In general, Wooldridge finds that birds are not present in sufficient numbers to indicate that they were more than an occasional food source.

No bird remains were identified from the analyzed portion of the Golondrina hearth fill. The basal zone (Level 8) yielded (in addition to mourning dove and quai1) two aquatic species: the American coot or mudhen and a duck of either the mallard or dabbling duck species.

of the three types of turtles identified by Wooldridge, the spiny softshell was found in four zones and is the only species occurring more than once. The box turtle, common to the plains and scrub forest, was found in Zone 15, and the pond slider in Zone 15b. He concludes that turtles are present in insufficient numbers to be considered a dependable food source.

\section{SUMMARY AND CONCLUSIONS}

It is premature to describe the occupational cycle at Baker Cave with any certainty, but many inferences may be drawn from the information at hand. From the data now available, it appears that the shelter was not occupied by humans earlier than 7300 B.C. to 7000 B.C. According to the three-stage environmenta 1 progression proposed for the lower Pecos (Bryant 1969), this would have taken place during the transitional second stage, when open woodland areas of pinyon pine and juniper were replaced by parkland. Pine, rare in this region today, was detected in early Baker Cave pollen. This early cultural deposit attained approximately $30 \mathrm{~cm}$ in thickness and rested upon about $60 \mathrm{~cm}$ of cultural1y sterile limestone dust and spall accumulated upon bedrock. 
Plant remains identified from a basin-shaped cooking pit or hearth sealed within this zone indicate a predominant exploitation of riverine and canyon varieties. A preliminary pollen count and a plant macrofossil analysis of $50 \%$ of the hearth fill indicate that the desert plants sotol and lechuguilla were not present. A more moist climate could be indicated by the presence of a pond turtle no longer found in the area, recovered immediately below the bottom of the hearth. The larger size of a raccoon jaw and of the reptiles recovered from the hearth may be attributable either to a more mesic environment or to a longer life in the absence of human predation. Seeds and fruits identified from this hearth are primarily of varieties which ripen in late summer and early fall. A fall occupation is strongly suggested by the predominance of littleleaf walnut fragments and is supported by evidence of cultural modification of migratory ducks in this stratum.

A projectile point of the Golondrina type and an unfinished specimen, which is probably a preform of the same type, were found near the hearth in this stratum, and samples of wood charcoal found near them have been assigned radiocarbon dates of 7070 B.C. and 7230 B.C. Also recovered from this component was a triangular tool of the clear Fork type, with plant residue staining the dorsal and ventral sides of its bit. No points of the classic Plainview type (8200 B.C.) were recovered in this or previous excavations at the site. With the exception of one apparently reworked specimen described as "Plainview-like" by Word (Word and Douglas 1970:34), all Paleo-Indian points found by Word and Greer were classified by them as Plainview golondrina. The morphological characteristics of the Golondrina, flaring basal corners and a deep basal notch on a lanceolate outline, had apparently been well established before the earliest known occupation of Baker Cave at about 7000 B.C.

Our 1 ithic recovery (in addition to the points and the clear Fork tool) included a core, a hammerstone, two distal fragments of bifacial implements, four scrapers (one made on a blade), eight primary flakes, 27 secondary flakes, 360 interior flakes, and 34 flake fragments. A burin, with typical burin spalls struck vertically from the edge, was recovered from the basal spall just below the occupational zone and is bel ieved to have migrated from that zone.

The matrix of the Golondrina stratum was primarily of damp, gray limestone dust flecked with charcoal and mixed with decayed fiber and wood. Two areas of moderate rodent disturbance were observed. At least five discrete areas of charcoal, in addition to the cooking pit, were noted, and animal and fish bones were present throughout. This distinctive stratum was described by both Word (Zone I) and Greer (Zone 25), and it was from this level that their Late PaleoIndian points were recovered. In his Zone I, Word perceived two strata toward the front of the shelter and three in the middle. The term "strata" is used by him to describe "divisions within the zone (which) exhibit more subtle differences" (Word and Douglas 1970:10). Within these strata he describes structureless lenses of charcoal. Considerable lithic debris, mostly of large size, was recovered from his Zone I. The quantity of 1 ithic debris, as well as plant and animal remains, recovered in 1976 from the hearth suggests its use for trash disposal as well as for cooking. Evidence of separate incidents of fire use, and the careful manner in which the final fire was extinguished, point to some delineation of activity areas and, if not clearly an effort toward tidiness, at least some preference for safety or sanitation. Interviews 
by field anthropologists of modern Maidu Indians in the Modoc Valley of northeastern California record that fishbones are often burned because they "don't want children to step on them" (Voegel in 1942:178).

The horizontal extent of the early occupation has not been determined, but it is known to extend at least $7.3 \mathrm{~m}$ in a northeast direction, the length of Word's trench from the back wall (Figs. 5 and 8), and at least three meters to the southeast, the distance from Word's profile, through our excavation to the southeast wall of Greer's Unit 24 (Fig. 8).

The depth and extent of the Golondrina stratum point to a long term use of the shelter by Late Paleo-Indian inhabitants, but whether the occupation was continuous or sporadic is not clear. The poorly preserved fiber gives us no clue regarding its use and, although thin fiber lenses were noted, the matrix contains rotted fiber throughout. Scattered concentrations of charcoal and the separate incidences of burning in the cooking pit tell us only that separate fires were built, but 1 ittle can be deduced concerning chronological occurrence or group size. Douglas feels that the presence of deer of all age groups in each occupational zone (fawns and yearlings in equal numbers with mature individuals) indicates a year-round use. Wooldridge feels that seasonal use, primarily during the fall, is indicated by migratory ducks and eagles, unless availability of water might have prevailed at times other than spring and fal1. Granting the probability of a more intensive use during the fall harvest and migration season, in my view, the extent of the occupation and depth and relative uniformity of its deposit argue strongly for continuous rather than sporadic use. This is not to say that members of the group did not forage at some distance in their food procurement activities. Shafer (1981) has said of these early inhabitants of the lower Pecos:

- . they scheduled their movement and settlement in accordance with the seasonal availability of resources but also foraged opportunistically, taking advantage of exceptionally good yields and second fruitings... or the sudden appearance of a bison herd on the grassy uplands.

The large amount of usable floor space at Baker Cave, together with its cool summer breezes and relatively mild winter temperatures, would have rendered it an attractive year-round base camp.

Immediately above the clearly defined Golondrina component lay a very loose, unstable deposit, averaging one meter in thickness (our Zones 17-23, Levels 1-6). It contained projectile points classified as Stemmed, Unstemmed, Early CarnerNotched, and Early Triangular, but not identifiable within the descriptive limits of widely accepted typology (see Description of Artifacts section). Plant and animal remains were abundant, as was habitational refuse, and some concentrations of charcoal and pockets of walnut fragments were in place. A few occupational lenses of fiber were detected, but rodent disturbance was so severe as to obliterate any clear evidence of occupational strata. The stratigraphic placement and artifact assemblage from this unconsolidated deposit would place it within a "Pre-Archaic" period, as proposed by Sollberger, Hester, and others. It has been radiocarbon dated at $6730 \mathrm{~B}$. C. at $45 \mathrm{~cm}$ above its lowest level and, near its upper level, at 3500 B.C., in close temporal 
agreement with Word's Zone II (Word and Douglas 1970:99) and Story's Period II, covering the span from 7000 B.C. to 4000 B.C. (Story and Bryant 1966:2).

Fiber and wood decomposition decreased toward the upper levels. Above Level 1 of the Pre-Archaic lay $15 \mathrm{~cm}$ to $18 \mathrm{~cm}$ of dry, white Timestone dust, sterile in appearance, but containing seeds, charcoal, flint flakes in abundance, and two Early Triangular points. This "sterile" zone was present at this depth throughout all three excavations to date and is evident in Word's profile (Fig. 6) between his Zones II and III.

Seeds and leaves identified from the Pre-Archaic component represent much the same dominance of riverine and canyon varieties noted in the Golondrina stratum, with walnuts present in the greatest number. Lechuguilla appears in this inventory in a very smal1 quantity: four fragments of a fruit pod, weighing 1.5 grams.

Animal remains decreased sharply and steadily (both in number of species and MNI) from Level 6 upward to Level 3. A moderate increase occurred in Level 2 , followed by another decrease at Level 1. Low faunal recovery then continued through the white limestone deposit above. The only notable aberration in this pattern is seen in the steady decrease in fish remains, which began in Leve1 5. Fish were totally absent from both Levels 2 and 3 and were the only one of the representative groups which increased in number during the deposit of white 1 imestone spall.

Because of the obvious displacement and mixing by burrowing, it is difficult to draw any meaningful conclusions from the vertical distribution of these animal remains. It may be worth noting that Level 3 is the only level yielding no fiber artifacts whatever, but recovery of artifacts of preserved fiber did not occur in significant numbers in any of the Pre-Archaic below Level 1. Lithic artifacts and waste, however, were found in a fairly uniform pattern throughout this deposit, the only notable increase occurred in Level 6 (Table 2).

The zone of white 1 imestone dust lay $30 \mathrm{~cm}$ below Greer's bench, which formed the surface of Operation 2 excavations. Within that span, six zones of alternating fiber and dust deposits were detected. Pandale points predominated in the 1 ithic tool recovery, placing this occupation in an Early Archaic context and in temporal agreement with Story's Period III (4000 B.C. to 2500 B.C.) (Story and Bryant 1966:2). Weir (1976:64) dates the Pandale between 2840 B.C. and 2150 B.C., within his Clear Fork phase. Well preserved artifacts of fiber, wood, and bone were found in increasing number and variety within this context.

Plant remains identified from this period were of the same varieties identified from the lower levels, with the exception of sotol leaves, which first appear in this context. Faunal remains increase sharply and are still dominated by species preferring Riparian or Riparian-Mixed Scrub Forest habitats. The numerous fish remains account for this dominance, although rabbits and rodents also show a small increase. Faunal remains decrease in number toward the surface of the excavation.

Detailed studies are now in progress at Texas A\&M University to reconstruct the environmental record of plant and animal remains at Hinds Cave, excavated in 1975 and 1976. Dering (1979:52) reports a radiocarbon date of $9120 \pm 90$ B.P. (Tx-2866) from the earliest cultural level examined to date at Hinds Cave, 
indicating that occupation there was at least as early as was the Golondrina occupation at Baker Cave $(9180 \pm 220$ B.P.; RL-828). However, climatic conditions at Hinds Cave have proved much more xeric, and well-preserved sandals and fiber artifacts were encountered in a deposit radiocarbon dated at $8280 \pm 80$ B.P.; Tx-2314 (Shafer and Bryant 1977:77). The date of $8080 \pm 80$ B.P. $(T x-2930)$ was obtained from the lower levels of the Pre-Archaic at Baker Cave, where the deposit was damp and preservation very poor.

Hinds Cave occurs at an elevation of $430 \mathrm{~m}$ (1400 feet) above ms 1 (WilliamsDean 1979:23), some 400 feet lower than Baker Cave, and lies 30 air miles to the west, in what has been described earlier as the sotol-1echuguilla environment of the lower Pecos. Dering (1977) finds that the people of Hinds Cave and Baker Cave were exploiting essentially similar environments during the Early and Middle Archaic, but he reports sotol and lechuguilla in the earliest deposits at Hinds Cave and finds their absence from the Golondrina hearth most significant. Other differences noted by him include the overwhelming proportion of walnuts in Baker Cave, the abundance of pecans in Baker Cave and their absence from Hinds Cave, the higher proportion of prickly pear to sotol and lechuguilla in Baker Cave and the reverse in Hinds Cave, and the presence only of lechuguilla fruit, but no leaves, in Baker Cave. Lechuguilla is almost equal to sotol in Hinds Cave. He finds the differences in plant resources consistent with present-day conditions in which the same trees important to the lower Pecos aboriginal economy grow much larger in the vicinity of Baker Cave, and woody plants are comparatively profuse along the Devil's River, whereas the banks of the Pecos River near Hinds Cave are relatively bare.

The geographic factors of elevation and distance from a principal humidifying source (in this case, the Gulf of Mexico), resulting in subtle differences in rainfal1, temperature, and soil depth, must be taken into account in ascribing temporal sequence on the basis of a presumed general climatic shift. The absence of desert vegetation and the presence of aquatic animals in the lower Tevels of Bake Cave do not, on their evidence alone, imply that more mesic conditions prevailed in general during the Late Paleo-Indian period. It is, Tikewise, hazardous to conclude on the basis of Hinds Cave analyses that, 6300 years ago, southwest Texas and northern Mexico had already become a near desert.

The horizontal stripping of cultural zones in Operation 3 led to the conclusion that layers of fiber were intentionally placed as surfaces for food preparation and consumption, and probably for other activities. Areas of dust at the same level as fiber layers were found to contain large amounts of cultural debris and may have served for disposal of potentially hurtful lithic waste and animal bones. Zones of dust were not found to form continuous lenses over a wide area, thereby suggesting a hiatus in occupation between layers of fiber. Rather, it appears that fiber was placed in 7 imited patches, only to the extent required. Compression of the layers, resulting in a downward slope toward the mouth of the shelter, suggests intensive use. It is recommended that the method of open area stripping be applied on a larger scale to test these assumptions, and also to refine the occupational sequence. Wooldridge notes that we have seven levels from Operation 3 representing approximately the same time span of Word's Zone $V$, and that stripping of the cultural layers is the better 
approximation of the reality of each occupation. The case for fine screening is well made in the far greater recovery of small bones and plant remains from the 1976 excavation.

Finally, the limited research design with specific objectives is demonstrated as extremely successful in meeting its goals and, given precise methodology, sometimes exceeding them.

Much of this very important site remains to be examined. Additional careful excavation of Baker Cave and the use of improved analytical techniques will undoubtedly contribute significantly to our knowledge of climatic conditions, cultural resources, and lifeways of the prehistoric inhabitants of south and southwest Texas.

\section{REFERENCES CITED}

Adovasio, J. M. and R. L. Andrews

1979 Basketry from Baker Cave (41 VV 213). Manuscript on file at Center for Archaeological Research, The University of Texas at San Antonio.

Alexander, H. L., Jr.

1963 The Levi Site: A Paleo-Indian Campsite in Central Texas. American Antiquity 28(4):510-528.

Alexander, R. K.

1970 Archeological Excavations at Parida Cave, Val Verde County, Texas. Papers of the Texas Archeological Salvage Project 19. Austin.

1974 The Archeology of Conejo Shelter: A Study of Cultural Stability at an Archaic Rockshelter Site in Southwestern Texas. Ph.D. dissertation, on file at The University of Texas at Austin.

Andrews, R. L. and J. M. Adovasio

1980 Perishable Industries from Hinds Cave, Val Verde County, Texas. Department of Anthropology, University of Pittsburgh, Ethnology Monograph 5.

Blair, W. F.

1950 The Biotic Provinces of Texas. Texas Journal of Science 2(1): 93-116. 
Bryant, V. M., Jr.

1969 Late Full-Glacial and Post-Glacial Pollen Analysis of Texas Sediments. Ph.D. dissertation, on file at The University of Texas at Austin.

Bryant, V. M., Jr. and D. A. Larson

1968 Pollen Analysis of the Devil's Mouth Site, Val Verde County, Texas. In The Devil's Mouth Site, The Third Season, 1967, by W. Sorrow:57-70. Papers of the Texas Archeological Salvage Project 14.

Carr, J. T., Jr.

1967 The Climate and Physiography of Texas. Texas Water Development Board Report 53. Austin.

Collins, M. B.

1969 Test Excavations at Amistad International Reservoir: Fal1 1967. Papers of the Texas Archeological Salvage Project 16. Austin.

Davenport, J.W.

1938 Archeological Explorations of Eagle Cave, Langtry, Texas. Witte Memorial Museum Bulletin 4. San Antonio.

Dering, J. P.

1977 Baker Cave Plant Macrofossil Report. Manuscript on file, Center for Archaeological Research, The University of Texas at San Antonio.

1979 Pollen and Plant Macrofossil Vegetation Record Recovered from Hinds Cave, Val Verde County, Texas. Anthropology Research Laboratory, Texas AEM University. College Station.

Dibble, D. S.

1965 Bonfire Shelter: A Stratified Bison Kill Site in the Amistad Reservoir Area, Val Verde County, Texas. Texas Archeological Salvage Project Miscellaneous Papers 5. Austin.

1967 Excavations at Arenosa Shelter, 1965-66. Report submitted to the National Park Service by the Texas Archeological Salvage Project.

1970 On the Significance of Additional Radiocarbon Dates from Bonfire Shelter, Texas: Part I. Plains Anthropologist 15(50): $251-254$. 
Dibble, D. S. and D. Lorrain

1968 Bonfire Shelter: A Stratified Bison Kill Site, Val Verde County, Texas. Texas Memorial Museum Miscellaneous Papers 4. Austin.

Dibble, D. S. and E. R. Prewitt

1967 Survey and Test Excavations at Amistad Reservoir, 1964-1965. Texas Archeological Salvage Project Survey Reports 3. Austin.

Dice, L. R.

1943 The Biotic Provinces of North America. University of Michigan Press. Ann Arbor.

Epstein, J. F.

1960 Burins from Texas. American Antiquity 26(1):93-97.

1963 Centipede and Damp Caves: Excavations in Val Verde County, Texas, 1958. Bulletin of the Texas Archeological Society $33: 1-129$.

1969 The San Isidro Site, An Early Man Campsite in Nuevo Leon, Mexico. The University of Texas at Austin, Department of Anthropology, Anthropology Series 7.

Flyr, D.

1966 The Contemporary Vegetation of the Amistad Reservoir Area. In A Preliminary Study of the Paleoecology of the Amistad Reservoir Area, assembled by D. A. Story and V. M. Bryant, Jr., : 33-60. Report submitted to the National Science Foundation.

Graham, J. A. and W. A. Davis

1958 Appraisal of the Archeological Resources of Diablo Reservoir, Val Verde County. Report prepared by the Archeological Salvage Program Field Office, Austin.

Greer, J. W.

1968a 1968 Excavations at Baker Cave in Central Val Verde County, Texas. Notes of file at Texas Archeological Research Laboratory, Austin.

1968b Some Unusual Artifacts from Val Verde County, Texas. Texas Journal of Science 20(2):183-192. 
Haynes, C. V., Jr.

1964 Fluted Projectile Points: Their Age and Dispersion. Science 45:1408-1413.

Hester, T. R.

1971 Archaeological Investigations at the La Jita Site, Uvalde County, Texas. Bulletin of the Texas Archeological Society $42: 51-148$.

1978 Early Human Occupations in South Central and Southwestern Texas: Preliminary Papers on the Baker Cave and St. Mary's Hall Sites. Center for Archaeological Research, The University of Texas at San Antonio.

1979 Early Populations in Prehistoric Texas. Archaealogy 32(6): 26-33.

1930 Digging Into South Texas Prehistory. Corona Press, San Antonio.

1981 Paleo-Indian Occupations at Baker Cave, Southwestern Texas. For festschrift volume for Robert F. Heizer, R. Berger, editor. In press.

Hester, T. R., D. Gilbow, and A. Albee

1973 A Functional Analys is of "Clear Fork" Artifacts from the Rio Grande Plain, Texas. American Antiquity 38(1):90-96.

Johnson, L., Jr.

1964 The Devil's Mouth Site: A Stratified Campsite at Amistad Reservoir, Val Verde County, Texas. The University of Texas at Austin, Department of Anthropology, Archeology Series 6.

Kelly, T. C.

1976 Resolution of the Plainview-Golondrina Problem. Manuscript on file, Center for Archaeological Research, The University of Texas at San Antonio.

Lehmer, D. J.

1960 A Review of Trans-Pecos Texas Archeology. Bulletin of the Texas Archeological Society 29:109-744.

Martin, G. C.

1933 Archeological Exploration of the Shumla Caves. Witte Memorial Museum Bulletin 3. San Antonio. 
Nunley, J. P., L. F. Duffield, and E. B. Jelks

1965 Excavations at Amistad Reservoir, 1962 Season. Texas Archeological Salvage Project Miscellaneous Papers 3. Austin.

Parsons, M.

1965 Test Excavations at Fate Bell Shelter. Texas Archeological Salvage Project Miscellaneous Papers 4. Austin.

Pearce, J. E. and A. T. Jackson

1933 A Prehistoric Rock Shelter in Val Verde County, Texas. Anthropological Papers of The University of Texas I(3). Austin.

Prewitt, E. R.

1966 A Preliminary Report on the Devil's Rockshelter Site, Val Verde County, Texas. Texas Journal of Science 18(2):206244. Austin.

Raun, G. D. and L. J. Eck

1967 Vertebrate Remains from Four Archeological Sites in the Amistad Reservoir Area, Val Verde County, Texas. Texas Journal of Science 19(2):138-150. Austin.

Ray, C. N.

1941 Various Types of $\mathrm{Clear}$ Fork Gouges. Bulletin of the Texas Archeological and Paleontological Society 13:152-162.

Rea, A. M.

1979. The Ecology of Pima Fields. Environment Southwest, Bulletin of the San Diego Society of Natural History 484:8-13. Balboa.

Ross, R. E.

1965 The Archeology of Eagle Cave. Papers of the Texas Archeological Salvage Project 7 . Austin.

Schuetz, M. K.

1956 An Analysis of Val Verde County Cave Material. Bulletin of the Texas Archeological Society 27:129-160.

1961 An Analysis of Val Verde County Cave Material: Part II. Bulletin of the Texas Archeological Society 31:167-205. 
Schuetz, M. K. (continued)

1963 An Analysis of Val Verde County Cave Material: Part III. Bulletin of the Texas Archeological Society 33:131-165.

Scudday, J. F. and C. W. Hanselka

1975 A Preliminary Study of the Vertebrate Fauna of the Dolan FallsDolan Creek Area. In Devil's River: A Natural Area Survey, Part VI:58-75. Division of Natural Resources and Environment, The University of Texas at Austin.

Sellards, E. H.

1952 Early Man in America: A Study in Prehistory. University of Texas Press. Austin.

Shafer, H. J.

1981 Mouth of the Pecos. In Texas Archaeology, T. R. Hester and D. A. Story, editors, Academic Press. In press.

Shafer, H. J. and V. M. Bryant, Jr.

1977 Archeological and Botanical Studies at Hinds Cave, Val Verde County, Texas. Texas A\&M University, Anthropology Laboratory, Special Series 1. College Station.

Smith, G., Jr.

1975 Impressions of Devil's River. In Devil's River: A Natural Area Survey, Part VI:1-3. Division of Natural Resources and Environment, The University of Texas at Austin.

Smith, H., Jr.

1977 The Lift-out Technique: A Prehistoric Living Floor: Phase II. La Tierra, Journal of the Southern Texas Archaeological Association 4(4):20-23. San Antonio.

Smith, J. and M. Butterwick

1975 A Vegetational Survey of the Devil's River-Dolan Creek Area. In Devil's River: A Natural Area Survey, Part VI:36-57. Division of Natural Resources and Environment, The University of Texas at Austin.

Sollberger, J. B. and T. R. Hester

1972 The Strohacker Site: A Review of Pre-Archaic Manifestations in Texas. Plains Anthropologist 16:326-344. 
Sorrow, W. M.

1968 The Devil's Mouth Site: The Third Season - 1967. Papers of the Texas Archeological Salvage Project 14. Austin.

Stock, J. A.

1977 Survey and Testing at Baker Ranch, 1976. Manuscript on file, Center for Archaeological Research, The University of Texas at San Antonio.

Story, D. A. and V. M. Bryant, Jr.

1966 A Preliminary Study of the Paleoecology of the Amistad Reservoir Area. Report submitted to the National Science Foundation.

Suhm, D. A. and E. B. Jelks

1962 Handbook of Texas Archeology: Type Descriptions. Texas Archeological Society Special Publication 1. Texas Memorial Museum, Austin.

Suhm, D. A., A. B. Krieger, and E. B. Jelks

1954 An Introductory Handbook of Texas Archeology. Bulletin of the Texas Archeological Society 25.

Taylor, H. C., Jr.

1949 A Tentative Cultural Sequence for the Area About the Mouth of the Pecos. Bulletin of the Texas Archeological and Paleontological Society 20:73-88.

Voegel in, E. W.

1942 Culture Elements Distributions XX, N. E. California. Anthropological Records 7(2). University of California Press. Berkeley

Weir, F. A.

1976 The Central Texas Archaic Reconsidered. In The Texas Archaic: A Symposium, T. R. Hester, editor:60-66. Center for Archaeological Research. The University of Texas at San Antonio, Special Report 2.

Williams-Dean, G. J.

1979 Ethnobotany and Cultural Ecology of Prehistoric Man in Southwest Texas. Anthropology Research Laboratory, Texas A\&M university. College Station. 
Wooldridge, H. G.

1978 Faunal Analysis, Baker Cave. Manuscript on file, Center for Archaeological Research, The University of Texas at San Antonio.

Word, J. H. and C. L. Douglas

1970 Excavations at Baker Cave, Val Verde County, Texas. Texas Memorial Museum Bulletin 16. Austin. 